\title{
a tonteira e o tropismo
}




\section{sumário}

introdução 5

o filme a mão 25

todos os verbos são no passado $\quad 75$

monaísa 113

branco de sol 159 


\section{introdução}




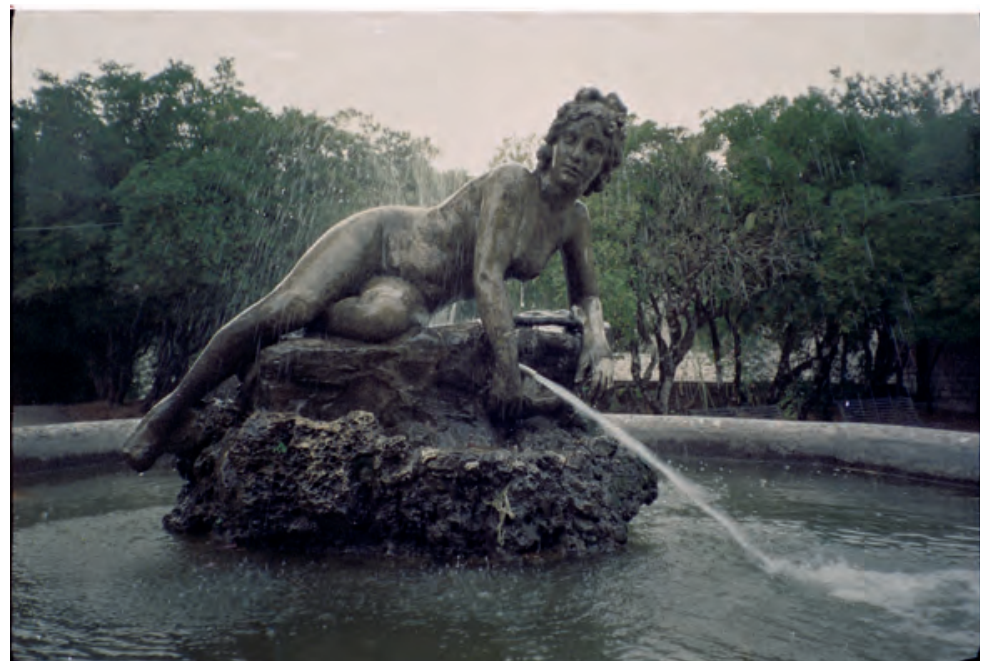




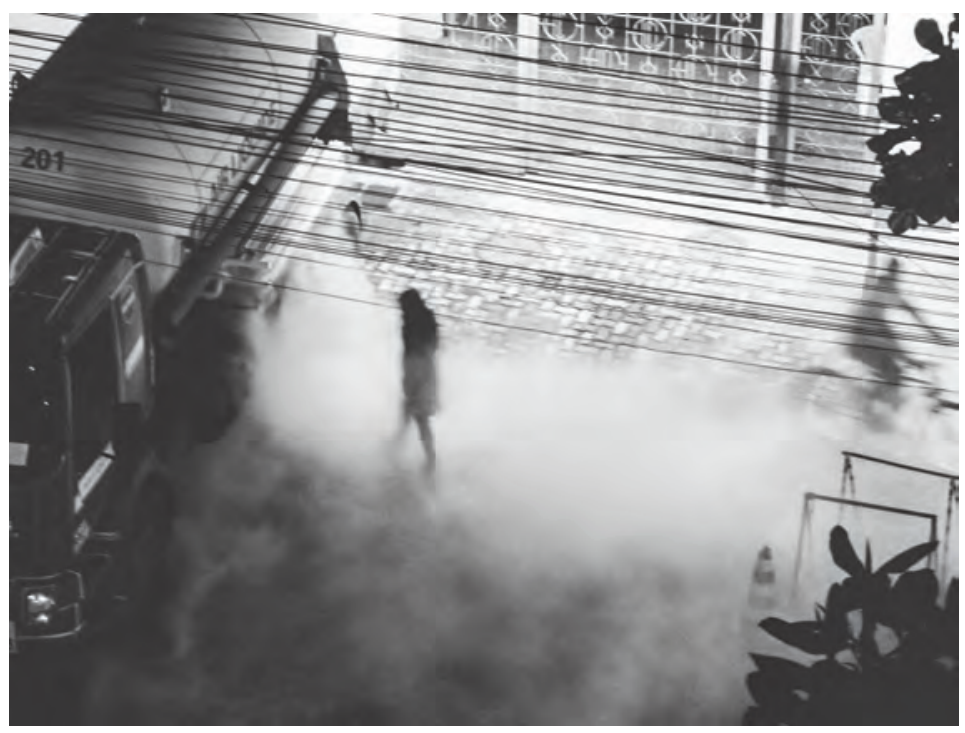




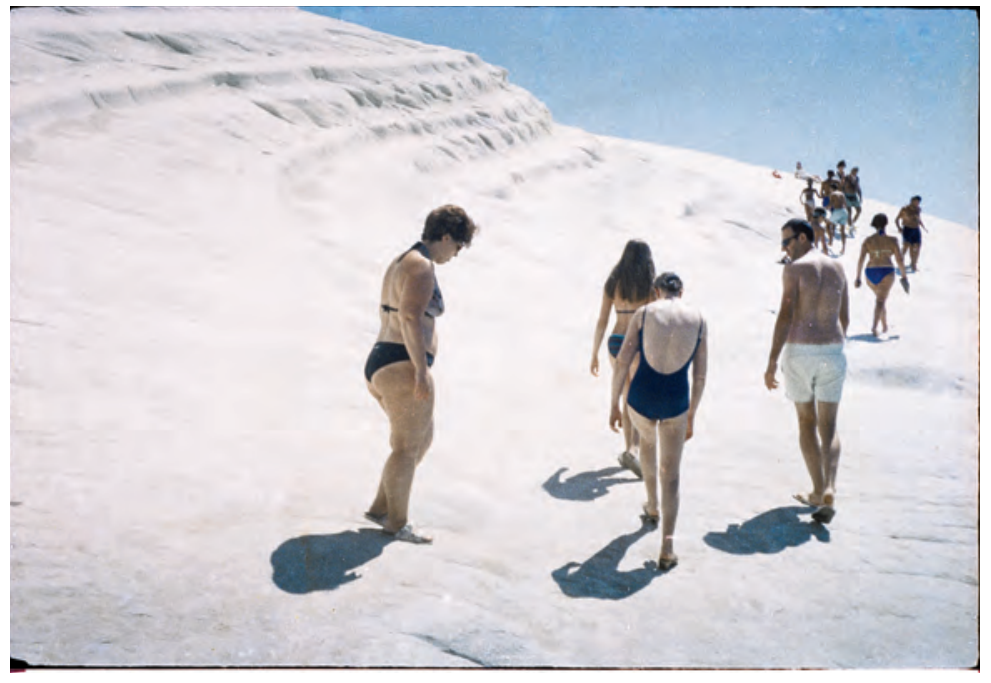




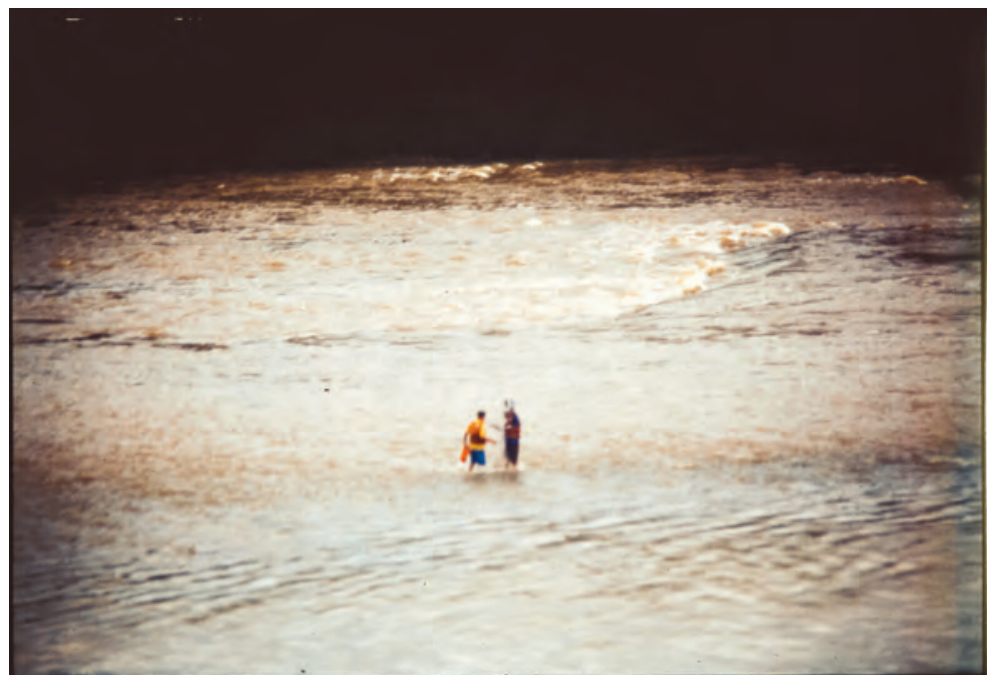




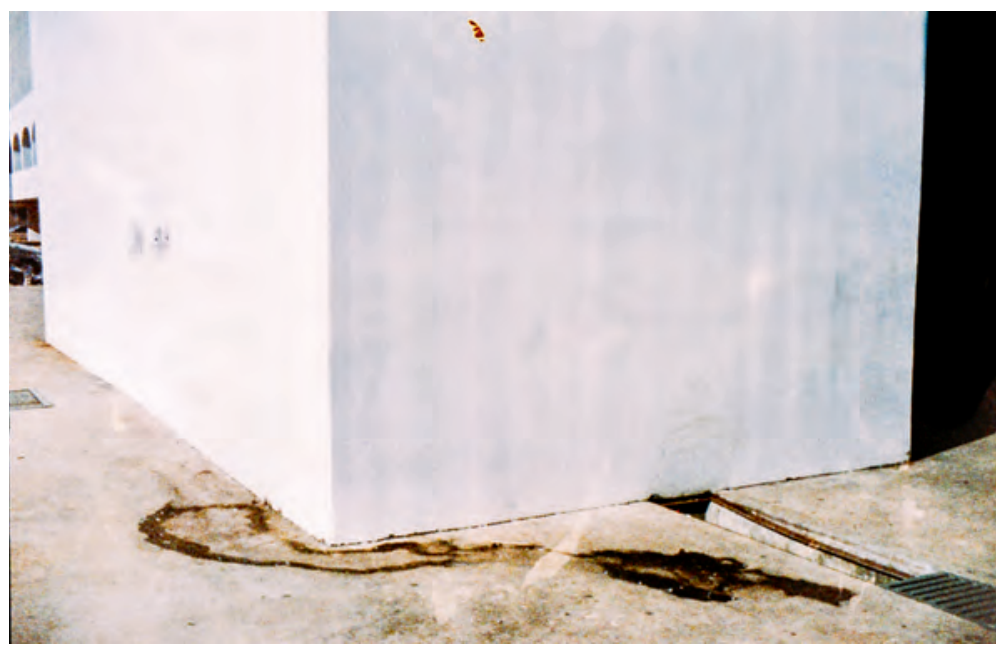




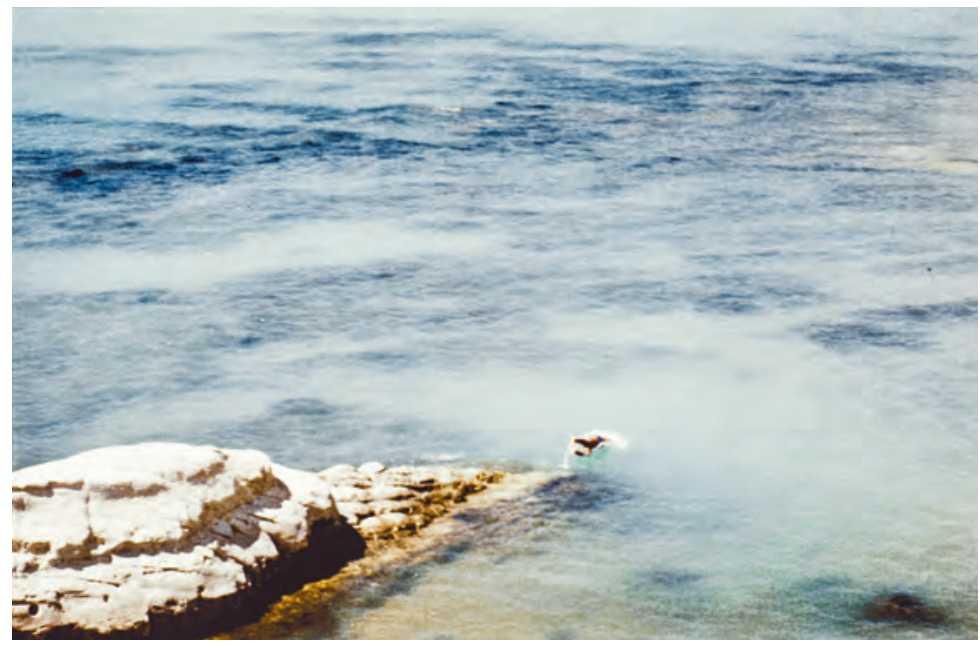




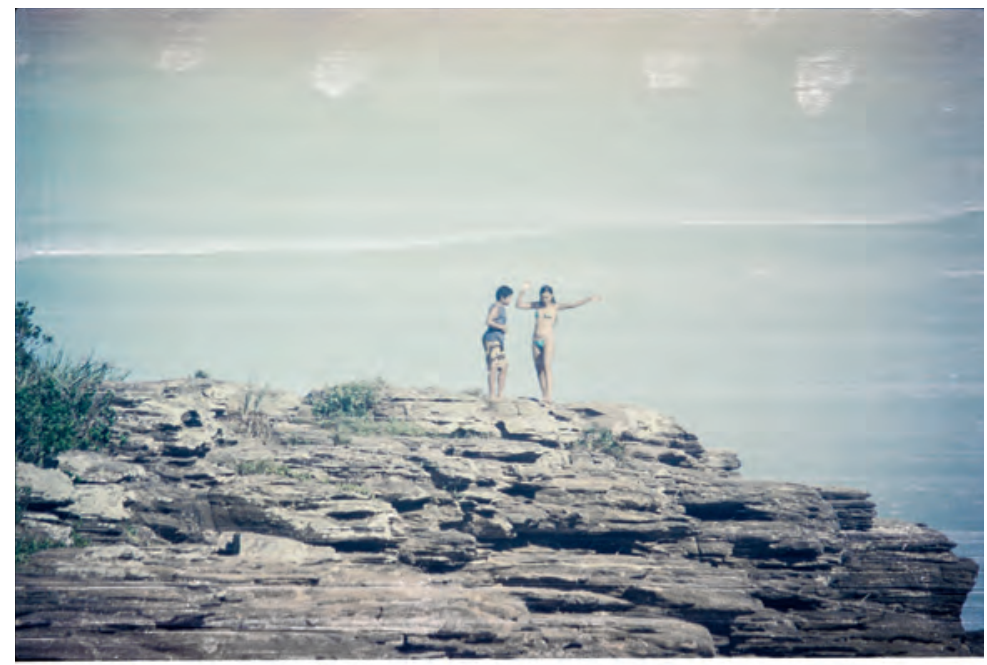




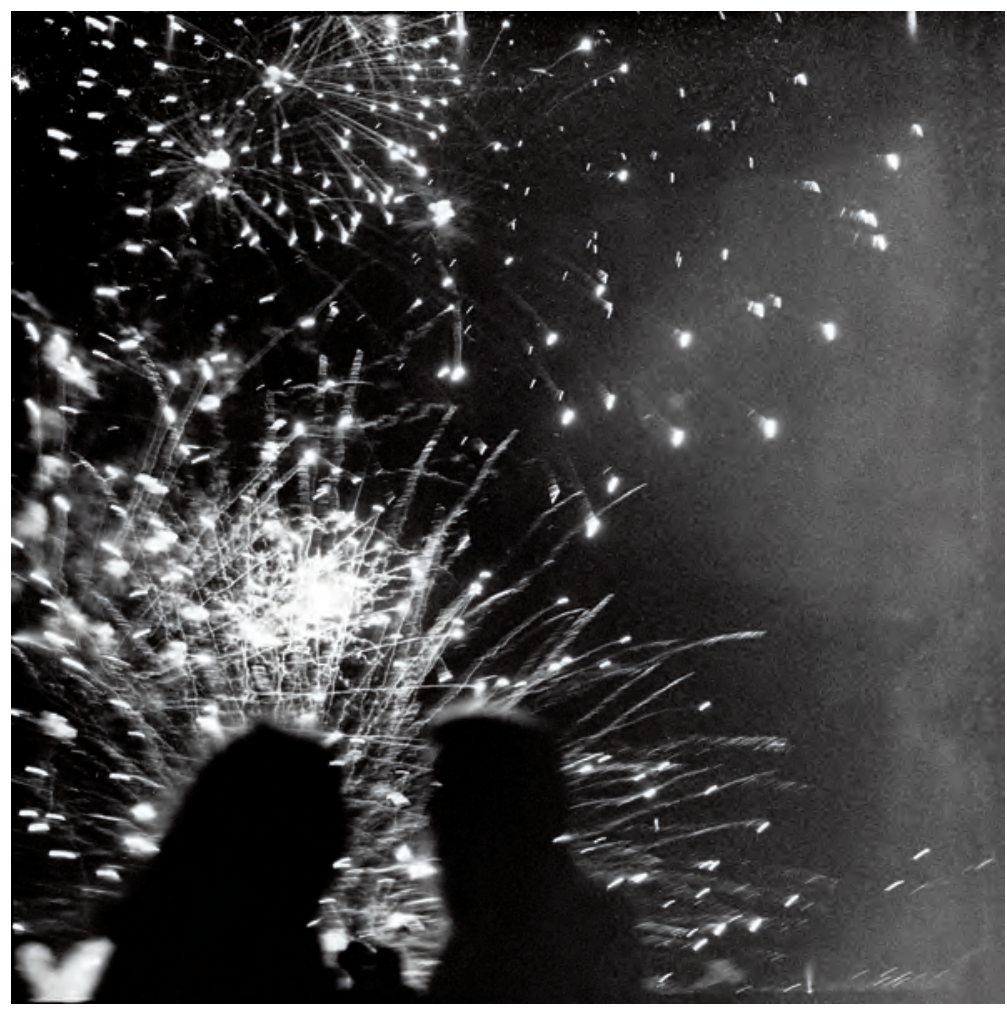




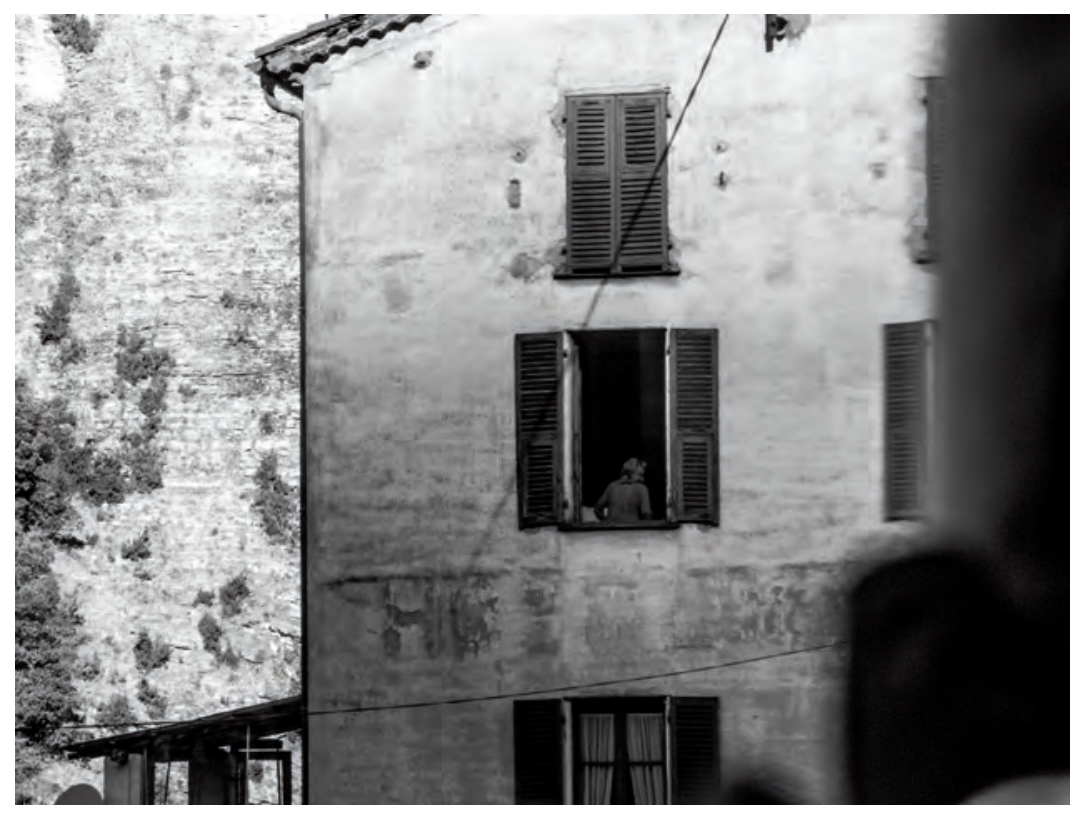




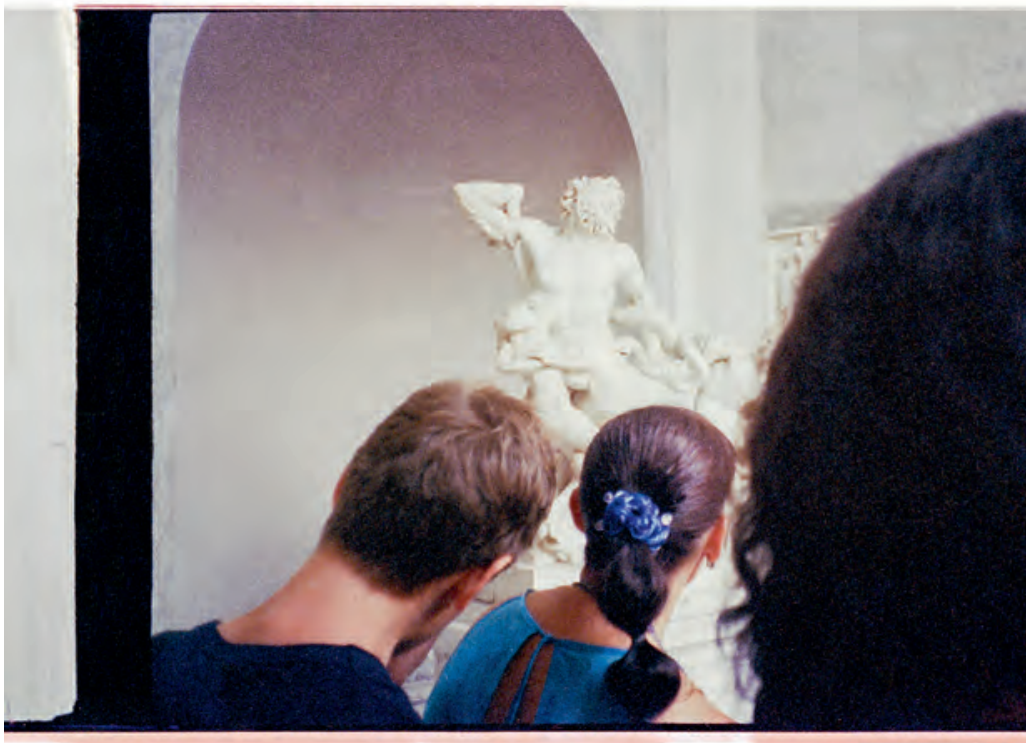




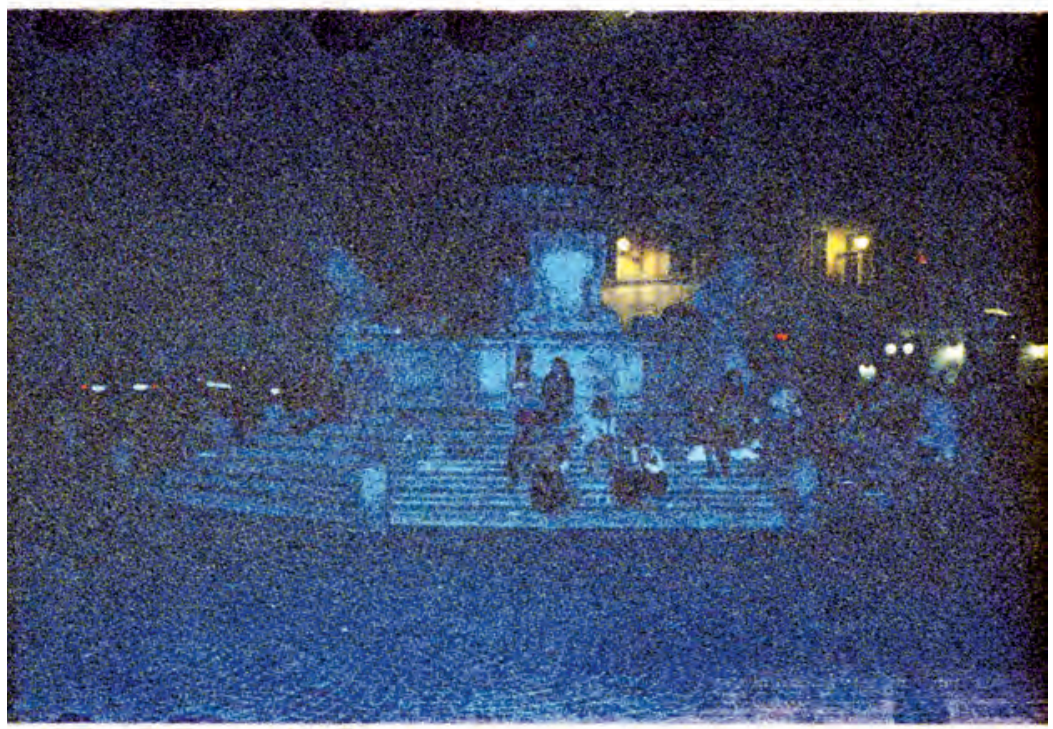




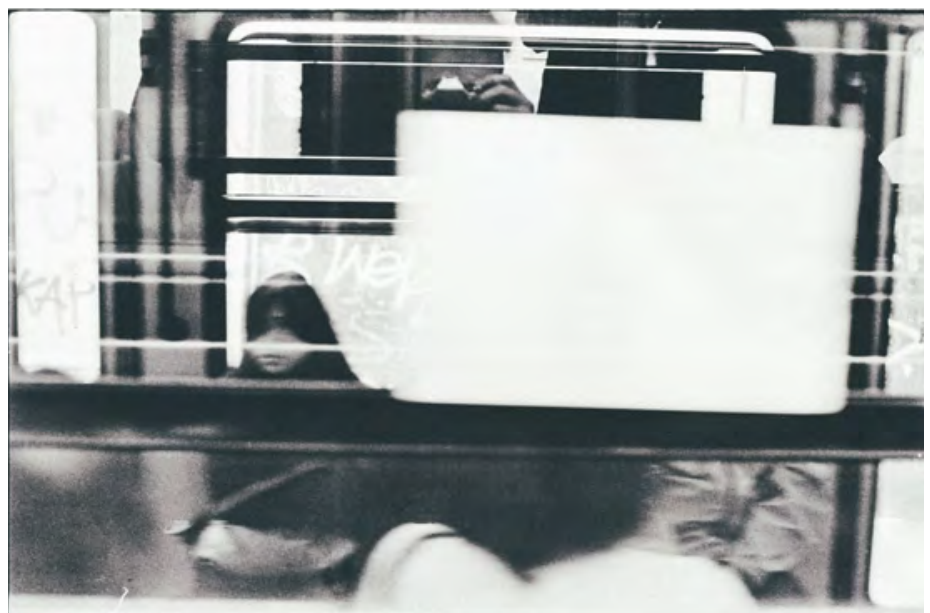




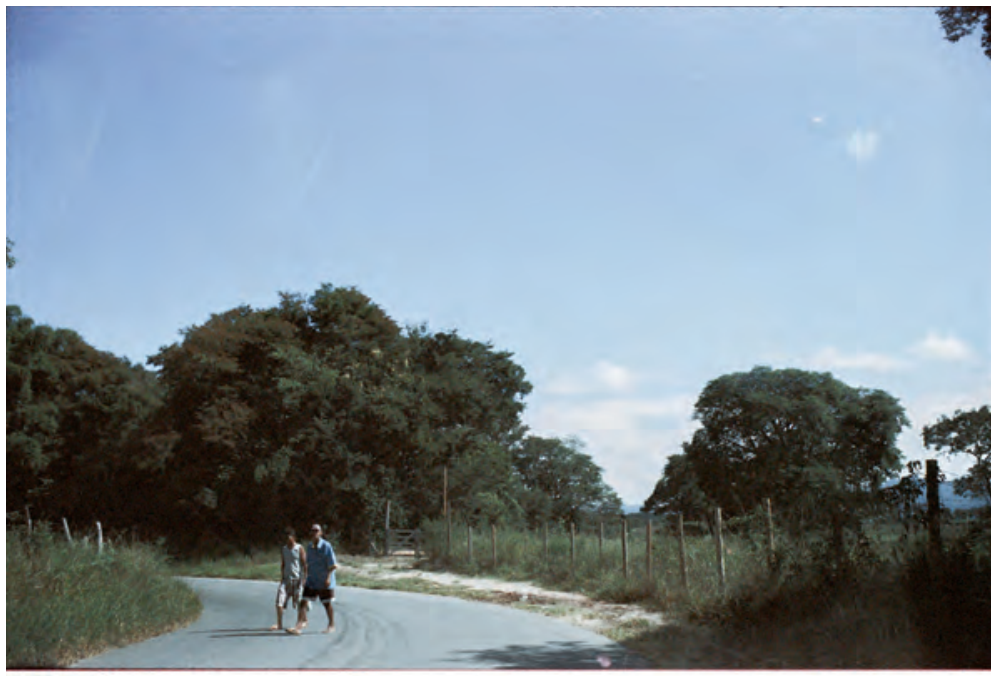




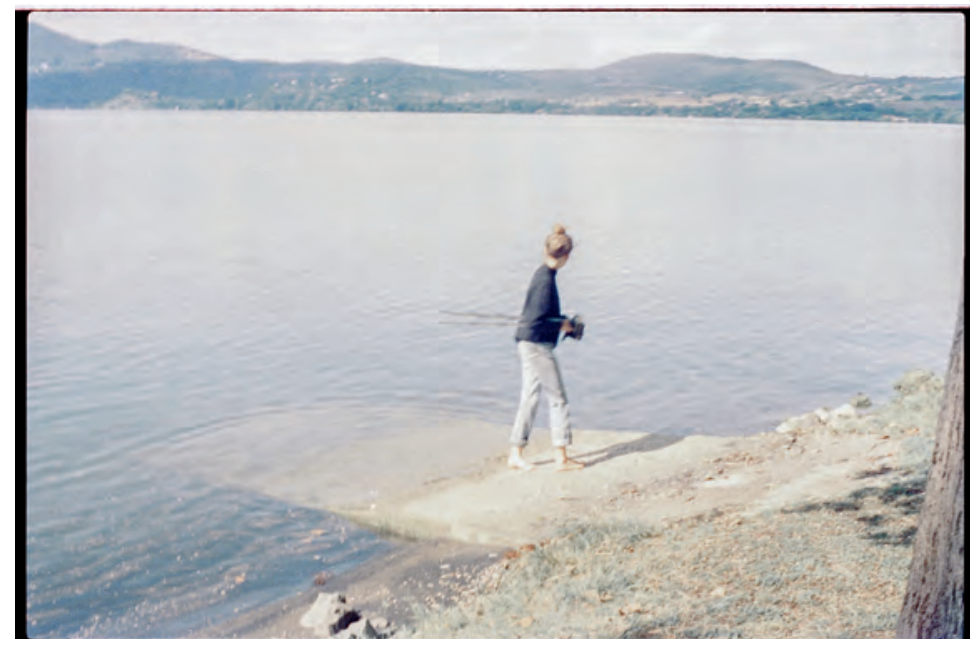




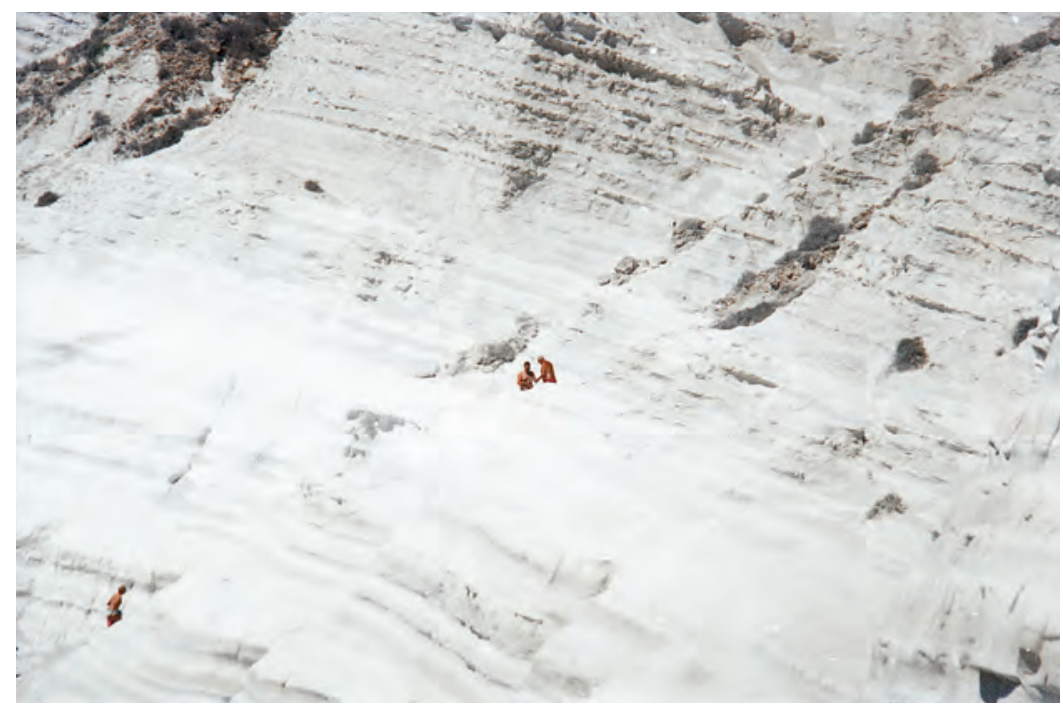




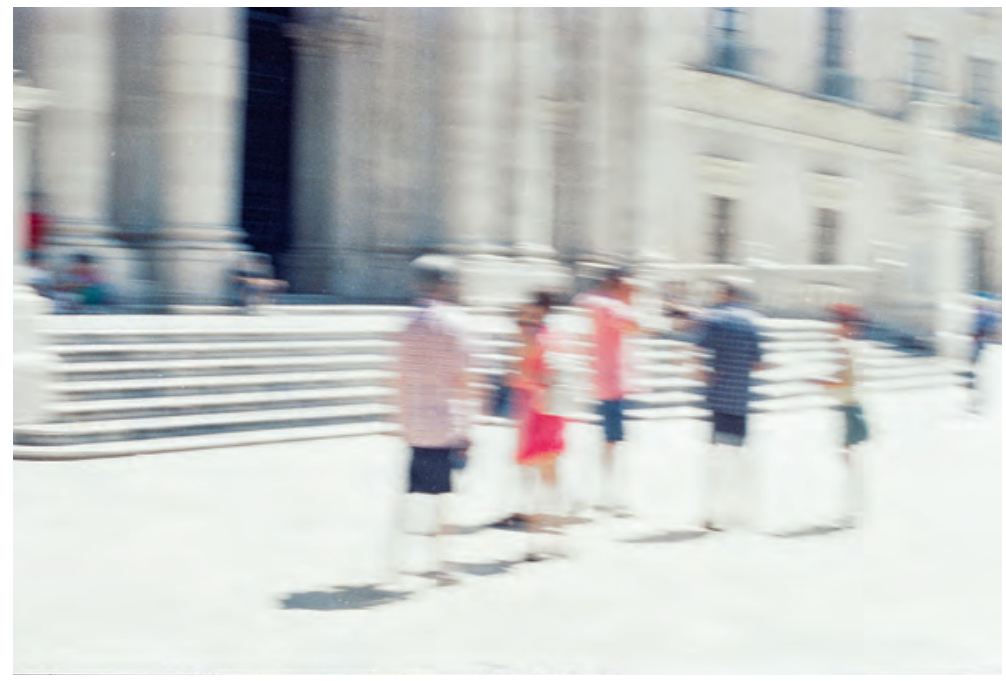




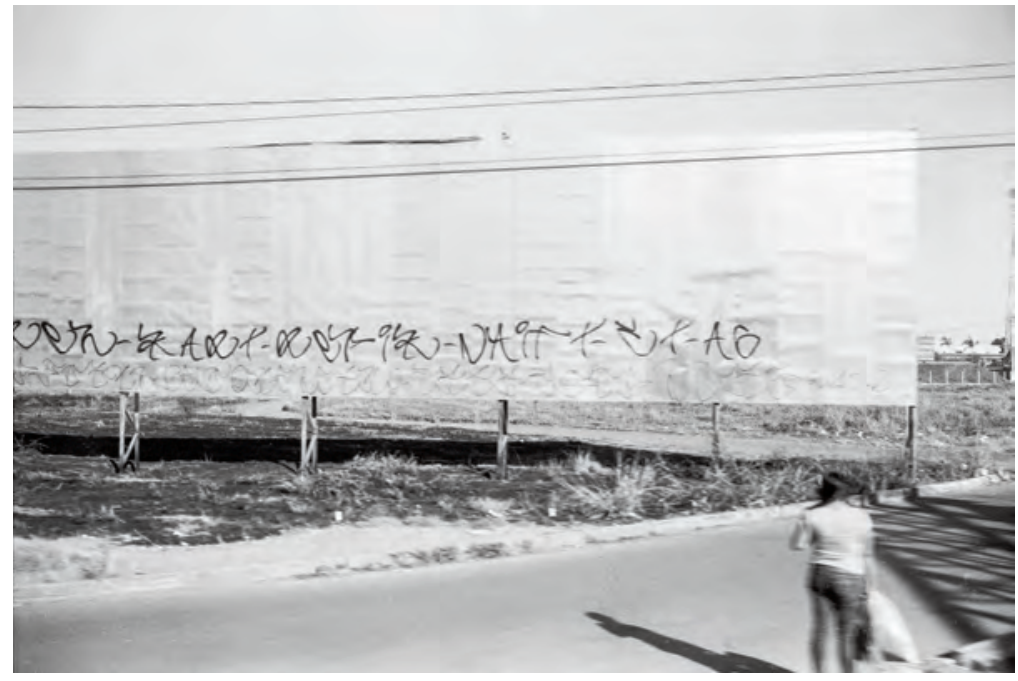




\section{o filme a mão}



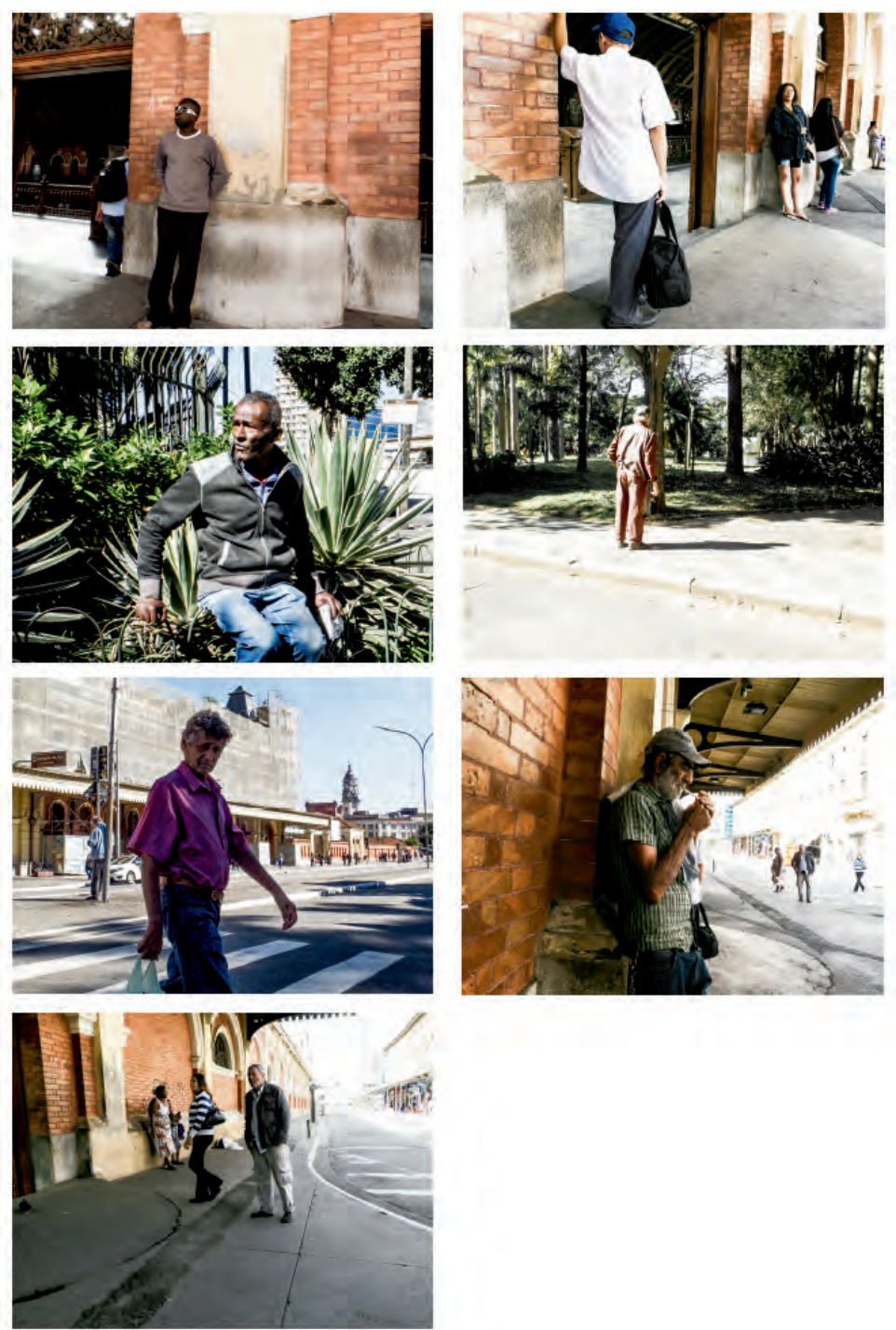

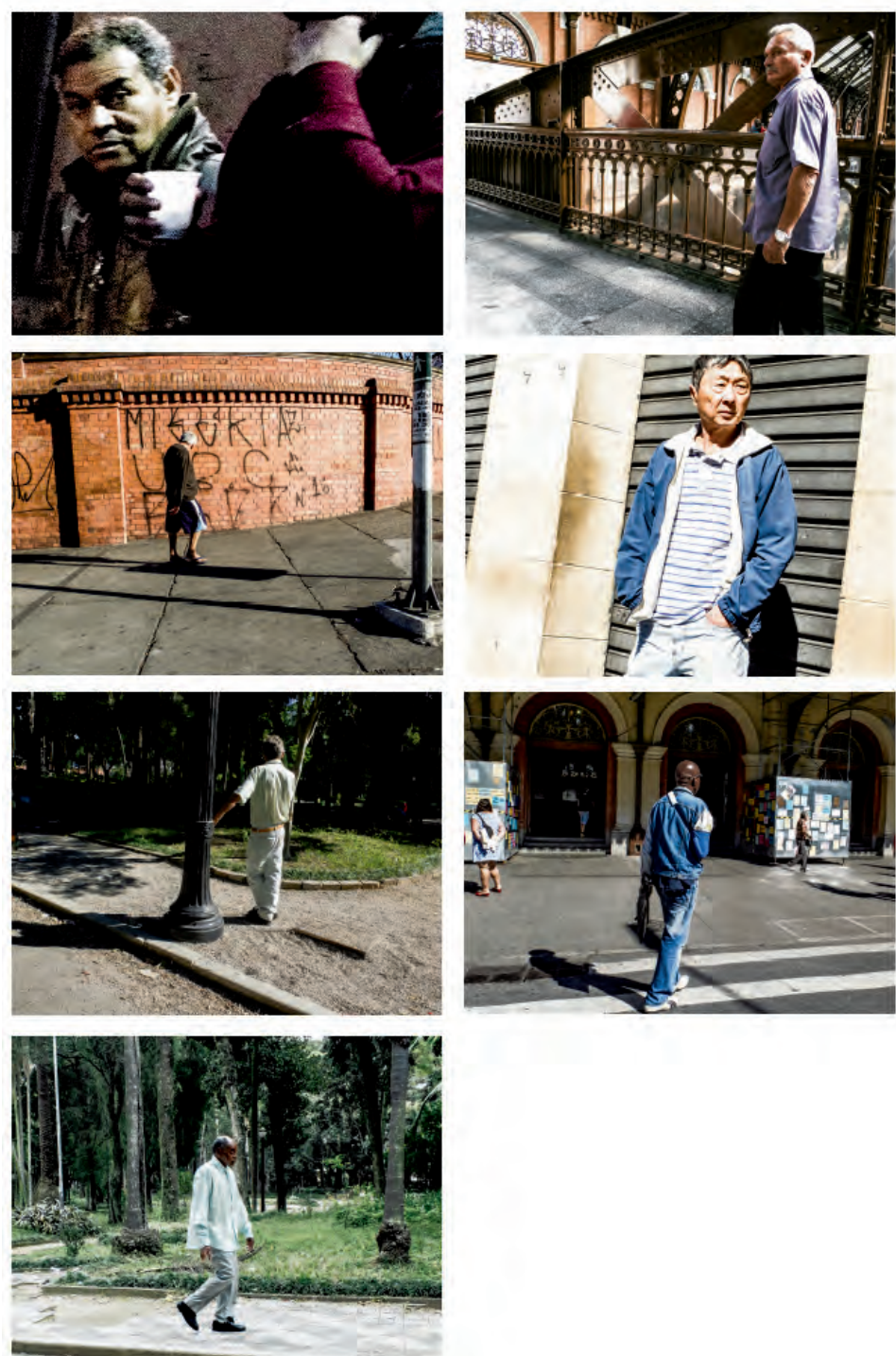
Eu disse por dizer, não era com má intenção.

Você sabe que às vezes, lá no fundinho, existe uma reviravolta entre o que faz bem e mal aos outros na nossa cabeça, não é? Frase no ônibus, 2013 
Estava me preparando pra sair de casa e não era simples. Depois de quase duas semanas sem pôr o pé na rua, afastado do silêncio rumoroso de São Paulo, voltava ao congestionamento corporal nada íntimo das ruas. Isso porque nesses últimos dias recebia alguns amigos e telefonemas depois do meu pequeno surto. Depois de achar que ia morrer no dia seguinte a uma grande festa, também por ser os vinte e sete anos, estava em casa mal tomando café, mal fumando, bebendo pouco ou quase nada só pra cair no sono.

Ia na casa de amigos contar o roteiro que tinha escrito e que eles me pediram pra contar, justo nesse momento, porque não sabiam o que acontecera. São bons amigos, mas críticos e com muitos trabalhos, às vezes coisas importantes das nossas vidas passam batido e não seremos nós a ligar pra lamentar. Quem é esse nós?

Estava tremendo e não sabia o motivo, talvez muito café, talvez porque procurava a chave depois de dias e não a encontrava, e me questionava se deveria tomar um banho ou se ia bem carregar essa angústia visual da olheira, do cabelo sujo, da roupa que eu não sabia distinguir se era o fedor ou uma ânsia que comecei a produzir pelos mínimos cheiros nesses tempos. Na blusa preta um pouco de ranho, mas poderia ser uma gota de molho do almoço que comi no meio do caminho, pensei como desculpa interna. 
Eles poderiam me dar os caminhos de fazer o filme, de compreender algumas coisas da produção que me ultrapassavam, alguns valores do mercado e dos editais dos quais andava por fora nos últimos anos. Era uma possibilidade também de contar esse roteiro que eu mantinha pra mim, uma idéia que se gesta por longo tempo, e vai ganhando uma maturidade, como um bebê que a cabeça não cresce e as sensações ganham mais tempo dentro da barriga. Soube há pouco que ficaríamos um tempo mais por lá, não fosse nosso crânio. Então qual foi esse passo que fez nosso crânio ser o impeditivo do conforto?

Então vejo que a minha mochila, com dezenas de folhas soltas, não traz o roteiro, a mochila que eu preparei, esqueci de colocar o roteiro, o roteiro que tinha escrito, primeiro impresso e depois corrigido e repensado a lápis não veio comigo. O celular com pouca bateria. Ia contar o roteiro, fica mais intenso quando eu conto e depois envio por e-mail pra vocês.

Vários pontos longe de casa, sentado (porque caminhei o dobro do comum, fui até ao ponto final do meu ônibus para ser o primeiro a entrar), chego na região do Butantã, passo o metrô, continuo mais alguns quilômetros pela Corifeu. Chego, subo ruas, chego no portão. 
C. está do lado de fora, se despede de um conhecido, estavam discutindo um trabalho, falaram nomes de câmeras, falaram de dinheiro, também falaram mal de um ou outro governante atual, é como um oi de hoje, relembrar que todos nos dirigimos pra essa indignação que por enquanto é apenas formadora de amizades.

Caminhando, já com sorriso no rosto, sorriso verdadeiro, penso por onde começo o roteiro. Ele já tinha modificações que não podiam vir em dúvidas ou esperando um balanço de cabeça de aprovação ou reprovação. Tantos filmes são feitos pelo balanço de cabeça dos próximos, dos que têm o dinheiro, dos que tem a sala de cinema, esse não? Por que não? Haveria de ser assim, pensei dando oi.

- Ei, como cê tá? Faz um tempo já, desde a casa do X.

- É verdade, vocês andam muito ocupados. Que bom.

- Muito ocupados, mas só escrevendo projetos, trabalhando quase de graça pros outros, enfim.

- Sim, cinema.

- Cê já tomou café?

- Sim, mas tomo de novo, tô até tenso, nunca encontrei você pra contar roteiro.

Essa breve conversa com a C. no portão e o J. vem na sequência, 

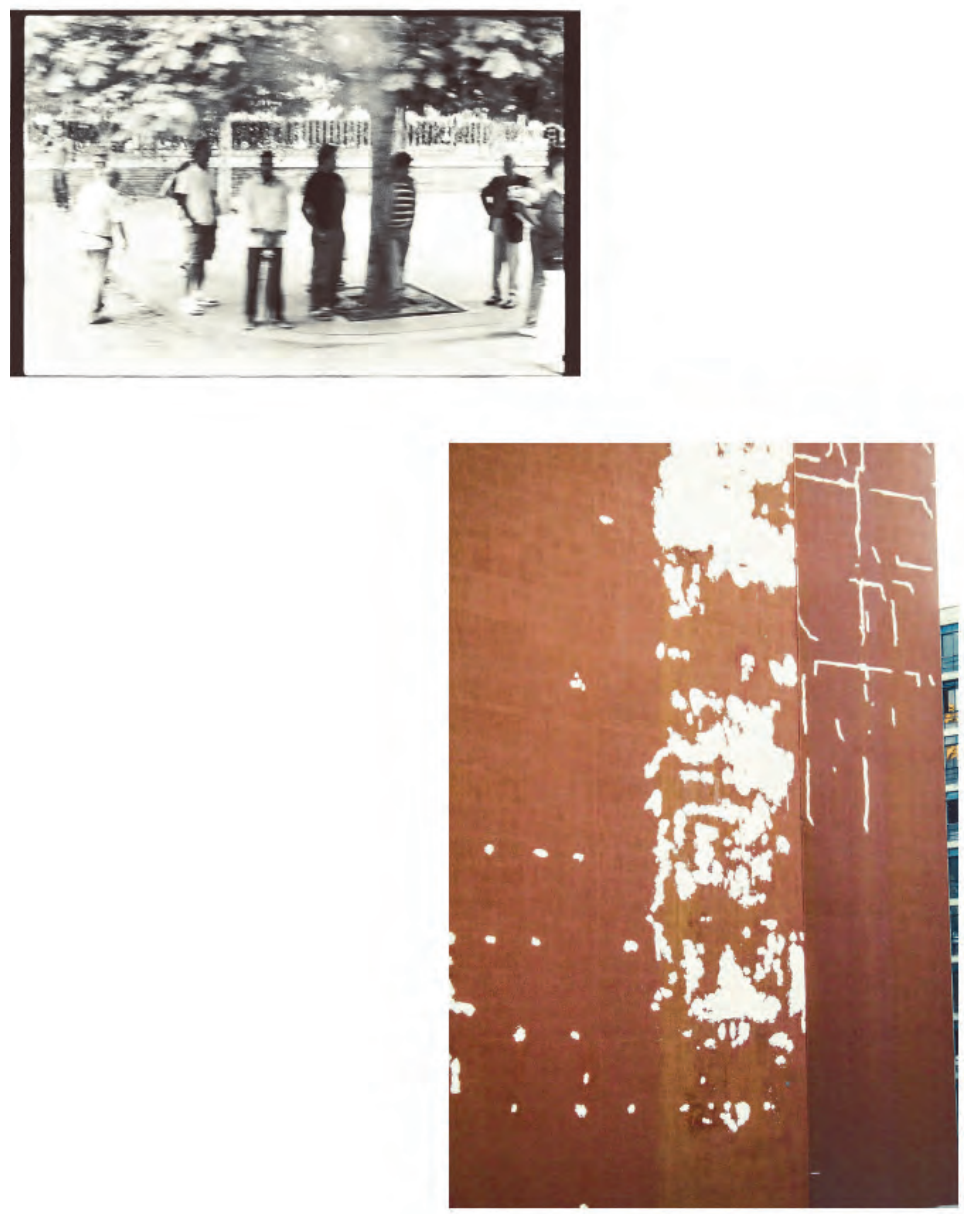
nos cumprimentamos e entramos na casa, era outono, todos saem carregados de malhas de casa, fazem o ciclo do sol entre tirar e pôr, e comentam como o clima de São Paulo é louco, esquecendo que este é o outono dos trópicos, que vem acompanhado, quando o céu está limpo, dos tons de laranja e rosa que impressionam a cada ano. Um pouco como as explosões das nuvens do fim da tarde no verão. Disse um amigo de outro continente: as nuvens daqui são enormes. E eu ri e depois descobri que era verdade.

O café na mesa, aceito o primeiro cigarro depois dessas duas semanas de medo, ainda com medo.

-É muito longo? - eles me perguntam dizendo mais do que isso. - Não, é até rápido porque não gosto de escrever muitos diálogos, então tem vários espaços abertos. Mas eu vou contar, depois envio por e-mail pra vocês. Pode ser?

- Claro, muito melhor.

Me levanto, vou em direção à janela, peço pra abrir um pouco pra fumaça sair, peço desculpas por não ter trazido cigarro, tiro um bombom do bolso e o ofereço colocando na mesa, tomo um gole de café e me preparo pra começar. J. me interrompe:

- Desculpa, L., será que eu posso responder essa mensagem - 
com o celular na mão - antes de começar?

- Claro, estou sem pressa nenhuma.

- Beleza, vou ao banheiro e já volto.

C. sorri pra mim e sai para o outro lado da casa. Meu café já tinha esfriado um pouco. Penso em me resservir mas lembro que minhas recaídas poderiam vir com qualquer intensidade, como num domingo em que, depois de mais copos de café que de hábito, achei que meu corpo ia explodir.

C. volta primeiro, faço o gesto de pegar mais um cigarro, ela diz que não tem problema nenhum, que está acabando mas que podemos comprar mais na banca da esquina. Até me pareceu bom que houvesse pausas durante nossa conversa. J. também volta.

- Vou começar, tudo bem? Podem me interromper a qualquer momento, a qualquer dúvida, vou acabar falando de várias coisas juntas, não um argumento corrido até porque tenho dúvidas tanto de estrutura quanto de produção.

- Claro, vai fundo.

- O filme se chama A mão. Ele se passa todo em São Paulo, quase todo na Barra Funda, perto dos trilhos de trem. Tem esse personagem, o protagonista, ele não tem nome ainda, já foi Xavier, já foi Miguel, acho que agora o nome mais próximo é Salvador, 
é o nome do meu avô, ele faleceu tem um mês e esse roteiro tem alguns encontros com ele. Veio sendo escrito nesses últimos meses da doença dele. Enfim, não sei porque estou falando disso porque no fim das contas é uma ligação só minha essa, não aparece no filme, ninguém está doente, aliás o personagem tem entre quarenta e cinquenta anos. Talvez em algum momento precise fazer um cálculo mais preciso da idade. Ele é turco mas veio para o Brasil com dezessete anos, veio quando teria que começar a trabalhar ou fazer faculdade. Na adolescência, com uns pais que tinham um pequeno comércio que nunca deu dinheiro de verdade, ficou em depressão e era maltratado pela família porque era o único irmão que não ajudava nessa vendinha de laticínios. Maltratado na relação, eles viam nele um problema, um peso na casa. E ele nessa idade já não tinha gosto por fazer muita coisa, estava um pouco jogado e sabia que se continuasse ali precisaria tomar alguma decisão porque era o último ano na escola. Ele gostava de ficar pensando e nisso disseram que ele deveria fazer filosofia, apesar de nunca ter tido nenhum gosto por estudos.

- Calma, você vai filmar isso? - C. pergunta um pouco assustada. - Não, nada disso.

- Ah, desculpa.

- Eu deveria ter dito de começo. Enfim, ele acaba vindo para o Brasil como uma maneira de fugir dos pais, mesmo que de ma- 
neira muito formal. Um tio distante tinha aqui um restaurante ali na região do Bom Retiro, eram árabes, e ele veio já com um emprego. Veio ficar nos fundos, organizando mercadoria. Nessa loja ele passou os primeiros meses, se importou mais que o comum em conseguir falar português, imagino que pra sair das asas da família. E assim foi: quando começou a conversar na rua, largou o emprego e perdeu contato com esse tio. Chegou a trabalhar numa têxtil de outro árabe da região mas saiu do trabalho maldito, sem poder voltar. Nada disso aparece no filme.

- Então por que você tá contando? Brincadeira.

- É só pra aclimatar esse cara. E isso é o final dos anos oitenta entrando nos noventa. Não, já é noventa e três, quatro. Isso porque ele vai indo muito mal aqui no Brasil apesar de nunca pensar em voltar. Acaba trabalhando em vários lugares por pouquíssimo tempo mas é um homem alto, forte, sério, então de começo inspira confiança até simplesmente começar a desandar. Não tem grandes vícios, acaba sempre morando pelo centro da cidade, mora perto do Mercado Municipal, mora na Liberdade, no Glicério, sempre de maneira informal porque nunca teve os papéis necessários para alugar algo em seu nome. Em noventa e sete, então se ele veio em noventa pra cá com dezessete, em noventa e sete tinha trinta anos. Agora ele tem quarenta e quatro. A conta é mais ou menos essa, porque em noventa e sete ele engravida uma mulher. Eles até saíram por um tempo, ela se 

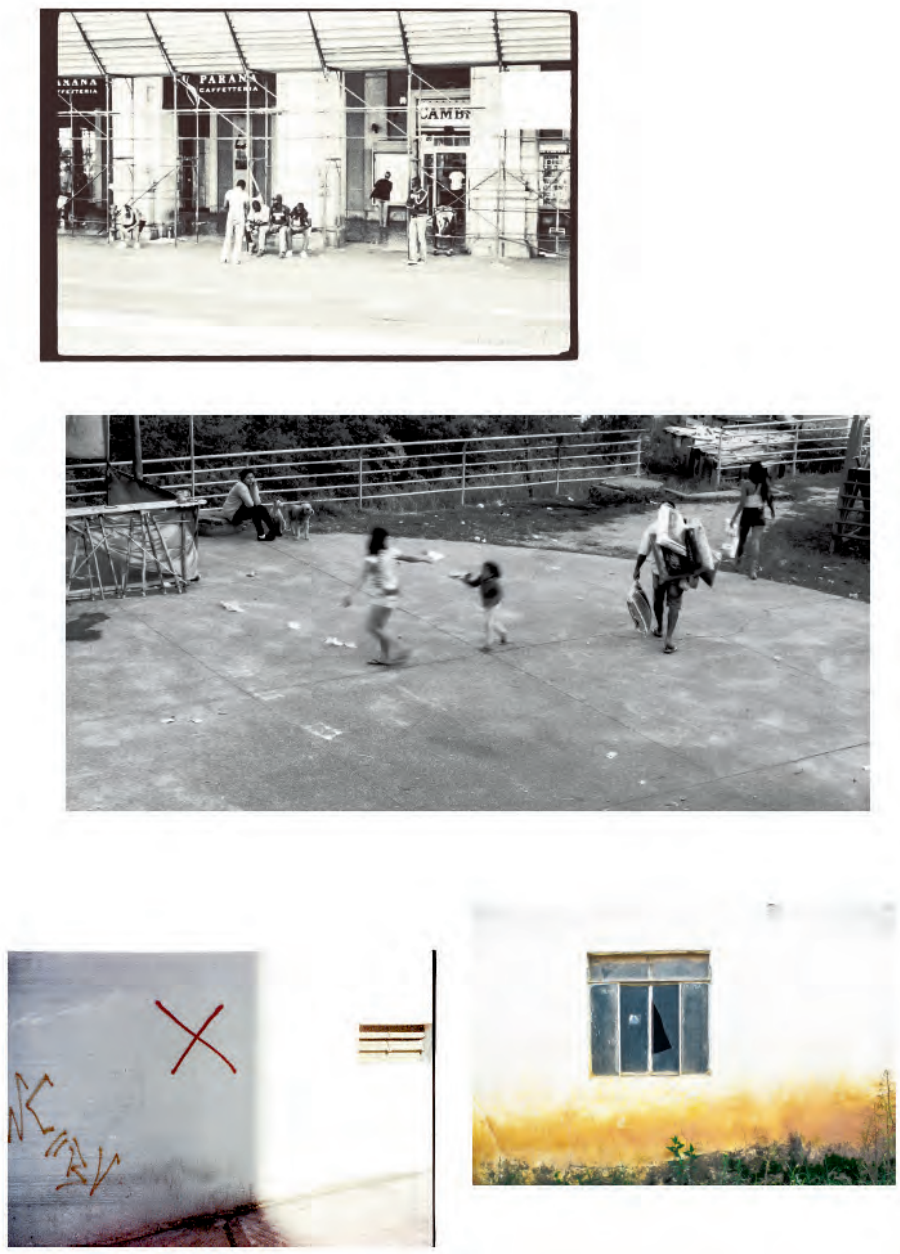
apaixonou por ele, mas não premeditaram nada e ele, aos poucos, durante a gravidez, foi sumindo.

Nada aparece até aqui?

Não, nada.

Eles recebem algumas mensagens no celular, a trilha sonora dessa cena eram as vibrações dos aparelhos, um ou outro bipe, os gatos da rua que miavam de tempos em tempos e uma vizinha ouvindo boas músicas atuais na rádio.

- Seguindo. Nessa época, não sei se tinha uma ligação direta com a gravidez, imagino que sim, ele acabou indo morar numa comunidade na Zona Sul, chegou a passar uma ou outra semana na rua quando dava desencontro entre os pagamentos e o acordo pra ficar num quarto. Lá ficou por algum tempo até ter a ajuda de uma senhora que tinha um filho que trabalhava na Gato Preto, a empresa de ônibus, e que conseguiu pra ele o emprego de cobrador.

- E ele tem amigos?

- Não sei dizer isso, também sinto falta às vezes de que entre ao menos um na história. Mas talvez sejam suficientes os personagens que vão entrar.

- Legal, continua aí. Você quer ir comprar mais cigarro? Acabou de acabar. 
- Vamos lá, só vou terminar tudo que acontece antes de começar o filme, tudo bem?

- Claro.

- Então, ele entra nesse emprego, fica um tempo lá até começar a faltar, a ter os mesmos problemas de depressão e a ver uma falta de sentido completa no trabalho, que sempre batia depois de poucos meses. E esse é o primeiro acontecimento, porque haverá alguns já dentro do filme, que eu diria que ultrapassam a realidade. Um cara da companhia que simpatizou com ele, seria ele que teria o poder de demitir o Salvador, vou chamar assim pra facilitar. Ele resolve um dia conversar com Salvador, saindo da normatividade do departamento de recursos humanos, e no final dessa conversa, tendo entendido melhor as questões-repetições da vida dele, resolve fazer um acordo de nunca trocá-lo de linha, que terminasse sempre o turno dele no último ônibus, ou seja, uma, uma e meia da manhã e isso seria na Barra Funda. Era o bairro que esse funcionário do RH tinha morado na infância, assim como as coisas vão por coincidência, e disse a Salvador para procurar algum lugar ali que conseguisse ter uma vida simplificada, voltasse a pé do trabalho, um pequeno luxo dentro do que é São Paulo. E no fim das contas isso deu bastante certo, e o Salvador tá nesse emprego até o filme.

- Então o filme começa?

- Sim. Antes só essa questão com a filha. Ela cresce, eles têm 
um contato mínimo, especialmente na primeira infância. A partir de uns cinco, seis anos, quando o Salvador já se fixou como cobrador, ele começa a dar cinquenta, cem reais pra essa ex-namorada, Gisele por enquanto, dizendo que é o máximo que ele pode dar naquele momento, explicando a questão dele morar na Barra Funda. $\mathrm{O}$ valor da pensão que um pai deve dar à filha em geral é de um terço do salário. Um cobrador atualmente ganha mil e quinhentos reais, ou seja, ele deveria dar quinhentos reais pra ela. Acontece que ele gasta quase oitenta por cento do salário alugando sua casa, o lugar onde o filme se passa, pelo menos a maior parte do tempo. Então por esses cálculos ele deveria mudar sua forma de vida.

- Então muda pra dar o dinheiro, diz C.

- Sim, ele deveria ou poderia. Mas a Gisele é cristã, e ela aceitou essa condição, mesmo sabendo que isso é um absurdo e nunca o colocou na justiça, mesmo sabendo que ganharia a qualquer momento. Mas agora sua filha, com dezoito anos, no último ano da escola, já pode reclamar por si e isso é uma das questões do filme.

- Entendi, diz C.

- E como é essa casa?, diz J.

- A casa: ele mora perto dos trilhos de trem, ele aluga a casa da Maria. A filha dele também chama Maria. Ele aluga a casa da Maria que é uma mulher de setenta anos que tem essa casa 
de dois andares de herança e aluga o andar de cima, no Rio de Janeiro chamamos de sobrado o andar de cima de uma casa de dois andares, apenas o andar de cima, enfim, ela aluga pra ele esse sobrado, ela cobra muito menos do que ele vale. O Salvador mora lá sozinho, até que é grande, mas é uma casa vazia porque nunca teve dinheiro pra comprar nenhum móvel. Os únicos presentes são os que, ao longo dos anos, Maria foi subindo pra casa dele quando queria comprar um novo, fossepor gosto, fosse porque estava já meio estragado, ou porque considerava necessário tal ou tal móvel na casa de Salvador e isso virava o motivo de sua nova aquisição.

Levanto, olho mais uma vez a caixa de cigarro:

- Vamos lá comprar mais?

Nos levantamos, J. vai colocar mais água pra ferver para o café:

- Tudo bem se forem só vocês dois?, diz J.

- Posso ir sozinho, se quiserem, eu digo.

- Não, vamos lá, diz C.

Andando pela rua:

- Esse bairro daqui tem várias casas como as que eu penso, de dois andares, mas que são dois imóveis separados.

- Até tem, mas a maioria é uma casa só.

- Você lembra da minha casa na Lapa? Quando eu penso o filme é lá. 


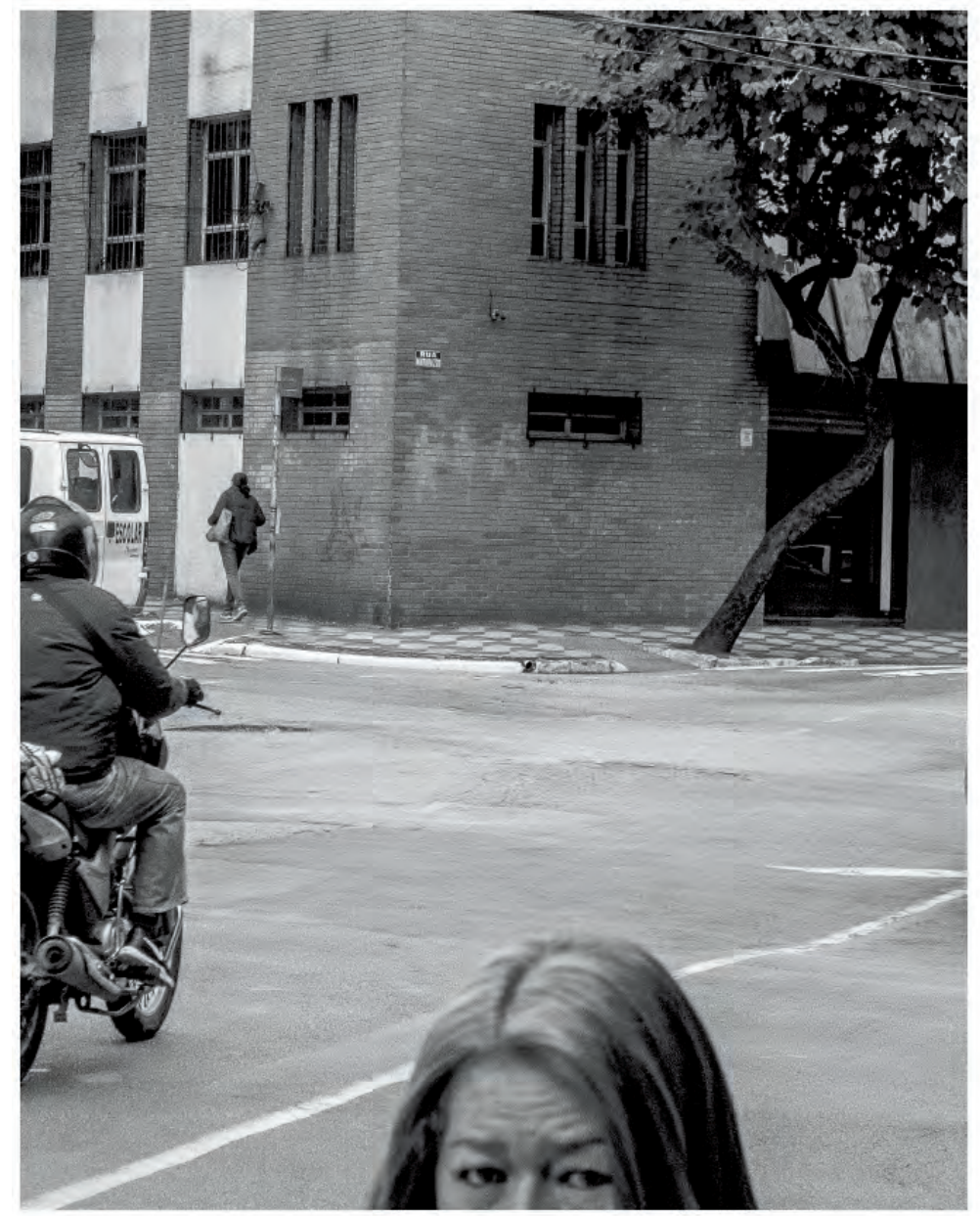


- Sim, eu imaginei que era lá quando você começou a contar. Você conheceu os vizinhos debaixo de você? Você morava em cima, né?

- Sim, mas nunca os conheci. Quer dizer, eu sabia quem eram mas nunca trocamos muitas palavras, também morando com o D., que fazia umas festas imensas, ficou difícil de manter uma boa relação com qualquer um, da frente, debaixo, dos lados. Você tava nas vezes que deu polícia?

- Não, mas fiquei sabendo.

- O R. quase foi preso, enfim. Não era exatamente legal mas parecia tudo meio controlado, a vizinha que mais reclamava a gente não gostava, então as coisas iam sendo tocadas sem o que dá pra chamar de política da boa vizinhança.

Voltamos com o cigarro, J. com o café, trocamos de mesa. Era já próximo do meio dia, sentamos numa mesa na varanda, meu nariz estava entupido todos esses dias, era o final de uma sinusite e, quando fiz a tomografia na cabeça, apareceu como um detalhe: maçã do rosto com massas de secreção.

O sol fez meu nariz escorrer enquanto retomava o roteiro:

- Então, só voltando. Ele dividia essa casa, cada um com seu apartamento, um em cima e o outro embaixo, com a Maria. Ela, 
quando adolescente, participou da luta contra a ditadura, tinha dois irmãos mais velhos que a colocaram em movimentos de resistência, chegou a fazer parte de um grupo considerado terrorista, foi presa, torturada, guardava marcas que até então nunca mostrou para Salvador, pensando agora isso pode ser um tipo de cena de intimidade dentre os diálogos que eu não escrevi. Se casou, nunca teve filhos e acabou virando de direita no plano da macropolítica. É um pouco confusa mas afirmativa. Imagino uma pessoa que guarda uma perspectiva de esquerda nas relações que tem, por exemplo o baixo preço que cobra dele no aluguel, o jeito que ela acolhe a filha do Salvador nas poucas vezes em que ela aparece na casa pra visitar o pai. Essa distinção já quase irreconciliável entre ser de esquerda propriamente e a posição na macropolítica, em que nenhum voto que se transforme em candidatos elegíveis será um voto sem concessões, do mundo do possível. Ela é bastante afetuosa. E essas questões de política não entram diretamente no roteiro. Acho que acabei o preâmbulo.

- Então o roteiro.

- Sim, o filme começa com Salvador fazendo o percurso entre o Terminal Barra Funda e sua casa, já de madrugada. Ele carrega na mão um saco de papel com um salgado, uma esfiha, e caminha pelas ruas. Já pensei que essa história poderia ser contada como um curta metragem, ela se assemelha ao formato do conto, mas 

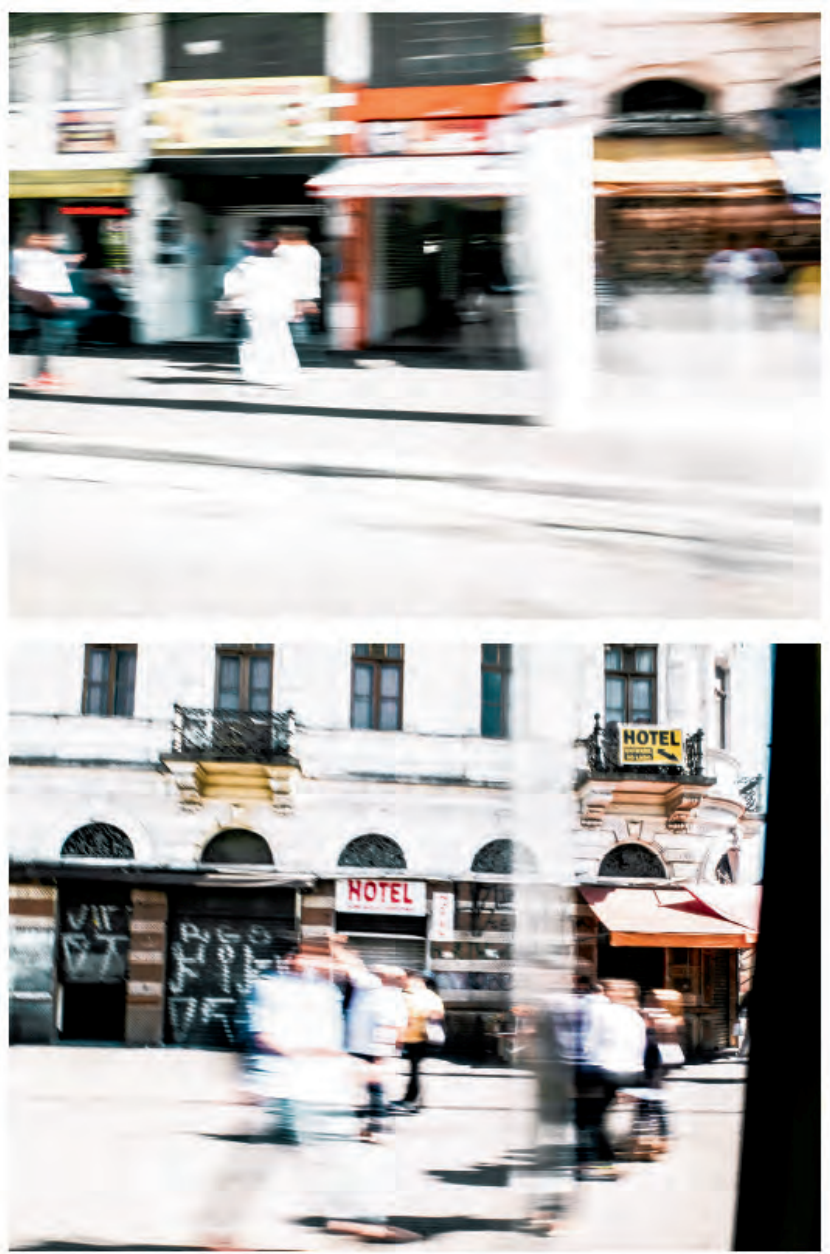
a palavra que me vem à cabeça quando visualizo as imagens é processo. Queria conseguir filmar trazendo uma espécie de possibilidade, transformar o filme em um método. E para construir a coragem, a ética ou a falta dela, é preciso dilatar os tempos, compreender que houve dúvida e que não foi uma virada de cabeça para o horizonte, com a câmera vindo em sua direção, como propõe o insight hollywoodiano, o que desenrolou a trama. É preciso tempo, é preciso filmar o receio mas ver que houve um vôo na sorte e no azar, só possível através das experiências duras vividas. Vividas por Salvador, que não decido ser herói ou anti herói. Nenhum dos dois. Ele não é um modelo, longe disso. Mas gostaria que houvesse qualquer coisa de exemplo em sua aventura.

Então pra essa primeira cena vejo ele fazendo uma boa parte do caminho, andando pelas ruas escuras e vazias, cruzando quem estiver na calçada no momento da filmagem, passando por um boteco ali da região que já tomei cerveja uma ou outra vez.

J. me interrompe mais uma vez por precisar atender uma ligação. Conversamos sobre voltar pra dentro por conta do sol, sem sombra, será que eram as fungadas que eu dava para conter o catarro? J. de volta, ficamos no sol. 
- Ele voltando pra casa, cruzando especialmente os sons da noite, incorporar a realidade da madrugada do bairro, até que já perto de casa ele encontra, jogado na rua, um raio-x. Ele se abaixa, pega esse raio-x, coloca contra a luz do poste e vê uma mão sem três dedos, como que cicatrizando de um acidente. Ele passa um tempo olhando, fica com a chapa e segue pra casa. Chegando lá ele entra na casa da Maria. Ela está dormindo no sofá, está passando um filme desses da madrugada na televisão. Ele desliga o aparelho, vai na cozinha, pega um prato, coloca um pouco de azeite, um pouco de sal e limão. Toma um copo d'água e sai da casa dela entrando na porta ao lado, sua porta, e subindo as escadas. Vemos sua casa pela primeira vez. $\mathrm{Na}$ sala ele tem apenas uma mesa redonda - essa, como todos os outros móveis da casa, como eu disse doados pela Maria, fazem a casa ter um ar de vazio, mas não sei exatamente se traz algo de provisório. Talvez fosse importante que não, que conseguisse mostrar que isso já virou o padrão. Ele coloca o raio-x em cima da mesa e come a esfiha em pé mesmo, molhando alguns pedaços no molho que criou no prato. Essa é a primeira cena do filme. Enquanto come, olha a chapa e desliza os dedos por ela, tentando tirar a poeira da rua. - Você vai contar todas as cenas?

- Mais ou menos. Na verdade a partir daí vemos o decorrer dele, a partir dessa imagem recolhida. A imagem e ele, em contato, criam a idéia dele e do filme: depois de uma tela preta mais demo- 

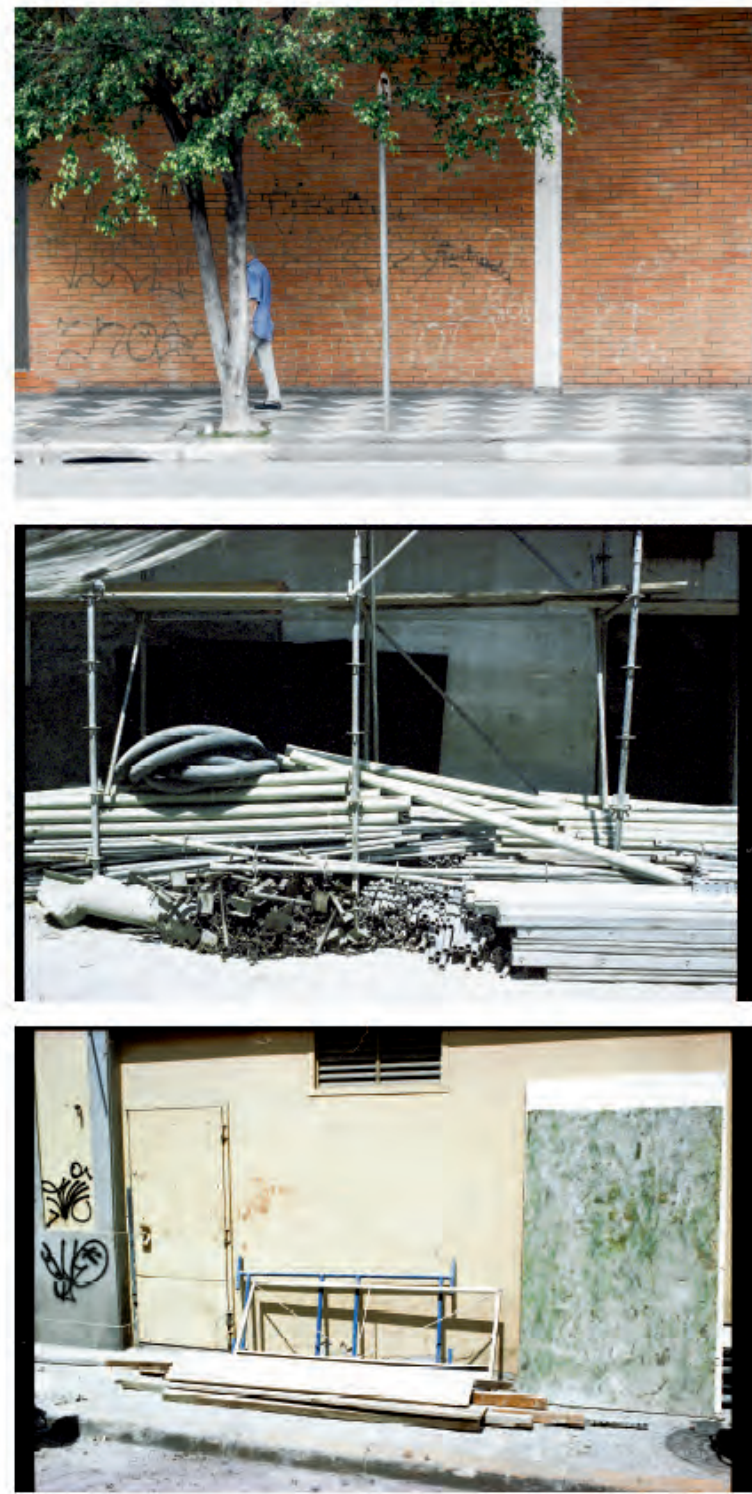
rada, vemos ele chegando no trabalho no dia seguinte, de novo com um saco de papel comendo outro salgado e com um café na outra mão andando por dentro do Terminal, indo em direção ao ônibus. Lá ele encontra o motorista e uma colega fazendo a faxina. Eles tem um rápido diálogo, o Salvador e o motorista tomando esse café da manhã rapidamente, conversando com a mulher sobre as coisas que as pessoas esquecem no ônibus. Ela mostra para os dois tudo o que ela carrega no corpo que foi esquecido no ônibus, os brincos dela, a malha por baixo do uniforme, mostra até o celular e o fone e ninguém discute se isso é lícito ou não. Eles riem mas olham pela janela. Tem algo assim do humano, ou do brasileiro? Rimos e olhamos para o outro lado quando somos contrariados, mas longe de ser suficiente uma intervenção ou até mesmo quando nós mesmos sabemos ser errado legalmente, mas ainda pairamos entre a justiça com letra maiúscula e a com letra minúscula. Segue a sequência com conversas entrecortadas entre Salvador e o motorista e as pessoas entrando no ônibus num longo trajeto. Nesse mesmo dia, já em casa, de madrugada, ele olhando a foto tem a idéia que move o filme: ele vai fingir que perdeu sua mão, ou melhor, vários dedos, pra pedir uma aposentadoria por invalidez. Ele vai simplesmente esconder a mão num curativo que vai, a cada dia, melhorando, sendo aperfeiçoado, ficando cada vez mais verdadeiro e vai fazer os procedimentos para pedir essa invalidez. 

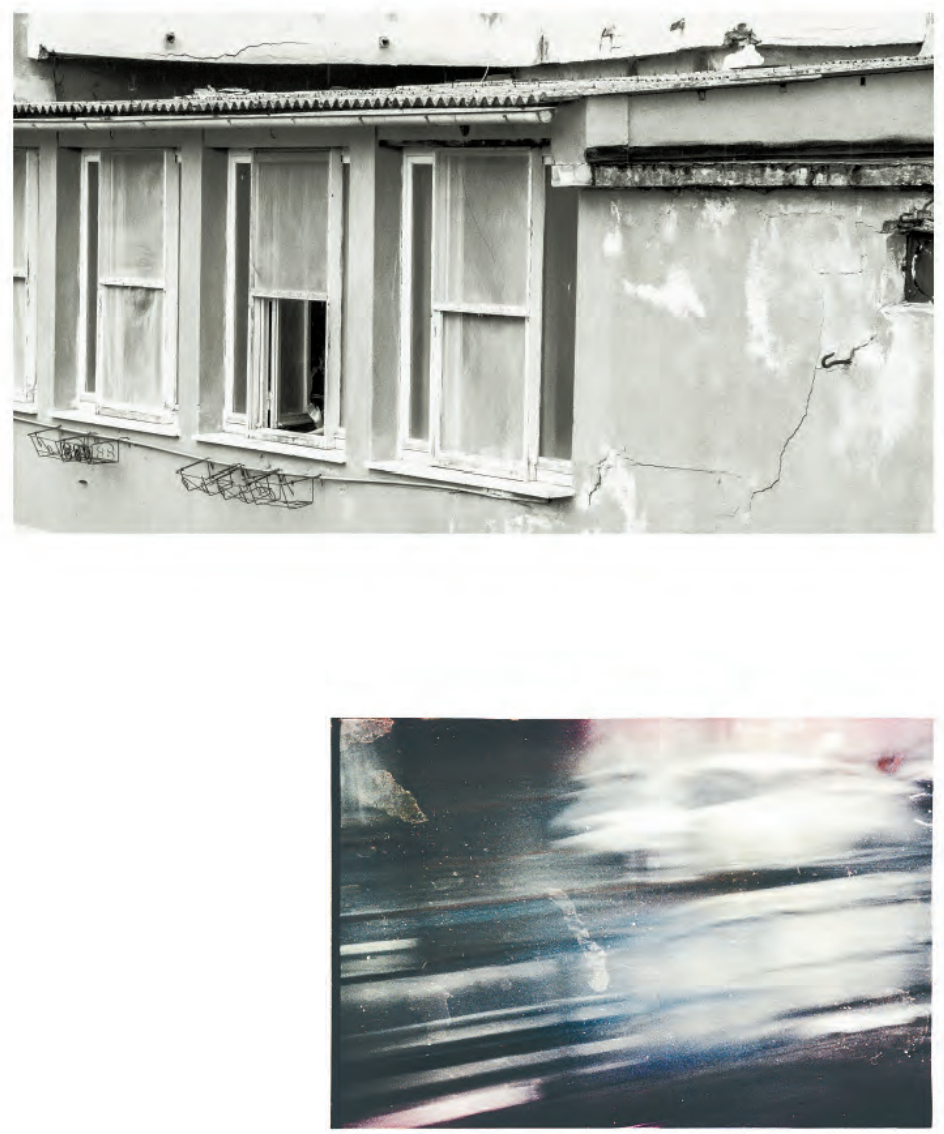
- E isso encaixa com esse personagem? Digo, ele tem essa falta de ética e encara essa situação? Até pensando em coragem mesmo, C. faz esse comentário já quase descrente do personagem. - Talvez aí seja uma das partes desse roteiro que se desvincula do real. Acho que esse filme tem um otimismo desgastado. Por muito tempo, quando via filmes que propunham um realismo, naturalismo, essas palavras que ficam confusas no cinema, e que terminavam com um final triste, da degradação, de como a vida de fato pode ser trágica para muitos, pelo caminho da depressão, das dificuldades absurdas do que nasce num lugar marginalizado, me batia uma sensação de que não fazia muito sentido manter uma proposição ampla do real. Claro que estava olhando para a minha produção e não para o que o cinema devia ou não devia ser. Nesse roteiro, que ainda quero continuar contando pra mostrar os encontros entre o absurdo e o cotidiano, quero me debruçar na lógica do processo, para que o inverossímil ganhe a potência de criar uma imagem do que sabemos impossível: improvável? Todas as indagações dos que assistem, sobretudo nesses pontos que você marcou, coragem, ética e mesmo a possibilidade dessa pequena loucura dar certo aqui e agora, é que trazem o lado reflexivo do filme. É como lidar com o e se... que em geral fica no campo da idéia, no máximo de conversas ditas infrutíferas que tenho vontade de desdobrar em imagens. Lembro de ir ao cinema ver com um amigo um filme ruim, mas que tinha ganho vários 
prêmios desses importantes, internacionais, Berlim acho. Era um garoto iraquiano que vivia na França e tinha seu grande amor na Inglaterra. No filme ele aprende a nadar com o objetivo de atravessar o Canal da Mancha a nado, já que ele era um refugiado e não poderia cruzar a fronteira legalmente. Não lembro direito do fim, mas me parece que ele não consegue. Acho que esse é um filme que consideram filme cult ou alternativo, essas classificações que só melam os filmes. Acho que tudo isso é pra dizer que existe uma outra coisa entre a desgraça do filme, que aponta para os problemas do mundo, e a desgraça que é Hollywood, farsa de um mundo possível. Aos poucos todos estamos percebendo que não adianta comprar a chuteira do Cristiano Ronaldo pra jogar bem ou ficar rico, e que as histórias de superação vividas na montagem dinâmica do bem e do mal só alimentam uma outra imagem, uma imagem acorrentada na outra. Mas existe algo nesse ínterim, entre a farsa e o realismo, que expurga a imaginação. Naquele filme citado do Canal da Mancha, lembro de sair da sala de cinema conversando com esse amigo e falávamos em ver algo absurdo acontecer, não porque o filme foi triste, mas pra que pudéssemos ao menos nos irritar com profundidade, e nesse processo designar novos sentidos na irritação ou no deslocamento do que compreendíamos possível. Essa falsificação em imagem coloca o verossímil equilibrado na lâmina, e aturde o discurso frente ao imaginário. Todas essas idéias podem ser mal vertidas 

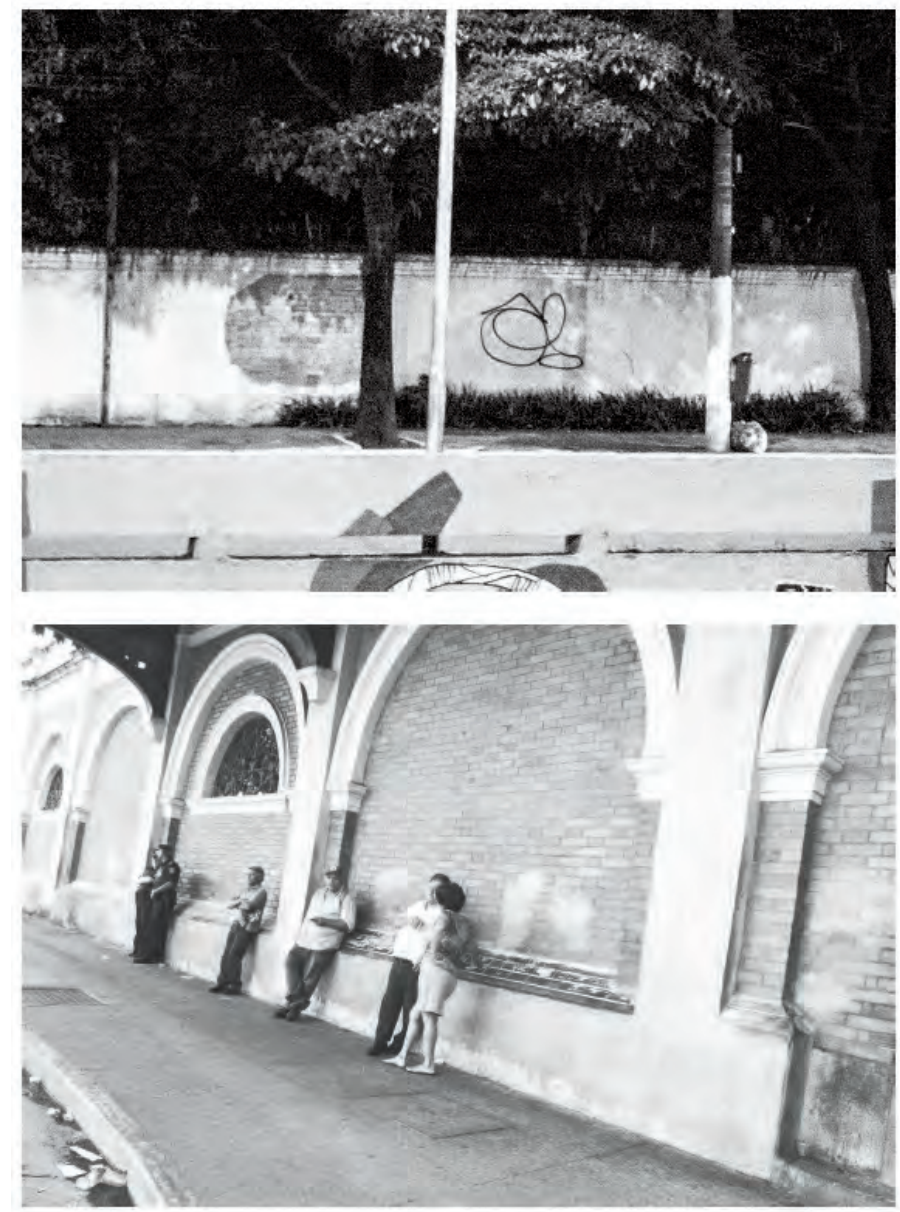
em imagens, por isso pensava num filme com o tempo alongado, onde veríamos a pequena loucura ser dissolvida em atos.

- E você concorda com esse personagem?, diz C.

- Não me faço essa pergunta de começo na escrita, mas de alguma forma sim. Quando a discordância das políticas é tão escancarada, e essa é minha ligação com o personagem, muitas ideias que te levam a ter uma vida mais próxima da que você acredita, sobretudo no caso dele, que não temos todo esse retrospecto que apresentei aqui antes, o filme começando na cena que ele encontra o raio-x, abre um campo de autonomia frente o status quo, que te libera às ideias aparentemente antiéticas. Sobre a coragem, isso também me pega: como esse cara que sempre viveu uma espécie de fraqueza, de falta de estímulo, da inação, vai travar uma batalha criada, fictícia, contra o Estado.

- Sim, diz J.

- Mas é aí, aqui, que a ficção toma a potência de ser o personagem e ser o filme, o personagem e o filme se ligam, fazem esse acordo de proposição-processo. Uma simbiose no inexistente.

- Mas realmente, essa falta de coragem dele não parece ser ultrapassada.

- É, mas vocês não acham que o fato de não ter todo esse histórico que contei na diegese, faz esse personagem ser menos frágil, apenas mais calado, numa vida sombria, e que a imagem lhe faz-traz ação? Talvez seja bom eu continuar a contar como o resto se passa. 
- Em um filme, muito acaba se passando através do ritmo e mise-en-scene, se as cenas se sustentam, se dá vontade de ver a cena seguinte, vamos entrando no universo desse delito.

- É, talvez eu esteja acreditando muito nisso, mas sim, é aí e nas tramas paralelas, que têm quase o mesmo peso de importância, que esse filme pode existir. Vou continuar.

Uma leve garoa, depois de todo o sol, veio num vento gélido na varanda. Entramos com os copos. Não queria continuar no mesmo ritmo, contando tantos detalhes. Alguns nem estavam escritos porque, apesar disso ser criticado, me parece insustentável, ou assim deveria ser, ter um roteiro inteiro quando se começa a produção de um filme. São adaptações que vamos aos poucos fazendo para se adequar às produções onde a lógica do projeto diz quem faz ou não um longa-metragem. Que o projeto seja executado perfeitamente é um ideal-do-idealismo na arte? Como fazer um filme onde quero me adentrar numa aventura processual do personagem sem viver o próprio processo do filme junto com ele, com o ator que irá incorporar o pré-personagem, de toda a equipe e dificuldades-mudanças da filmagem?

- Vocês acham que precisa de muito dinheiro pra fazer esse filme?

- Isso depende de como você quer filmar, mas te ouvindo assim, 


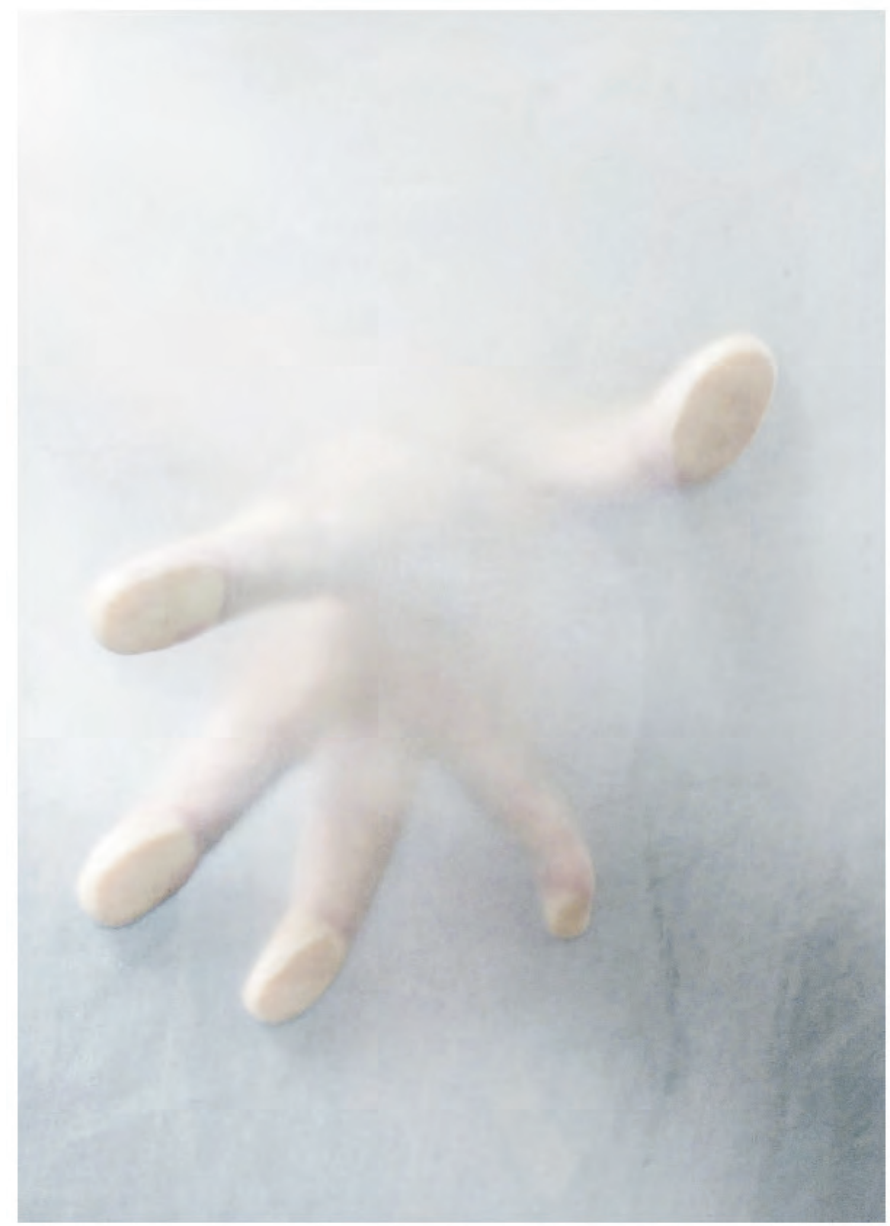


rapidamente, sem ir até o fim, me parece que pelas locações, personagens... quantos personagens tem o filme?

- Aparecem umas dez pessoas no filme mas são três personagens:

o Salvador e as duas Marias, a filha e a dona da casa.

- E os lugares de filmagem?

- Sobretudo a casa. Fora ela o Terminal Barra Funda, alguns comércios do bairro, uma ou outra vez no que seria a administração da empresa, um Poupa-tempo e um consultório médico.

- Eu diria que entre trezentos e seiscentos mil reais. Faz sentido? - Não, mas entendo. Sobretudo porque quero pagar bem as pessoas e ter tempo pra fazer o filme. Como não quero escrever os diálogos, ter apenas diretrizes de assuntos necessários para a narrativa andar, imaginei filmar em três, quatro meses.

- Isso complica tudo. Em geral um longa se faz em cinco, seis semanas.

- Sim, mas realmente isso só traria estresse pra filmagem, não daria espaço para se criar a relação necessária entre os personagens que precisam se conhecer pra se sentirem à vontade de conversar diante da câmera. Gostaria de ter muito mais horas de filmagem do que vou usar. Ter duas, três diárias para tirar um diálogo que deu certo.

- Isso sim é bastante ideal, fora do possível, ainda mais pra você que não tem nenhum longa-metragem.

- Sim, por isso não ando pensando em fazer o filme. Enfim. Vou 
continuar pra terminar: a Maria, filha dele, agora com dezoito anos, no terceiro colegial, pra terminar a escola, visita Salvador três vezes durante o filme. A primeira vez ela passa em sua casa numa manhã e o acorda. Ela faltou na escola. Todos os encontros do filme começam com uma falta de intimidade que vai, ao longo da conversa, se transformando ora em raiva, ora em carinho. Nesse primeiro encontro ele oferece um café e ela o ensina a fazer um pão velho, colocando gotas d'água, ficar como novo. Ela vem cobrar, sem trazer o assunto no primeiro momento, um aumento da pensão. Ele argumenta de como isso fica difícil pra ele, com cem reais a menos eu não consigo nem comer até o fim do mês, e ela sabe disso, mas está cansada de ver o pai, ausente, tendo uma vida que complica a sua. No fim da conversa ele oferece seu bilhete único, que é ilimitado, o bilhete que recebe no trabalho mas não usa pela proximidade entre sua casa e o terminal, pra que ela não tenha dificuldades pra procurar um emprego. Ele, sem grosseria, insiste pra que ela trabalhe ao invés de pensar numa faculdade. Indiretamente isso significa que ele não precisará mais pagar sua pensão. A conversa fica tensa. A despedida desse encontro é difícil, mas não sei ainda o que isso significa. Talvez ela diga que vai ao banheiro e saia sem dar tchau.

Essa parte do roteiro interessa especialmente aos meus amigos. Quase como se eles já tivessem passado por essa situação ou co- 

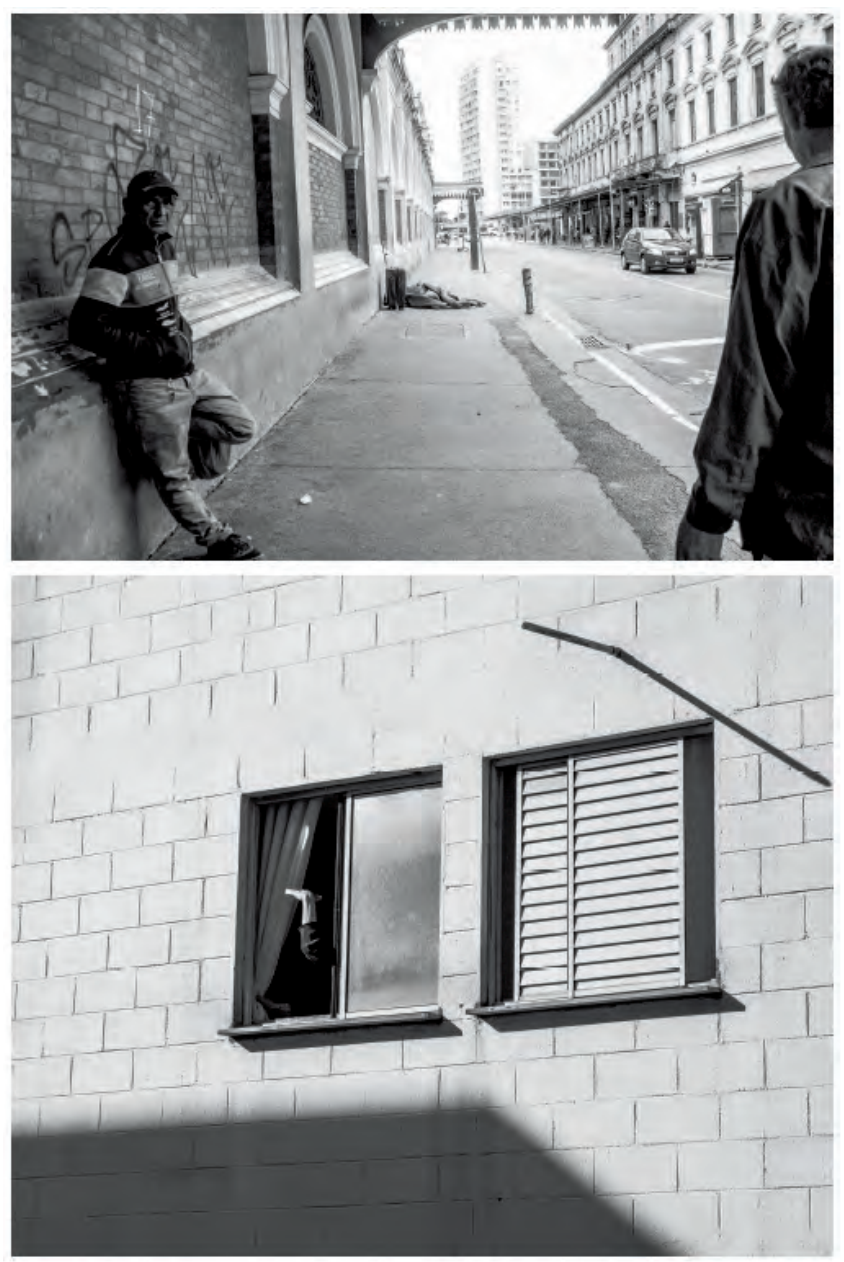
nhecessem alguém próximo que sofre esse litígio doloroso entre família e dinheiro, e conseguissem se colocar mais facilmente no lugar dos personagens.

- A segunda aparição de Maria vem num momento onde Salvador não está em casa. Ele tinha ido à administração da Gato Preto dar entrada no processo de invalidez. Foi seu primeiro teste real com o curativo da mão. Antes só testara nos comércios do bairro e variava o motivo do acidente para os que perguntavam.

- E afinal o que ele colocou como causa do acidente para a empresa? Em geral não precisa ser um acidente de trabalho?

- Não, desde que você está contratado pela empresa, pode ser a qualquer momento do dia, dentro ou fora do horário de trabalho. Ele vê num jornal numa quinta-feira que na noite anterior, na região da Barra Funda, estádio do Palmeiras, houve uma briga grande entre torcidas. Cria então pra si que seu acidente foi no caminho de volta para casa e, passando pelo meio da confusão entre as torcidas, alguém lançou um rojão na sua direção e ele se defendeu pra explosão com essa mão, perdendo assim o polegar, $\mathrm{o}$ indicador e o dedo médio.

- E a partir desse dia ele começa a faltar no trabalho?

- Sim, ele passa mais ou menos uma semana do momento que encontra o raio-x, fabulando sua história, até essa quinta-feira, que seria sua folga. 
- Certo, você tava falando do segundo encontro com a filha, não? - Isso. A Maria chega na casa, toca a campainha e ninguém atende. A outra Maria, dona da casa, ouve a menina no portão e a chama pra entrar. Até ali elas se conhecem mas nunca tiveram muito afeto, foram poucos os encontros, sempre passageiros. Ela explica que Salvador deve ter saído e insiste para a garota entrar em sua casa pra esperar. Maria aceita pela distância entre sua casa e a casa do pai, ela não queria perder viagem. Nesse momento, a outra Maria, dona da casa, já ficou sabendo dos planos de Salvador. As Marias comem um bolo e conversam entrecortado com a televisão ligada. A dona da casa ainda está abalada por ter descoberto as intenções de Salvador quanto à aposentadoria. Dias antes eles têm uma conversa tensa sobre isso, ela o questiona severamente, até pergunta se isso não pode sobrar pra ela agora que ele usou o computador dela pra pesquisar sobre leis trabalhistas, fica assustada em ter esse homem sob o mesmo teto e, no final, ela que também já sofrera o poder do Estado, diz que não quer se meter no assunto e que ele pode tomar conta da própria vida. Eis que, no meio de uma conversa banal sobre Salvador, da vida difícil que tivera, da dúvida de ambas sobre sua relação com a família que ficou na Turquia, Maria não consegue guardar pra si os planos do inquilino e acaba contando à menina. No começo a garota pensa que a outra pode ser louca, mas aos poucos vai acreditando em cada palavra e desata num choro que 

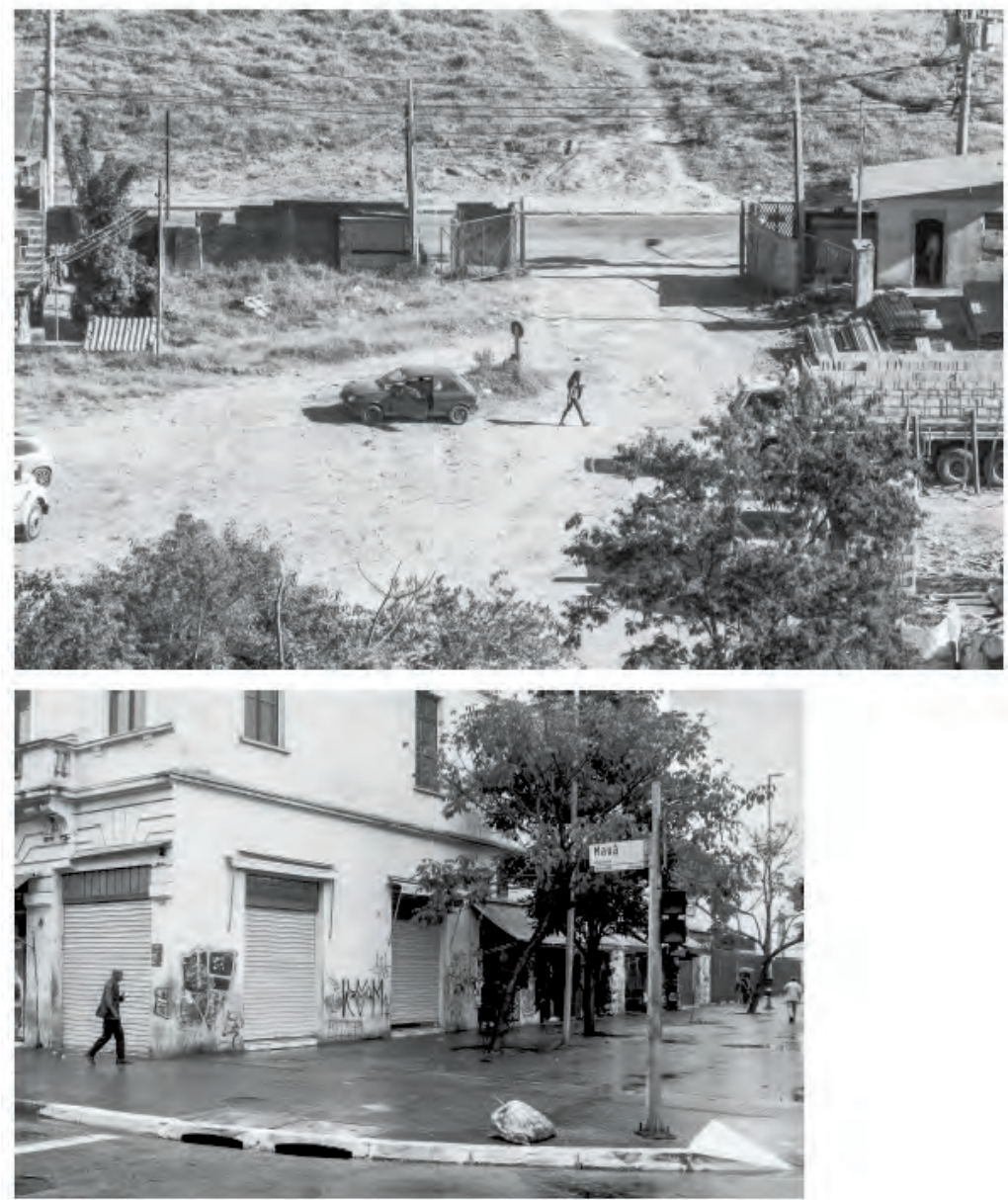
reflete amargura. Rapidamente se contém e se silencia diante da situação. Quando encontra o pai, lida como se nada tivesse acontecido. Inclusive ela nem consegue tocar no assunto da pensão. $\mathrm{O}$ terceiro e último encontro, já com mais da metade do filme passado, tem um tom mais sério e duro. Maria não veio com tempo a perder. Diz ao pai que ele precisa aumentar a pensão, que ela não pode trabalhar nesse momento porque precisa estudar para o vestibular. Quando ele ensaia a retórica de que essa coisa de estudos não vale nada, ela mal o deixa falar, diz que tem controle da sua vida e sugere o intermédio da justiça pra conseguir o aumento da pensão. Ele não entende direito se aquilo foi uma ameaça. A cisão entre pai e filha foi feita.

Chego ao final de tudo o que gostaria de contar, fui preparado pra tratar os mínimos detalhes do roteiro mas aos poucos meu desânimo, vindo com delicadeza da parte dos meus amigos quanto a possibilidade de filmar, foi me esfriando. Nome do edital X, nome do edital $\mathrm{Y}$, tudo aquilo não parecia possível para mim: como convencer o inimigo da sua história a te dar dinheiro?

Sei que vou embora sem falar de todo o processo do personagem. J. me indaga justamente sobre isso enquanto faço o movimento de me levantar da cadeira. Digo que vou ao banheiro e saio sem dar tchau? Não era o caso. 
Eles me dizem que entendem e também prefeririam não escrever os diálogos de um projeto, do engessamento que isso traz, mas que é apenas uma maneira de se fazer compreender as diretrizes de um projeto. E acato essa verdade.

Pressinto que sairei de lá sem contar a cena mais confusa em minha cabeça, o momento epifânico e inverossímil do filme: o momento em que Salvador consegue, numa sala de hospital, sendo examinado por um médico do INSS, o atestado que garante sua aposentadoria. Até agora essa cena começa com Salvador tirando o curativo e mostrando sua mão inteira. O médico, de primeira, ameaça chamar a segurança. Como Salvador irá convencê-lo? Justo este que, em geral, faz justamente o contrário, não concede a invalidez para pessoas que a merecem. Esse roteiro, que é elaborado a partir da potência da inverossimilhança para tornar mais nítida a realidade, não pode se pautar apenas nesta ideia e se facilitar em cenas simplórias. Também o protagonista não é um homem de argumento, não irá elocubrar raciocínios complexos para inverter a moral do médico. Há algum prazer em não escrever e finalizar essa cena, me parece que quando ela estiver pronta, o peso de não transformar o roteiro em imagem vai me tomar, tirando todo o sentido de pensar o cinema. 


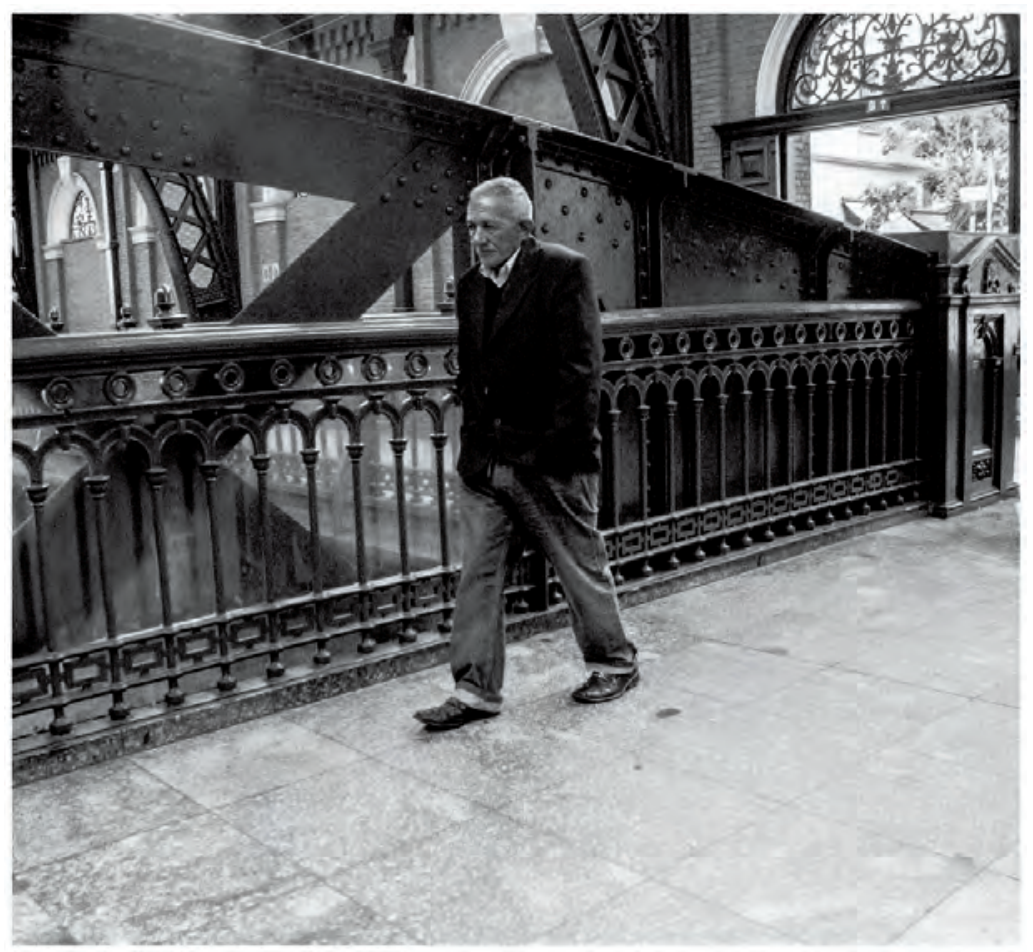




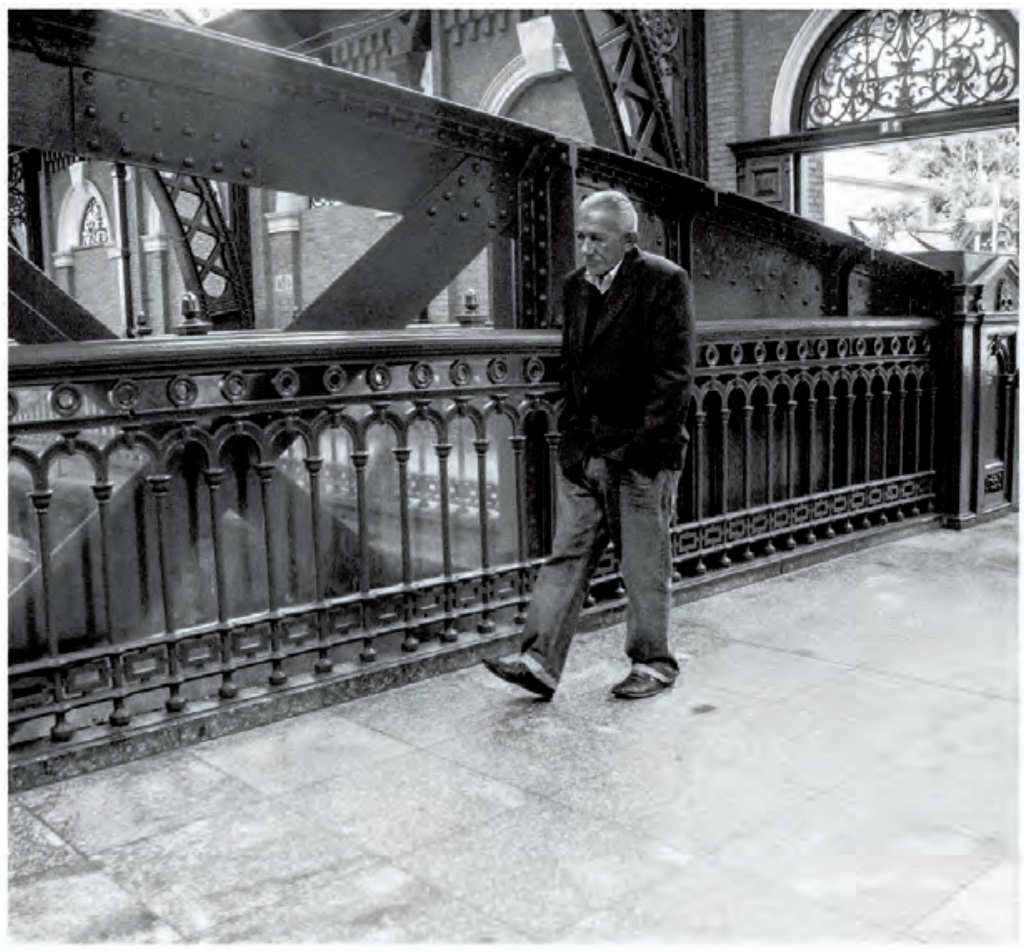


O tempo é raro e, enquanto conto, sei que é mais um roteiro que voltará, necessariamente, à gaveta. Assim serão os roteiros sem concessão, os que não se valerão de grandes atores, da precisão do cinema clássico, os roteiros sem passado que ainda prescindem do dinheiro e da estrutura modelar da História do Cinema. Formulo esses pensamentos relembrando quantos filmes conseguiram transpor essas barreiras.

Um fim um pouco abrupto. Talvez no desânimo de perceber, palavra por palavra, a ineficácia de contar algo que via em imagens, talvez por sentir, ali em protocena, o roteiro na minha cabeça e as palavras vazias nas deles. O paralelo inevitável entre palavras e imagens que dizem eu estou te seguindo, mas são, no próprio ato, o desencontro.

Digo de novo que não penso em filmar por agora, e isso é uma mentira. Digo que sei das dificuldades, mas eram justamente elas que gostaria de derrubar no nosso encontro. Eles me lembram, a todo custo, da dificuldade e da falta de escrúpulos nos procedimentos de seleção estatal do que será ou não rodado.

Ainda que houvesse tempo, pouco me interessava discorrer sobre a relação da Maria, dona da casa, e o Salvador. Ou entre Maria e Maria. Sem desavenças, ouvindo que é um bom roteiro, volto à 
rua, dou um bom trabalho para eles. No portão, J. me pergunta se eu não faria um curta-metragem dessa história e eu digo que sim como se fosse um não. Como filmar em uma dúzia de minutos o notebook quebrado de Salvador, ele descendo as escadas no ritmo lento de um homem à deriva, tocando a campainha de Maria e perguntando se poderia usar seu computador, fazendo uma pesquisa sobre as condições para pedir a aposentadoria por invalidez enquanto ela vê televisão? Como filmar com rapidez a curiosidade de uma senhora vendo seu histórico para descobrir o que, afinal, Salvador tinha visto no computador e descobrindo, entre receitas de bolo, de emagrecimento, remédios caseiros para depressão, seu ímpeto de burlar o Estado da maneira mais precária, numa autêntica revolta contra a vida, escondendo sua força de trabalho sem técnicas ou conhecimentos favoráveis?

Sem tornar este homem num óbvio pai escroto, como mostrar as dúvidas de Maria em denunciá-lo por conta das pensões nunca pagas com decência? E, ao final, semanas depois do resultado positivo, sua aposentadoria caindo na conta, seu tempo expandido, agora em casa, vagando pelo bairro, movimentos lentos, tocam sua campainha. A polícia. Por que ela está ali?

Volto na mesma linha de ônibus pra casa, lembrando de um amigo de infância dizendo que cinema era coisa de gente rica. Tal- 
vez seja uma proposição acertada, talvez também fosse a falta de experiência dele em ver que, se nos dobramos às condições de produção, em qualquer área, sem pesar, as iniciativas-felicidades começam a surgir. Talvez não fosse esse meu ponto com a imagem em movimento.

De volta à Luz, esperando que alguém mais esteja em casa, sinto meu coração pulsar mais forte, prevejo uma dor caso respire mais fundo: chamamos também de simbiose quando dois agentes negativos se acumulam e se nutrem numa relação estável de destruição? Somatizo meu caminho pelo Parque da Luz ouvindo conversas alheias. Cruzo um policial que me olha, talvez por ter ouvido, no ar, que eu não discordo de Salvador. Ou talvez seja simplesmente seu trabalho, encarar os outros a fim de que a verdade surja.

Com descaso, passo o dia com outras ideias na cabeça, até com outros roteiros. A imagem vai se formando e se apagando em mim enquanto digo que ela não ganhará mais vida do que anotações desconjuntadas no computador. O filme simula minha fragilidade, o processo meu desgosto. 


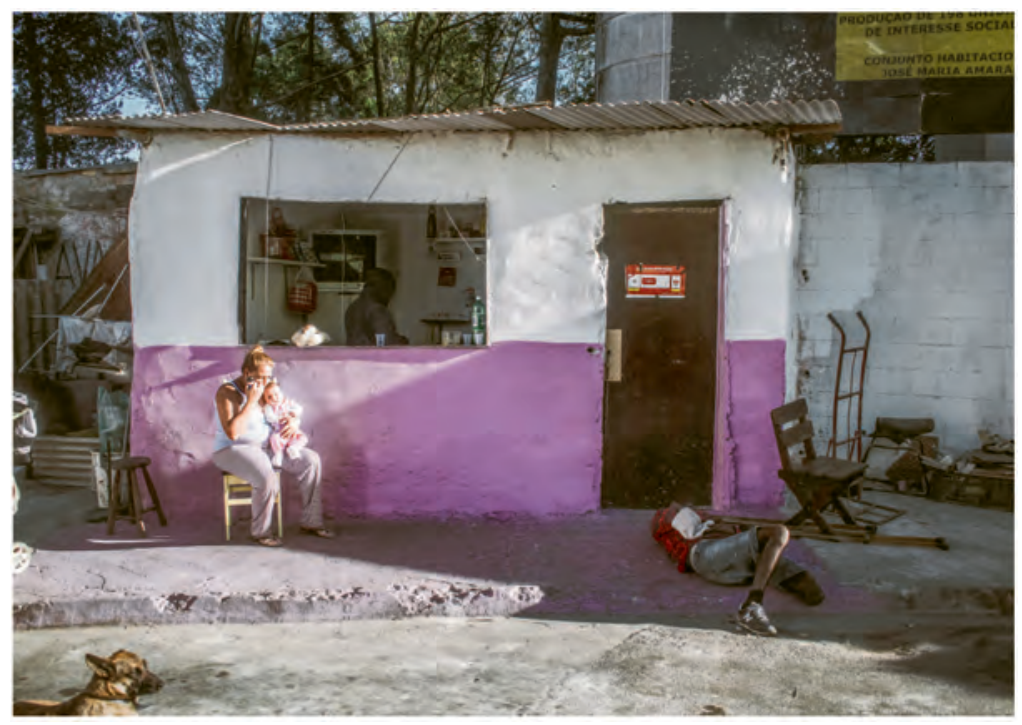




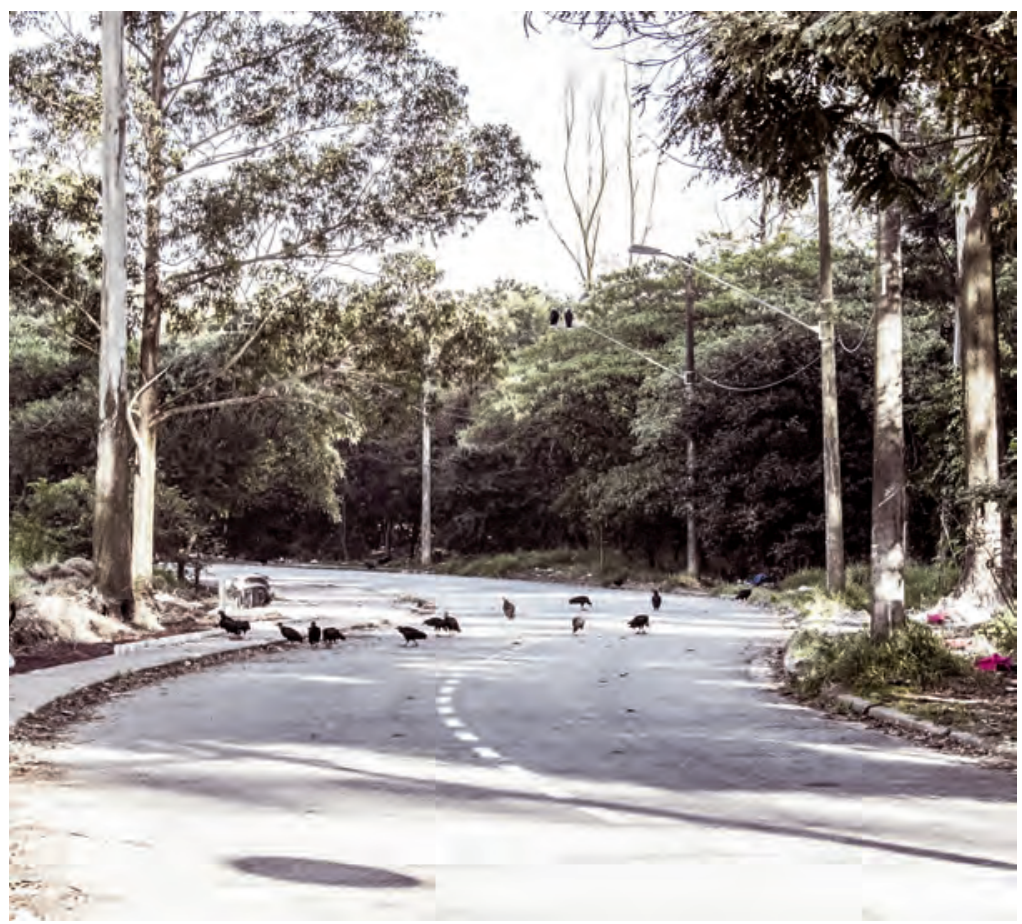


todos os verbos são no passado 
Atrás de cada caverna uma outra que se abre, mais profunda ainda e abaixo de cada superfície, um mundo subterrâneo mais vasto, mais estrangeiro, mais rico e sob todos os fundos, sob todas as fundações, um subsolo mais profundo ainda.

(Friedrich Nietzsche, Além do bem e do mal)

Tenho desde criança uma dúvida, ela me vem ao menos uma vez por ano por toda a minha vida: por que os insetos vão em direção à luz daquele jeito louco? (Ouvido na mesa ao lado, no refeitório) 
(Matéria e imaginação dançam com canções e gritos ao fundo)

Sentados à mesa do bar, quatro amigos, discutíamos, lembrávamos de situações passadas. Um encontro de dez anos, poucas coisas a dizer do agora, muitas coisas do passado vinham. Um começava a contar tal história quando todos ali tinham seus quinze anos e a imaginação criava aquele elo só dela entre seu corpo do presente e o dos outros no passado.

E você pegou a placa e o guarda mostrou a arma na cintura. Você se lembra? Estas recordações vinham como cenas e meu rosto na imagem era o meu de agora e todos eles tinham seus rosto da época. Meu sorriso e os deles ligados por infinitas dimensões. Todos se olhavam e os rostos nunca sairiam do estado de renderização.

Os pequenos detalhes, a cor da placa, o ano, o que se passava na vida de cada um, tudo não era. E quanto mais falávamos, tudo era. As memórias guardavam sensações distintas do mesmo acontecimento. Por vezes soava mentira e quem iria rebater dizendo o que de fato havia se passado? Apenas concordávamos. Uma fotografia da cena nos ajudaria a provar o que teria passado numa ou noutra história? Da nossa adolescência não tenho um registro fotográfico sequer. 
Na manhã seguinte, mostrando algumas fotografias na reunião do grupo de estudo, recebo, pelo elo que há entre o realizador e as imagens, algumas perguntas: Quem é esta pessoa da foto? Onde foi isso? Aqui é a Praça da República? Por um momento me inibo ao silêncio e penso em desvendar todos aqueles enigmas que trocariam a lógica da imagem fotográfica, muda ${ }^{1}$, por palavras que preencheriam ou conformariam o imaginário.

Muitas ideias do que a fotografia representa vieram acompanhadas de palavras fora do próprio meio de sua apresentação. Mostrar imagens aos outros é em si uma outra coisa que a fotografia. É a fotografia em consonância ao seu realizador, à palavra. As fotografias soltas no espaço-tempo, sem estas palavras, tomam outras dimensões e era isso que me levava à produção de imagens. Não queria perder esse poder, essa inquietação².

...seria uma imagem que, antes de mal representar algum fenômeno, pode-poderia ser vista como uma presentação em si. A fotografia presenta ela mesma, ao invés de só representar, como tem sido pregada sua episteme. Mesmo os que desejam que a fotografia tenha um valor documental, marca potente de seu meio, não devem deixar de lado sua existência em si, seu silêncio em

${ }^{1}$ Muda, silenciosa. Muda, mutante, movimento.

${ }^{2}$ A fotografia com seu realizador falador está mais próxima do cinema do que da fotografia em si. Deixo aqui como nota o filme (nostalgia) de Hollis Frampton, 1971. 
si, seu deslocamento que nasce da separação de um ocorrido, na transformação de uma visualidade tridimensional em superfície plana, tudo conectado pelo ato, instante vivido de uma perspectiva única em tempo e espaço apenas passível de semelhança a ser lembrada.

A própria presença da câmera muitas vezes transforma as ações. Quero dizer que, além da própria materialidade específica da fotografia, que não deve ser confundida com o que ela representa, o espaço vivido também é alterado, tanto pela presença do aparelho, quanto pela ideia de uma fotografia ser feita naquele espaço, modificando os atos dos presentes. Também venho pensando, sem chegar a conclusões, olhando fotografias antigas, vendo os rostos das pessoas nas fotos, se seria possível dizer que os meios técnicos, a fotografia e o cinema e mais tarde o vídeo e o digital, podem ter alterado as expressões faciais e os movimentos das pessoas.

Assisto uma aula da professora Michelle Debat, ela coloca uma questão aos alunos: Qual seria a diferença para um dançarino em ser filmado e fotografado? A pergunta vinha propor uma reflexão em como até mesmo o modo de dançar de uma pessoa quando se sabe fotografada ou filmada, pode ser alterado: para a fotografia, uma pequena pausa formando uma pose, para o vídeo, o pleno movimento. 
Quando aponto para a necessidade de perceber a própria fotografia, antes de tudo, como uma fotografia, regredir um instante no olhar e procurar a materialidade do objeto fotográfico, seja ele visto na tela de um celular, seja no jornal, museu ou livro de fotografias, quero pensar no peso do ato fotográfico, na presença de uma câmera no espaço, nas relações que se colocaram naquele momento, nos desejos do fotógrafo e nos desejos que fazem tais imagens estarem em tais lugares (circulação). Denis Roche, escritor e fotógrafo, em um conjunto de crônicas sobre algumas fotografias específicas ${ }^{3}$, se propõe a compreender o corpo do fotógrafo em dada fotografia. Como foi o momento em que aquela imagem foi realizada. A respeito de uma fotografia de Lee Friedlander em Albuquerque, Estados Unidos, Roche olha para as sombras projetadas e se pergunta sobre a que hora a imagem foi feita, observa todas as linhas produzidas pelo enquadramento, a presença do cachorro parado tranquilamente. Ele se pergunta: Quantas fotografias Friedlander fez antes e depois desta, neste mesmo local?

O olhar que incarna a matéria da imagem fotográfica, incorpora a luz, as cores, o corpo do fotógrafo, a maneira como a fotografia circula no mundo consegue escapar ao discurso que tenta fazer você olhar algo na imagem transformando-a em uma obra

${ }^{3}$ Écrits momentanés: chroniques photo du magazine city 1984-1987. Paris: Paris Audiovisuel, 1988. 
audiovisual ${ }^{4}$. Ver imagens como imagens me parece fundamental no contemporâneo, visto que boa parte de nossas vidas já ocorre no virtual, no online, e a tendência é disso só crescer. A confusão entre ser e imagem do ser, é onde se apoia, por exemplo, a farsa da publicidade.

O que se vê em uma fotografia não necessariamente aconteceu fora da própria fotografia: uma das características deste suporte, que se apresenta em superfície, é misturar perspectivas, alterar de acordo com a configuração do aparelho, a luz do momento, aumentar ou diminuir profundidade de campo, foco e desfoque, trabalhar em cor ou preto e branco, produzir uma imagem com ou sem rastros, borrada, e, como já dito, a partir de um ponto de vista capaz de criar imagens com atmosferas que não estão acontecendo fora da imagem. L. me mostra algumas de suas fotos: primeiro vejo uma fotografia de um homem de cinquenta anos com a mão aberta na frente do rosto, impedindo o retrato. Uma fotografia forte, a primeira impressão que tenho da imagem é que L. foi imprudente e fez a fotografia sem consentimento. $\mathrm{Na}$ sequência ele me mostra a fotografia feita no instante seguinte, o mesmo homem sorrindo para a foto, agora de óculos escuros. Se tomasse apenas a primeira fotografia, pensaria no descuido das relações entre fotógrafo e fotografado de L., vendo a segunda

${ }^{4} \mathrm{O}$ que pode ser interessante. 
entendo que já havia um acordo entre os dois e que as fotografias apresentadas lado a lado estão colocando em questão a relação entre os participantes do ato fotográfico.

Este e outros acontecimentos me fazem pensar na afirmação forte do texto de Barthes, já muito discutida, sobre a fotografia sempre ser fruto do que estava na frente da lente, ele diz: Isso foi $i^{5}$. De fato, sem alterações na pós produção, o que foi impresso no negativo, se pensarmos que Barthes escrevia no momento em que o negativo era o principal material fotográfico, será uma combinação do que esteve na frente da câmera, do ajuste da câmera, da lente que se tinha, e da cromática e sensibilidade do negativo escolhido. Poderíamos falar também da cópia feita a partir do negativo, visto que na fotografia analógica, rara era a circulação direta do negativo e sim das cópias feitas em laboratório a partir do papel sensível. Faço dois parênteses: a própria cópia em si, muito antes do photoshop, era digna de manipulações fantásticas, onde o laboratorista poderia ressaltar ou apagar detalhes das imagens, alterando a percepção de contraste e equilíbrio visual da imagem, de maneira a salvar ou destruir uma imagem. Também destaco aqui o texto da pesquisadora Anne-Cécile Guilbard, Fotoliteratura analógica dos anos 80: o canto do cisne? ${ }^{6}$, onde ela

${ }^{5}$ ça a été

${ }^{6} \mathrm{http} / /$ phlit.org/press/?p=1457 


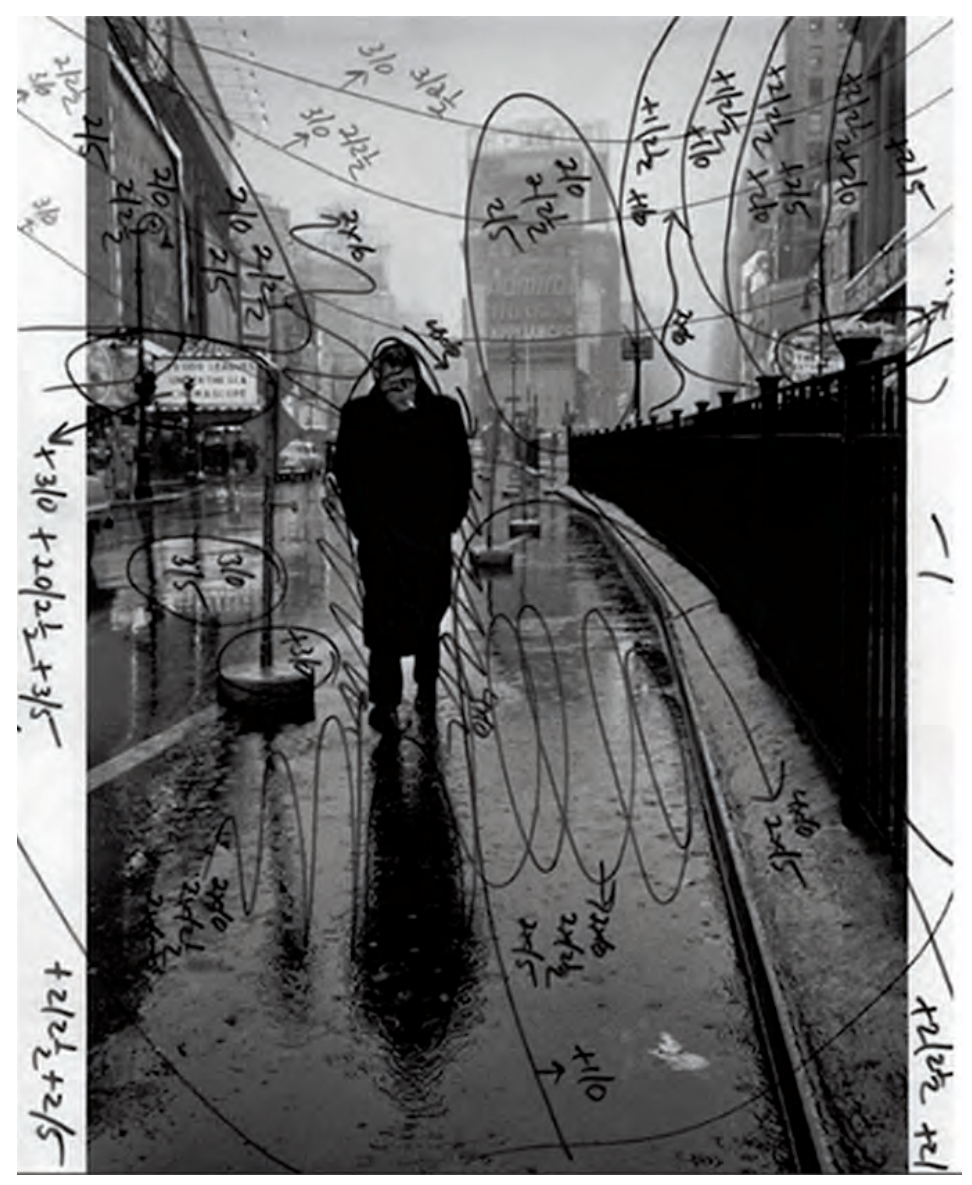




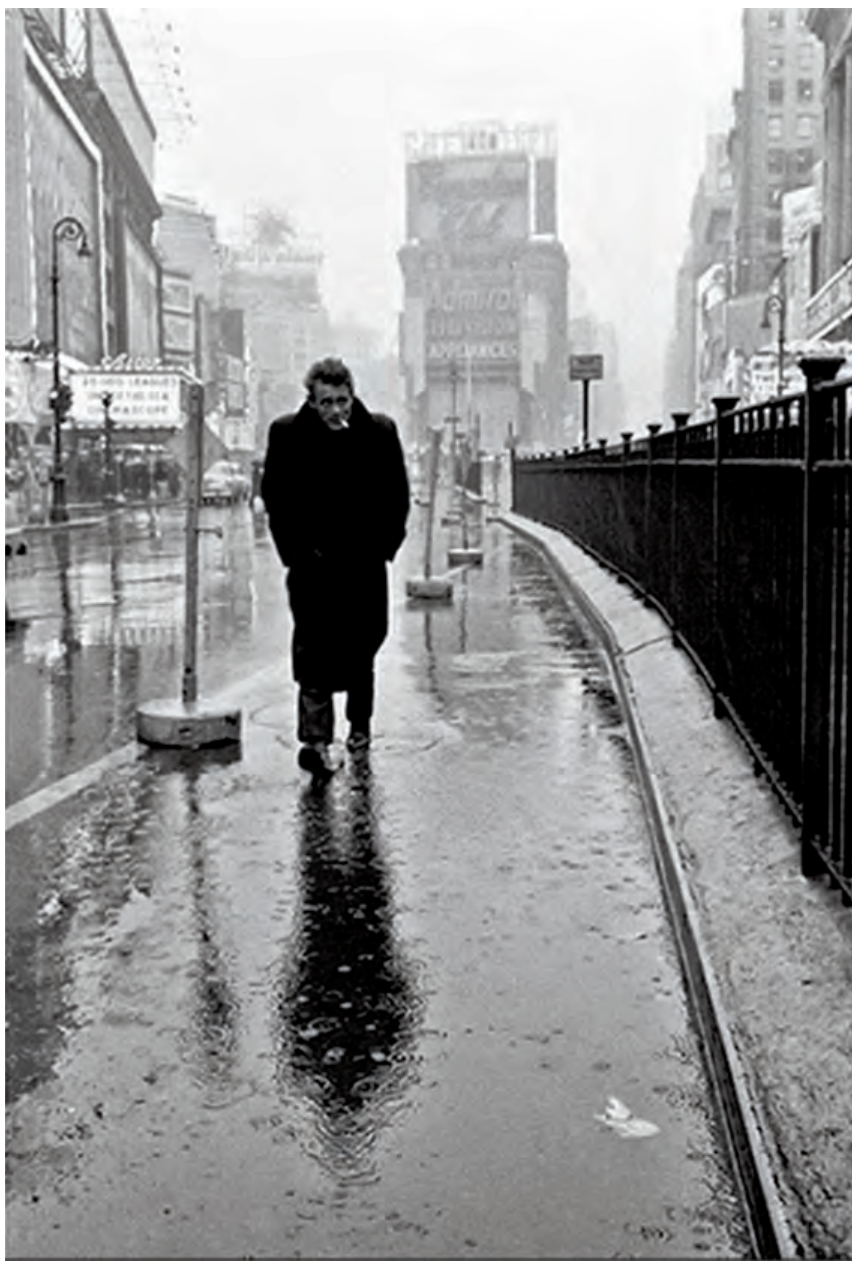


comenta a importância da prática fotográfica nos textos de alguns escritores dos anos oitenta, que acabam trazendo para a narrativa partes sensíveis da realização de uma foto, mas que costumam ficar invisíveis até mesmo na crítica especializada. Voltando à frase do Barthes, vejo que meu interesse não é negar sua proposição, o isso foi, mas que a fotografia transforme a afirmação em pergunta, isso foi?, que frente à imagem não hajam afirmações de antemão que esgotem e condicionem o olhar.

Antes da representação, ato de difícil restituição, o que poderia representar algo sem desvios, sem alterações necessárias de serem notadas?, a fotografia é antes de tudo um enquadramento imóvel em 2D. Apresentar uma fotografia será sempre o desejo de pôr uma imagem em algum contexto. O contrário não pode ser esquecido: a imagem deslocada, apresentada em outro lugar do que o desejado por seu autor, é o descontrole da vida das imagens. Walter Benjamin em O autor como produtor, de 1934, faz uma defesa com relação a como ver fotografias: diz que as imagens precisariam de uma legenda explicativa para saírem da moda e caminharem para a revolução. Na sequência ele cita uma frase de Brecht, dizendo que uma fotografia das fábricas do grupo Krupp ou da AEG não diz quase nada dessas instituições, apontando que na mera imagem da fachada ou das máquinas dos galpões não veríamos o processo de reificação e exploração do 
ser humano. Aqui aponto para o verbo escolhido, diz, para concordar com Brecht. As fotografias não falam, não à toa seus usos beiram o infinito. Essa é sua máxima qualidade e o desapontamento dos que gostariam do contrário. $\mathrm{O}$ discurso pode se valer da fotografia, mas será um corpo estranho à imagem.

Mas há um desdobramento quanto ao uso da palavra, legenda e discurso anexados às imagens. A presença das fotografias no mundo, agora já se aproximando dos seus duzentos anos, tem nas próprias formas, nas características estéticas, o seu discurso. Com isso, quero dizer que o texto de alguma forma se transformou em luz, em encenação, em distância focal, close, em pixel. É difícil ou impossível não olhar uma imagem através das nossas referências, da nossa própria vivência no mundo das imagens. Quando vemos uma foto, levando em conta seus espaços de circulação, temos uma taxonomia colocada para experienciar as imagens como: esta foto é uma publicidade, é um ensaio de moda, é uma foto de arte, fotojornalismo, é de verdade, encenada, antiga, feita para ser bonita, para desagradar...

...e que uma curva nesta proposição aqui apresentada de ver as imagens que subvertam a lógica de verdade, de acontecimento, de representação de ausências, seria também o deslizamento de imagens que bagunçam os gêneros já pretendidos de uma espé- 
cie de sintaxe da imagem: o reembaralhamento dos signos de leitura, ou melhor: que desqualificam a idéia de que uma imagem pode ser lida, que ela tenha uma sintaxe, e as levem em direção à dificuldade do discurso frente à visão.]

Você abre o aplicativo de filmes, que vai acabar antes do que se imagina, você vê um filme. Você gosta do filme. Passam dias e você volta ao aplicativo e ele te sugere, porque você viu o filme anterior e o avaliou com muitas estrelas, um outro filme que o algoritmo considera parecido. Você não gosta do filme.

A taxonomização de obras artísticas procura transformar em número-palavras, tags, sensações que naturalmente não estão sob controle. Há uma maneira delas estarem sob controle: quando a obra em si é pautada por discursos que fariam da imagem maneiras de se transmitir idéias de um texto já préestabelecido, quando uma forma representa um conceito.

Em ferramentas e aplicativos de compartilhamento de imagens é possível anexar à uma fotografia uma hashtag na qual está descrito o que foi desejado conectar textualmente à imagem. Isso determina uma conexão entre palavra e imagem já produzida pelo realizador do post. Isso implica em uma segmentação gerida pela palavra, onde a pessoa que busca, cerca o escopo de imagens desejadas. 
As hashtags hoje são uma das maneiras de se espalhar imagens na internet, aumentando a possibilidade de acesso, de visualização de imagem e ou conteúdo, furando as bolhas propostas pelas redes sociais, onde apenas as pessoas próximas à você conseguem ver o que você está compartilhando. Uma outra maneira de furar esta bolha é fazendo comerciais online, ferramenta paga e que segue a lógica dos anúncios de TV e Outdoors. Mas haveria uma maneira de se tentar furar essa bolha sem precisar determinar a segmentação da imagem, ou seja, sem o produtor daquela imagem precisar dizer o que aquela imagem é e indeterminar seu público. Utilizar, por exemplo, hashtags aleatórias, de modo que se a pessoa busca por uma coisa, ela verá outras diferentes daquelas desejadas, tirando o conforto da união entre palavra e imagem ${ }^{7}$.

No final de maio passado, com amigos em casa no domingo, depois de uma longa festa, tenho uma crise de pânico. Lembro do receio de sair de casa e o de ficar. Os dezesseis andares até o apartamento me assustam. Desconfio da solidez do prédio. Passo alguns dias sem deixar o apartamento, pouco me mexo, saio acompanhado, tomo banho somente com pessoas na casa.

${ }^{7}$ Este é um site que cria hashtags aleatórias: https://www.all-hashtag. $\mathrm{com} /$. Este uso da aleatoriedade é frutífero quando falamos de imagens, na medida em que se procura a indeterminação do discurso em suportes não discursivos, que podem ter uma sobrevida ao texto. Essas idéias não querem apontar para o caos e destruir as incríveis contribuições que a internet e as redes sociais podem trazer à pesquisa. São ideias para tirar amarras do que já aparece estabelecido. 
Tenho um jantar numa noite de domingo, passo a tarde sentado à mesa da sala, grande, transformada em ambiente de estudos. As amigas, cada uma num vértice, copos de café, começo a perder o controle do corpo, tremo. Ao mesmo tempo de tudo, encontro na internet um texto de Deleuze, Platão e o Simulacro, do livro Lógica dos Sentidos. O ensaio parte da reversão da lógica dos simulacros em Platão. O conceito do simulacro, oposto à produção mimética, deveria ser posto de lado, pois traria algo contrário ou turvo da essência da coisa imitada. O simulacro não deveria fazer parte da República sonhada por Platão. A produção artística deveria trazer a verdade da natureza. Deleuze, a partir de Nietzsche, propõe partir do contrário e ver as potências do simulacro, a potência do falso ${ }^{8}$.

O texto me atinge, demoro a chegar ao final me detendo em sentenças amigas às que vinha procurando existir em imagens. Deleuze não faz uma citação sequer à fotografia, no entanto, parte do que diz, considero, encontra nela profunda ligação.

Nietzsche desdenha o modelo: o pensamento conforme deve ser posto de lado. Em seu livro Além do bem e do mal, o filósofo

${ }^{8} \mathrm{Na} 31^{\mathrm{a}}$ edição da Revista Ars, foi publicado o texto de Eric Baudelaire, artista contemporâneo franco-americano intitulado Potências do falso. Baudelaire propõe uma reflexão do tema na contemporaneidade. O texto foi traduzido por mim e Nina Guedes. 
pretende ir contra as dicotomias ditas vagas, que se valem da afirmação do enunciador do que é ou não é. O modelo deve ser evitado, desmoronado no solo, dando à criatividade, ao erro, o espaço das novas existências. Seria assim a potência do falso uma oposição ao que se diz verdadeiro: mas não para consolidar uma sociedade pautada no falso, mas abrir o espaço da dúvida, do paralelo, do perpendicular, das tangentes. Menos o grito pela originalidade, mais do experimento, esquecer a régua e desistir do padrão.

Deleuze não reflete propriamente sobre a fotografia em seu ensaio, mas traz o pensamento desenvolvido a partir de Nietzsche em seu livro Imagem-Tempo, sobre o cinema. Lá apresenta essa força criativa de dissolver as barreiras entre o verdadeiro e o falso. Entre o que é e não é, próprio à ficção. A ficção erige a dúvida, especialmente no cinema, porque vemos durante a exibição do filme algo que está entre o que é e o que não é. Feito a partir de corpos reais, de cenários reais e construídos ${ }^{9}$, o filme prescinde de um objeto para ser impressionado e quando montado ganhar a dimensão narrativa, seu sentido.

${ }^{9}$ Que não perdem em realidade: a ficção é sempre um desejo de ficção onde vemos em sua materialidade, a construção do cenário, as interpretações, o documento de uma pessoa abdicando de sua persona para contar a história de um outro, viver os sentimentos de um outro. 
A ficção propriamente dita não participa da fotografia aqui discutida: a não ser para as fotos montadas, quando se dirige os corpos envolvidos, a fotografia é muito mais uma espera ou um posicionamento do que ficção. Mesmo esta perspectiva que tento apresentar é difícil chamar de ficção. Entre o documento e a ficção existem muitas coisas, uma dentro da outra, e da foto que não se consegue recuperar a função documental, que não se recupera seu tempo e espaço, suas intenções, que não se compreende o que estava acontecendo, vejo um viés criado do real. Uma geração de real no clique. Pela simplicidade do seu ato, um instante fixado sem antes nem depois, não precisa da fiç̧ão para criar inexistências. Ela pode fotografar o que nunca aconteceu porque uma imagem separada do mundo ganha a força de se relacionar com o modelo da representação, sem, no entanto, necessariamente afirmá-lo. Ela pode existir pela dúvida. São as fotografias da dúvida, da dificuldade de restituir o pretenso real que me interessam. Um real que o olhar tenta adequar, mas a falta de legendas, de discurso quando apresentadas, a alternância de contexto, atrapalha seu amansamento ${ }^{10}$. Aquelas que, mais do que nunca, se relacionam com nosso imaginário. Aquelas que fazem lembrar que nosso imaginário, nosso corpo, nossas capaci-

${ }^{10}$ Como as fotos que vemos apenas uma vez na vida: quando vamos contar a alguém delas, descrevê-las, aquele segundo anterior, antes de começarmos a falar. Essa imagem. 
dades imanentes de ser, são fundamentais para se relacionar com o mundo, com imagens (hoje mundo): somos afetados por estas imagens sem nunca encontrar um equilíbrio, um é, mas um está.

O falso, palavra difícil, existe aqui no texto para desmoronar o verdadeiro. Nem verdadeiro nem falso, as dicotomias servem para erigir o preconceito, o modelo, o certo, o errado. Prefiro ver o errado, o mal, o falso e o bom como parentes de oposição. Eles se unem não para propor uma existência do inverso, mas para lutar contra a corrente modelar. Não seria, na produção de arte, o desejo de produzir um falso em si, por si, mas margear a possibilidade de que aquilo desvirtua os métodos e procedimentos vistos como certos, ou que, no caso da fotografia, ponha em prática a desconfiança, a imprecisão, a impossibilidade de determinar o objeto vislumbrado como procedimento e não como fim. Estas ideias são apresentadas aqui quanto ao ato fotográfico e a imagem criada, mas podem ser desdobradas para os materiais de produção, desrespeitando a hierarquia das boas lentes e papéis corretos de impressão, agora já ao lado do celular, do xérox e da folha sulfite. É a queda do valor real das coisas, do artista, num agora de circulação que pensa e sente os materiais de produção e a ética implicada no processo de feitura, antes de cultivar e cultuar determinados modelos do bem fazer. 
A dúvida é o movimento de abertura, a potência do falso não quer apenas se opor ao verdadeiro, mas trilhar caminhos não percorridos.

a mata fechada

abre ou passa entre

a subida do morro

a estrada de sempre passa por baixo

as pessoas miniaturas

pelo morro não há caminho

um lago uma miragem à direita desconhecido

O falso que se deseja falso como espetáculo da burla, como inverso do verdadeiro, que não pretende desfazer a dicotomia, prefiro pensar como farsa. A farsa, para distinguí-la do falso, seria a falta de força, de potência de se lutar contra os modelos e, se valendo deles, se apresenta como uma alternativa que se vale inteiramente do verdadeiro, não pretende nada destruir, está ali 
apenas como uma oposição frágil do vigente, mas sem perder a amizade. Ela antes se apresenta como possibilidade de se tornar o modelo, mantém os desejos na diagonal progressiva do desencontro $^{11}$.

${ }^{11}$ Hollywood. 
Diversos artistas e fotógrafos ${ }^{12}$ sofreram e se valeram do problema da semelhança na fotografia tornado potência na dissemelhança. Joan Fontcuberta, o artista e teórico espanhol, tem dois livros publicados no Brasil, A caixa de Pandora e $O$ beijo de Judas, em que reflete a partir de seus trabalhos e de outros realizadores, as aventuras das fotografias no mundo. Tem um estilo provocador, cria frases de efeito, mas sente-se um grande empenho e amor pela fotografia em todas as linhas escritas. Num entreparágrafo, Fontcuberta insere a frase: Toma cuidado: por brincar de fantasma, te transforma nele. Era uma citação de Roger Caillois, a mim um desconhecido.

Envio essa frase a uma amiga que vinha pesquisando assuntos próximos: a imagem, a imaginação como fantasmas, assombrações do cotidiano ${ }^{13}$. A analogia entre o fantasma e a imagem é orgânica à fotografia. Ela produz e nos transforma em fantasmas.

${ }^{12}$ Não separo os dois, deixo aqui uma referência interessante para o assunto, apesar de não concordar com essa característica de demarcação entre territórios: o livro A fotografia, Entre o documento e a arte contemporânea de 2005, do teórico André Rouillé.

${ }^{13}$ Dissertação de mestrado da Renata Passos, https://bax-uva.github.io/ fantasmas/ 
No mesmo momento estava traduzindo com a Nina o livro do Hervé Guibert ${ }^{14}$, A imagem fantasma, onde o jovem autor francês, na época com vinte e seis anos, entre a ficção e os acontecimentos do cotidiano, escreve como fotografias invadiam a sua vida, seja como fotógrafo, seja pela presença massiva das imagens nos anos 80: a escrita autoficcional seria um desdobramento, uma sublimação?, para a experiência no mundo transpassado por imagens.

Então descubro que Caillois era um intelectual da metade do século vinte, havia escrito diversos livros e foi responsável por traduções e publicações de autores argentinos na França, como Borges ou Cortázar. Escreveu sobre literatura, religião, antropologia, geologia, etc... escreveu sobre a mimesis no mundo animal. A citação de Fontcuberta vinha d'O mito e o Homem, livro publicado, mas esgotado no Brasil. Era a epígrafe do ensaio Mimetismo e psicastenia legendária. Prends garde: à jouer au fantôme, on le devient. A edição que tenho do livro deixa dúvidas se a frase é dele. Não há referência direta. Composto por outros seis ensaios, as outras epígrafes acompanham seu autor, Balzac, Nerval, Cheu Hoang-Ti, Baudelaire, etc... Esta é a única sem referência, o que me traz a pergunta se foi escrita pelo próprio autor ou se era um pensamento que pairava por aí.

${ }^{14}$ L’image fantôme, Hervé Guibert, de 1980. 
Neste ensaio, Caillois investiga a mimesis na biologia, especialmente nos insetos. O ensaio anterior é inteiramente dedicado à influência do louva-deus na constituição de mitologias pelos continentes afora. Visto como presságio de um bom futuro, como azar, como outra classe de seres humanos, o louva-deus está presente em diversas culturas, aponta Caillois, especialmente por suas características próximas ao homem: é o inseto que tem pescoço, sua cabeça se vira para os lados para observar e passa boa parte do tempo em pé: suas quatro patas traseiras são suficientes para sua sustentação, o que transforma as duas dianteiras em braços que se esticam e dançam no ar.

Caillois tem um olhar holístico da vida. Cria o caminho fabulatório da construção dos mitos através da observação dos animais pelos humanos como constituição dos comportamentos mimetizados. Uma passagem:

Os romenos conhecem diferentes lendas que marcam o caráter diabólico do inseto que eles chamam, no entanto, de calugarita, que significa freira. Conta-se que durante as perseguições aos cristãos - Pedro e os antigos da Igreja - decidiram convocar as mulheres como missionárias. Mas para se proteger contra os olhares dos pagãos, elas deviam se cobrir com um véu e não falar com ninguém no caminho. Uma dessas mulheres, chamada 
Calugarita, foi abordada por um homem muito bonito, ninguém menos que o Satan. Ela tirou o véu e falou dos ensinamentos de Cristo. Imediatamente o homem se tornou invisivel e sumiu. Pedro, advertido por um anjo, chega raivoso e vê a mulher sem o véu. Para puni-la, a transforma em inseto. Ela se torna assim a Calugarita. Mas vendo-o chegar, ela quis recolocar rapidamente o véu sobre seu rosto: assim, transformada em louva-deus, ela colocou e coloca ainda, suas patas a frente da sua cabeça para se esconder ${ }^{15}$.

Pego outro momento do texto, talvez por interesses diversos aos aqui pensados. Caillois escreve agora, no mesmo ensaio, sobre a cópula dos louva-deus.

Em 1784, J.L.M Poiret, no Cadernos de Física, comunica a observação feita de um louva-deus decapitando seu macho antes de copular com ele, e o devorando inteiramente após a cópula. Esta narrativa foi corroborada com fortes detalhes agravantes por um recente e dramático relato de Raphël Dubois. Pensávamos primeiro com Paul Portier que este canibalismo se explicava pelo fato da louva-deus, precisando de matérias albuminosas e protéicas para a fabricação de seus ovos, não poderia as encontrar em outro lugar, com tão grande quantidade, quanto em

${ }^{15} \mathrm{O}$ mito e o homem, página 42, tradução minha 
sua própria espécie. Esta hipótese sofreu oposição por objeções de E. Rabaud que observa sobretudo que a louva-deus não come o macho no momento em que precisa dessa alimentação ${ }^{16}$.

O que Caillois está aventando, a partir dos estudos destes biólogos citados, é que o ato de arrancar a cabeça do macho cortaria a conexão entre o corpo e sistema nervoso, levando o macho a execução de movimentos espasmódicos de maior duração. A ablação feita pela fêmea como ato condicionado já por um princípio do prazer, e que leva o amante à morte.

Não foi o louva-deus que me levou à Caillois, mas o animal me fez vaguear. Voltando ao seu outro ensaio: Mimetismo $e$ psicastenia legendária. Na biologia comparada o mimetismo vinha ganhando características de utilidade. Ainda se fala em mimetismo defensivo ou de ataque: como animais ganham formas adaptativas visuais e imitam e imergem no meio. De partida Caillois diz querer pensar de outra forma a ação e os porquês do mimetismo na natureza.

Ele elenca por quase todo o texto diversos bichos, geralmente insetos e répteis que encontraram formas miméticas de rara beleza. Seria incrível ter uma edição deste texto seguido das imagens

${ }^{16}$ ibdem p.54 
dos bichos citados. São borboletas que imitam corujas, a lagarta que transforma sua cauda na cabeça de uma cobra ou a lesma marinha que se funde com o fundo do mar. Fala das rãs e camaleões que trocam de cor para se envolver e se perder na mata. A visão é uma das fontes de produção do mimetismo, isso é notado a partir das espécies que ao longo da evolução se tornam cegas ou sem olhos, e que perdem suas características miméticas.

O ensaio faz curvas, Caillois citando estes inúmeros casos de mimetismos, aponta para alguns exemplos em que o mimetismo no reino animal não necessariamente traz vantagens para a espécie, e vez por outra chega mesmo a atrapalhar.

Um caso especial são as borboletas Coenophlebia Archidona da América Central, que mimetizam em suas asas folhas secas, inclusive com machucados, como furos ou partes comidas por lagartas. O caso chega ao extremo com algumas espécies do bicho-pau, que imitam tanto a folhagem que chegam a se morder entre si, de maneira que poderia-se pensar em uma espécie de masoquismo coletivo, levando à homofagia mútua ${ }^{17}$.

Fazendo uma oposição entre o mimetismo cromático, aquele da imitação da cor, e o mimetismo morfológico, o que imita

${ }^{17}$ Le mythe et l'homme, Mimétisme et psychasténie légendaire, p.106. 
as formas do habitat, Caillois diz que este segundo seria uma verdadeira fotografia, mas da forma e do relevo, uma fotografia sobre o plano do objeto e não da imagem, reprodução no espaço tridimensional com plano e profundidade: fotografia-escultura ou melhor, teleplastia se tirarmos da palavra todo seu conteúdo metapsíquico ${ }^{18}$. Repensando o transformismo, Caillois recorre à explicações dadas através dos tempos e desejos: Tylor, Hubert, Mauss e Frazer já haviam falado das coisas que em algum momento já tiveram contato restam unidas e associadas ${ }^{19}$. Esses fenômenos de mimetismo são regidos pela lógica de que o similar produz o similar. Vignon fala que o luxuoso mimetismo dos insetos estudados é pura estética, arte pela arte, decoração, pesquisa, elegância. Nega toda a finalidade, o vivo, no espaço tal qual a física o concebe ${ }^{20}$.

Queria somar aos animais apresentados por Caillois o sapinho preto do Monte Roraima, que conheci no documentário Life dirigido por Martha Holmes e narrado por David Attenborough, produzido pela BBC. Seu nome é Oreophrynella nigra. Vive em altitudes de mais de mil e quinhentos metros, nas rochas empilhadas, separadas, já não sei se dizemos nuvem ou ainda neblina nesta altura. Este sapo tem uma aranha, muito maior que ele, como predador. No topo das pedras, tão escuras como ele - ele ${ }^{18}$ Idem. p102

${ }^{19}$ Idem. p106

${ }^{20}$ Idem. 117 
é minúsculo -, aparece a enorme aranha. Assim que percebida, instantes antes do ataque, o pequeno anfíbio contrai suas patas e se joga no precipício. Ele escapa. Centenas de metros abaixo, ele se abre e pode voltar a viver. O sapinho imita as pedras. Ele imita a forma das pedras mas não só. O mimetismo aqui é também de ação, a pedra que rola a montanha, que provavelmente ele, enquanto espécie, viu rolar por todo o tempo.

Partindo de observações e teorias dos processos miméticos entre os animais e o meio, Caillois aventa um outro porquê para os fenômenos de imitação na natureza: o esvaziamento de si, deixar se levar pelo que está ao redor, como um processo de psicastenia promovido pelo meio, no qual a idéia de causa e consequência, e mesmo aleatoriedade, cairiam contra a própria lógica do afetar, se deixar levar. Não há qualquer coisa assim no mundo? Passo um tempo me perguntando se essas observações de Caillois não devem ser lembradas quando pensamos o comportamento, os desejos e as relações com os modelos postos do contemporâneo. Passo por uma esquina, ouço a música pop em primeiro lugar nas rádios, volto pra casa, entro no banho e balbucio o refrão. Percebo muito tempo depois, quando percebo. 
Talvez ${ }^{21}$ a psicastenia seja um sinal dos tempos. Pode participar da condição mimética um impulso de vida visando maneiras de sobrevivência e reprodução. Contudo, o que apresento aqui através do ensaio de Roger Caillois é a mistura do entorno, a convivência comum atravessando o meio, para além das comunicações que damos conta de compreender. Hoje: o digital, as telas, os pixels de hoje, sua onipresença nos celulares, banners digitais, computadores não podem ser vistas apenas como reproduções de realidades ausentes. Ou seja, o conteúdo que é veiculado em todas estas telas, desrespeitando o sentido de proximidade e distância, é assimilado através da presença que produzem enquanto materialidade da tela e do seu meio, digital. E o digital, ao meu ver, a maneira como ele vem participando da nossa vida, age de modo análogo ao psicastênico, as milhões de imagens que temos acesso antes de nos trazer informações e posições, nos colocam no balaio do tempo, elas formulam nossa experiência de vida que foge do controle e nos tornam mais digitais, assim como o digital se torna mais humano quando os pixels usam de lentes e representam o corpo humano. O conceito de pós-história, a revolução da informação proposta por Flusser tem algo com isso. ${ }^{22}$

${ }^{21} \mathrm{O}$ talvez que tanto aparece quando temos dúvida e que Nietzsche desdenha da filosofia do seu tempo, os filósofos que não são filósofos por começarem seus discursos nesta palavra.

${ }^{22}$ Mas não vou continuar por esse caminho pelo desvio e por falta de estudo. 
III

Minha pesquisa sobre os animais que trazem os processos miméticos para sua própria morfologia continuou, encontrei alguns textos mais sobre eles, mas um em especial: Phasme do Geroges Didi-Huberman. É um livro não traduzido para o português, de 1998, uma coletânea de ensaios. Phasme em francês é o nosso bicho-pau. Carrega no nome, vindo do latim Phasma, fantasma, o caráter da sua aparição. É o inseto que vive em parecer outro, árvore, galho, vive em ser inanimado, quando visto vem como aparição, surgimento. $\mathrm{O}$ livro começa pelo ensaio O paradoxo do bicho-pau, no qual o autor chega até a citar, de passagem, o estudo de Caillois. Ele começa a se interessar pelo animal mimético. Vai até o Vivarium de Paris. Lá encontra os bichos-pau em terrários. Tira fotos, as coloca no ensaio. Ele pensa o bicho-pau como o modelo que, de tanta perfeição, até se perde na folhagem. Psicastenia legendária?

Tento seguir esses passos e recebo em troca, por talvez muito querer imitar, o Vivarium de Paris desfalcado de phasmes. Dias depois, triste por não conseguir encontrar o inseto, recebo de amigos que moram no interior, depois de ter conversado com eles sobre o assunto, uma foto de um bicho-pau em um galho. Não sei se eles estão brincando comigo ou se é a perfeição: não vejo nada na foto. Pergunto a eles e não tenho resposta. 


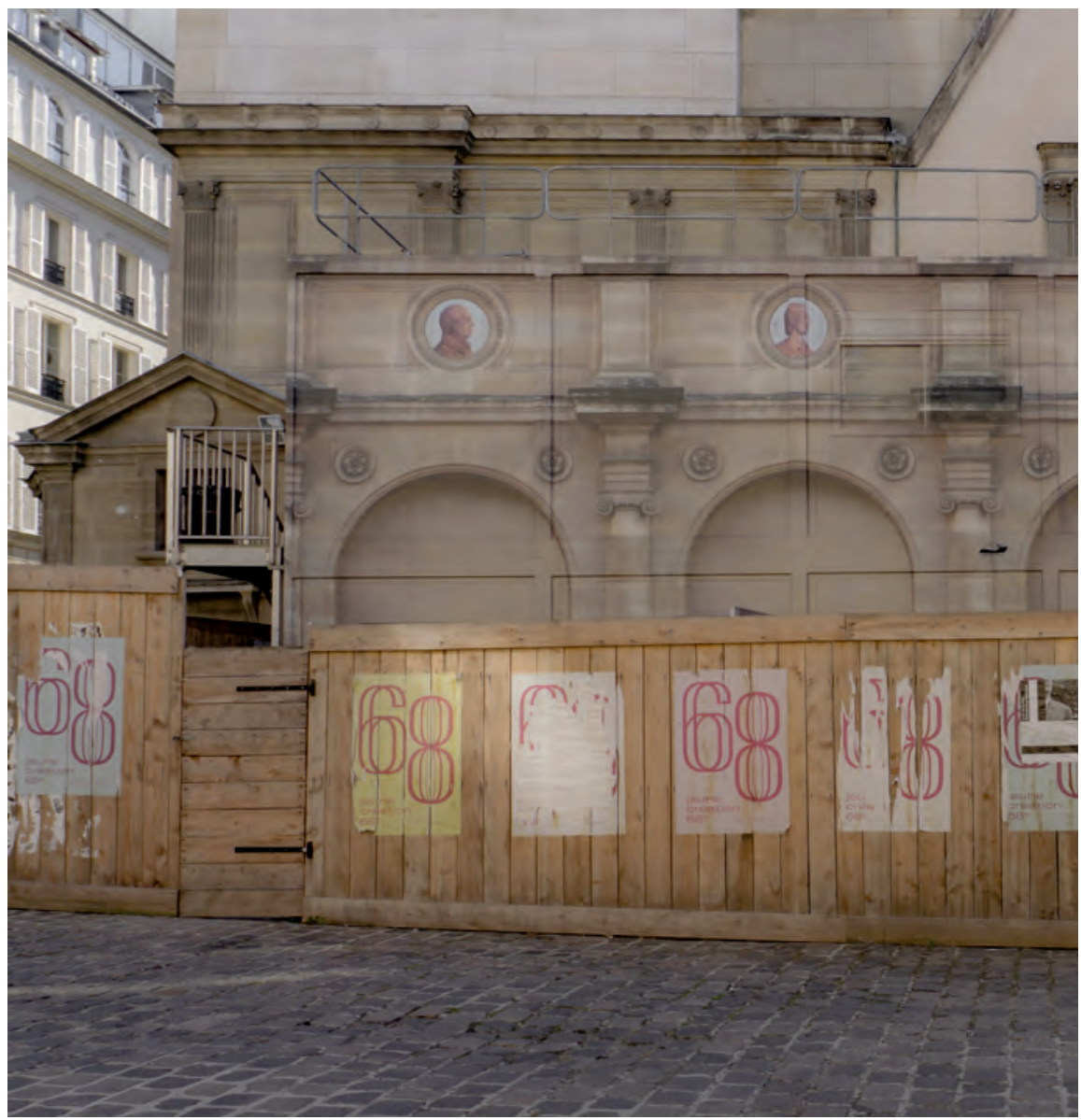




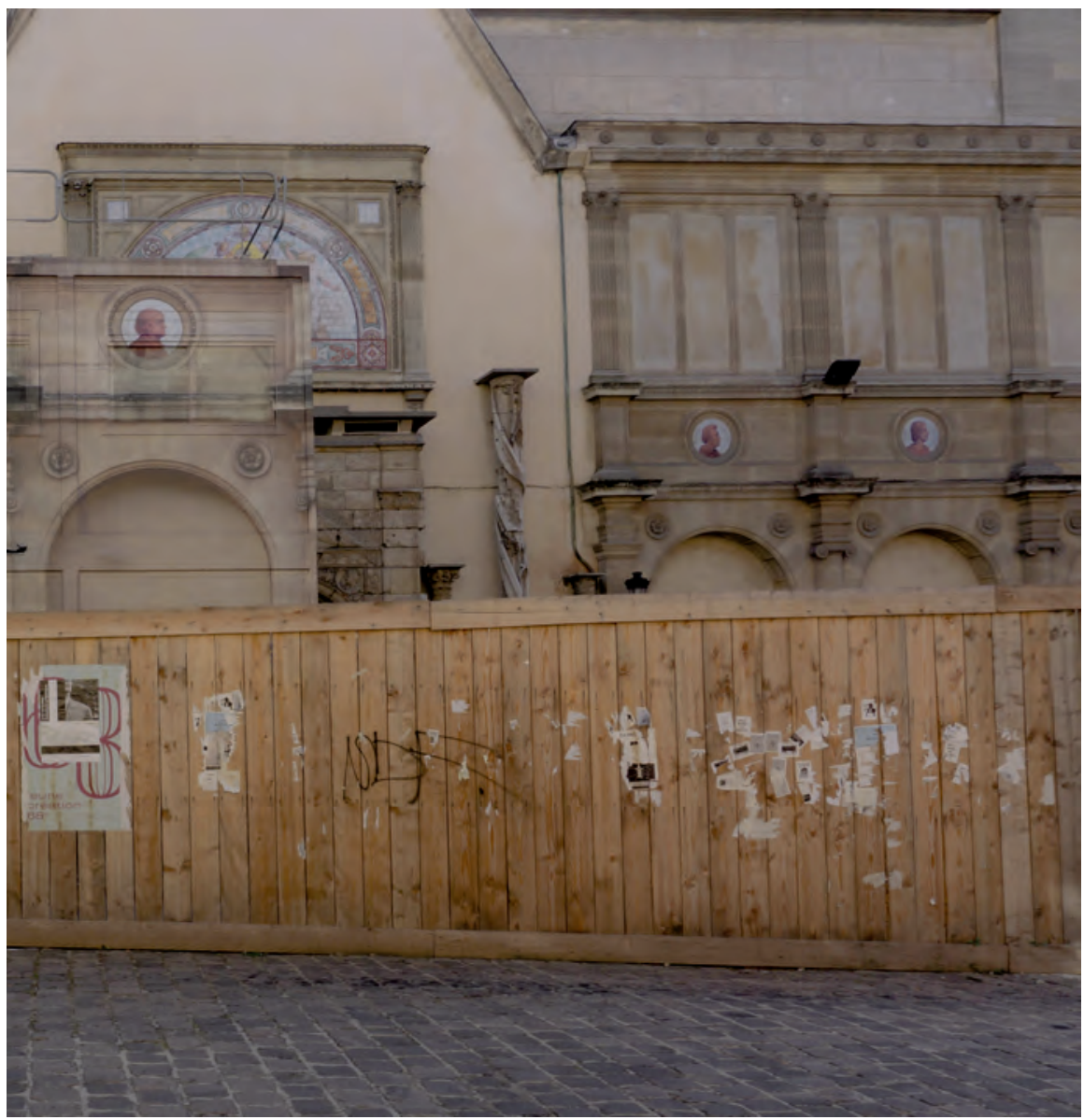


Meses depois, inverno, desistido, ando sem direção, passo por uma loja de venda de insetos. Entro. Estão lá, agora à venda, muitos bichos-pau. Contradição? Vejo a vitrine e não encontro nenhum inseto. Passa o tempo e eles vão aparecendo. Eles já estavam lá e é só coisa do olho acostumar, ou eles vacilarem um movimento que denuncia a vida. Em poucos segundos passam de zero a vinte, tudo que era galho ganha vida. Tiro uma foto ou outra e sem palavras, sem comentários somados às fotografias, só eu saberia que eles estavam ali. A observação mimetizava ali o tempo da terra, a aparição de um bicho-pau era uma possibilidade de ver a vida surgindo, a separação e o laço entre as irmãs fauna e flora.

Didi-Huberman deixa a pergunta no ar: não poderíamos dizer, ao contrário, que nós temos aqui o animal mítico de todo platonismo, pelo qual o modelo verdadeiramente assumido, digerido, forneceria a mais perfeita ilustração do poder da idéia? ${ }^{23} \mathrm{E}$ eu me pergunto: não seria por aí um caminho para dissolver a dicotomia mimesis e simulacro? Não seria neste se deixar levar do tempo e da convivência, que o mimetismo alcançaria seu maior grau, em se fundir justamente com o simulacro na produção de meios que se afetam, se copiam, enganam, constroem dúvidas, invisibilidades e aparições?

${ }^{23}$ Phasme, p. 18-19 


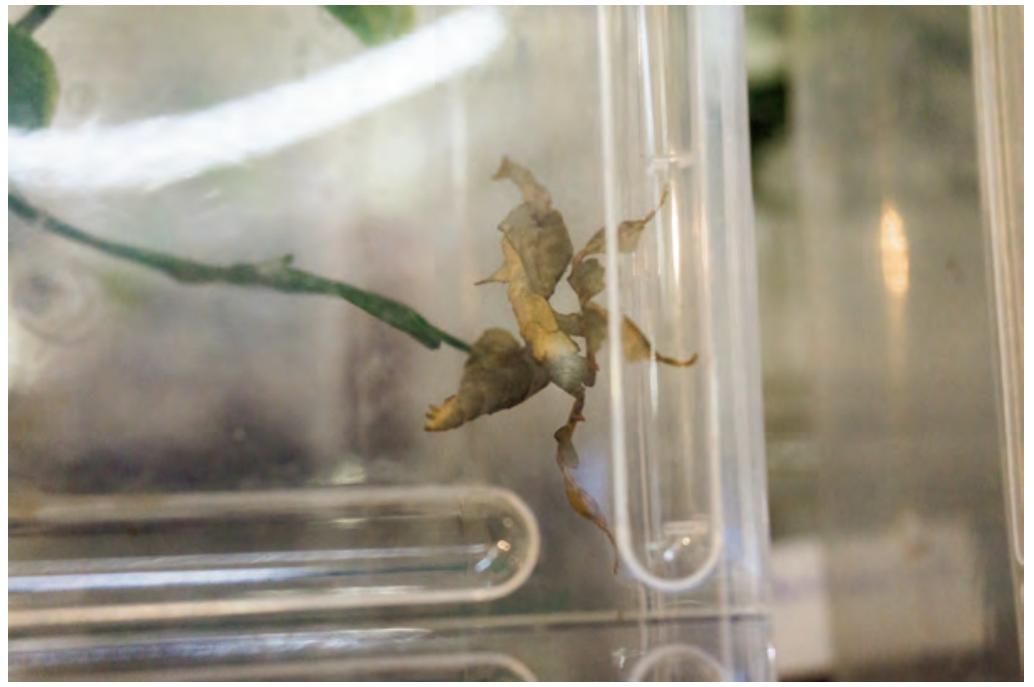




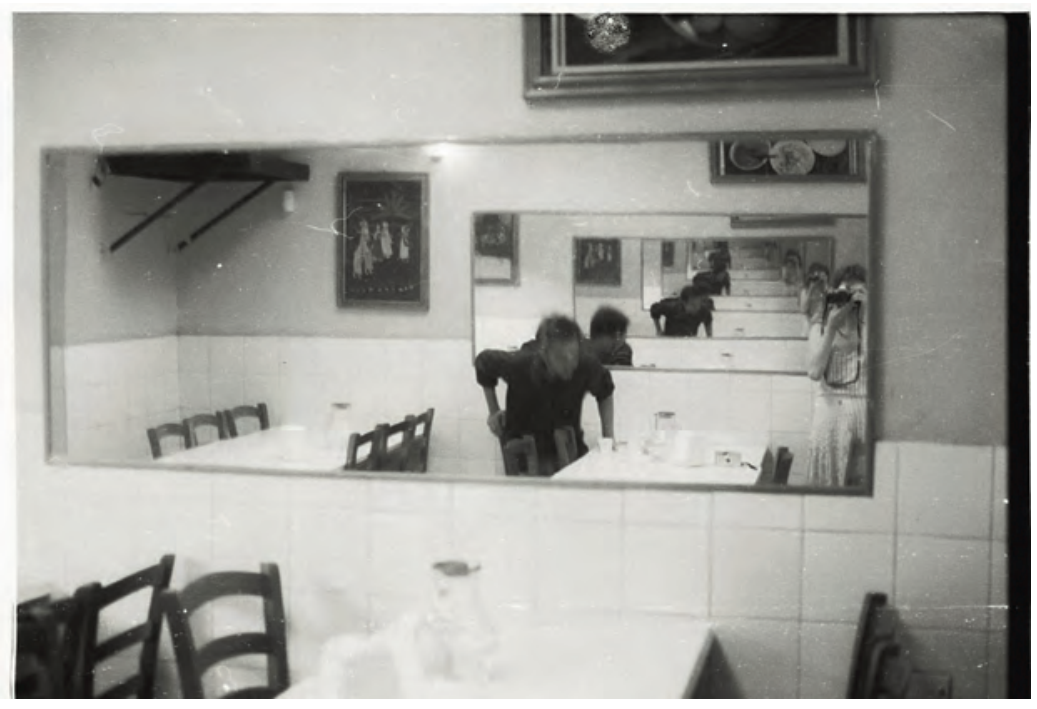




\section{monaísa}


...como disse nosso Botticelli, que tal estudo era vão porque bastava jogar uma esponja embebida de diversas cores sobre uma parede, para que ela deixasse sobre essa parede uma mancha onde se podia ver uma bela paisagem. É bem verdade que se pode ver em tal mancha diversas composições do que se quer aí buscar, ou seja, cabeças humanas, animais diversos, batalhas, rochedos, mares, nuvens e bosques e outras coisas semelhantes; é como o som dos sinos, nos quais podes ouvir o que quiseres.

Tratado da pintura, Leonardo Da Vinci 


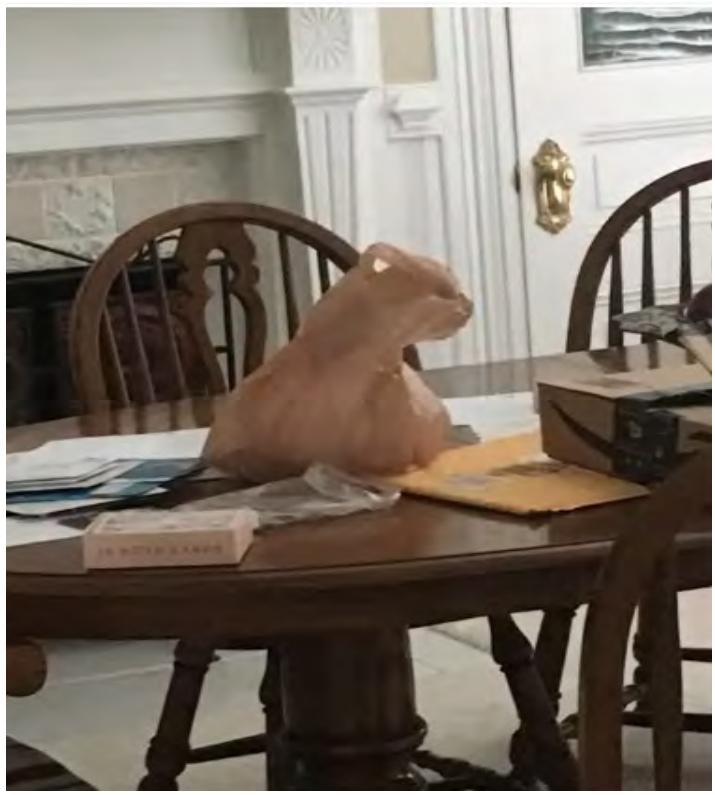


Hoje, visitando o museu do Louvre, me deparo com uma pintura de 1508, chamada Santa Verônica, do pintor italiano Lorenzo Costa. Nela vemos o santo sudário nas mãos de Verônica. Na imagem aparece o rosto, quase sem opacidade no pano, representando o que seriam as marcas de suor e sangue de Cristo. $\mathrm{O}$ pano tem apenas alguns traços que logo percebemos ser um rosto humano.

A pintura fica no grande corredor de pinturas italianas renascentistas. Adiante é a sala da Monalisa. Paro em frente à Santa Verônica e me pergunto da semelhança entre o rosto que se forma no tecido que ela porta e o rosto da Monalisa. Melhor, antes de uma pergunta seria uma intuição, uma verdade? O sentimento descontrolado.

Digo e me digo, reparando nas datas, guardando na cabeça os títulos, que em algum momento pesquisaria aquele mundo até então conhecido somente na superfície. A idéia passou, voltei a outros textos, outros assuntos que me intrigavam. Depois de assistir a um filme em casa, terminado de madrugada, sem sono, ando para todos os lados do único cômodo tentando descansar a cabeça e ver se seria possível dormir. Não era. Vejo os jornais do 
Brasil, é o dia seguinte às eleições. É isso que mais me destrói. Caio em insônia, imagens atrás de imagens. Imagens atrás de imagens.

Já na alvorada pesquiso sobre os dois quadros. As datas são próximas: 1508, Lorenzo, entre 1503 e 1516, Leonardo. Aparentemente, em 1503, Da Vinci recebe como encomenda pintar Lisa Gherardini, mulher de um rico comerciante de Florença. Tinham já dois filhos e mudam de casa. Então procuram um grande pintor da época para fazer o retrato para decorar o novo lar. O quadro nunca chegou a ser entregue e Da Vinci nunca recebeu o pagamento. Há suspeitas de que o quadro não estava de acordo com o esperado. Dizem também que Da Vinci nunca chegou a mostrar a pintura à família Gherardini.

Daniel Arasse, crítico especialista em História da Arte do Rinascimento, sugere que alguns detalhes do quadro podem ter trazido desconforto para a família dos Giocondo. Dentre eles estaria a paisagem no fundo do quadro, diferente do gosto da época, afeito à pradaria, flores e árvores agradáveis. Leonardo, ao contrário, cria uma paisagem selvagem, de alguma forma pré-histórica. Neste fundo, a única presença humana se dá por uma pequena ponte ao lado direito do quadro. Arasse diz que a ponte sobre o rio significaria a passagem do tempo, se valendo 
da imagem do rio, presente desde a antiguidade, como símbolo do tempo que passa ${ }^{1}$. Outro ponto fundamental seria o sorriso de Monalisa. À época, raros eram os sorrisos na História dos Retratos. Arasse propõe que este seria, na realidade, o primeiro sorriso direto para o quadro ${ }^{2}$, em consonância com a proximidade de Gioconda - Leonardo quebra a distância entre o pintor e o representado, tirando o parapeito da tradição flamenca, em voga no século quinze-dezesseis. $\mathrm{O}$ sorriso não era a maneira como Lisa desejaria ser figurada, não continha a austeridade de um quadro a ser posto na sala da nova casa. O último detalhe apontado pelo historiador é a falta de sobrancelhas, o que na época era comum entre as prostitutas ${ }^{3}$.

Não faltam comentadores da História da Arte com trabalhos sérios

1 "Ninguém pode entrar duas vezes no mesmo rio, pois quando nele se entra novamente, não se encontra as mesmas águas, e o próprio ser já se modificou. Assim, tudo é regido pela dialética, a tensão e o revezamento dos opostos. Portanto, o real é sempre fruto da mudança, ou seja, do combate entre os contrários." Heráclito

${ }^{2}$ Arasse relembra do quadro de Antonello de Messina, Retrato de um marinheiro desconhecido, 1470-72. Contudo ele diz que este retrato de Messine é um raté et grimace. Para resgatar a época, Antonello e Leonardo se encontraram em Milão, se conheciam, pintaram sorrisos. Gioconda sorri e olha para o retrato porque seu marido está lá, porque ela tem dois filhos saudáveis e acaba de se mudar, diz Arasse.

${ }^{3}$ Há um outro quadro, no museu do Prado em Madri, que seria uma cópia de ateliê a partir da Monalisa. Lá a retratada tem sobrancelhas. 
e extensos sobre Leonardo Da Vinci e, mais precisamente, sobre a Gioconda. Escolhi trazer os apontamentos de Arasse por sua postura frente à arte, expressa em seu texto Cara Giulia, presente na edição portuguesa de alguns de seus escritos, intitulada Não se vê nada, descrições. Em tom de litígio, esse texto-carta é escrito após Daniel ter ouvido uma apresentação de Giulia, também grande conhecedora da pintura italiana, a propósito do quadro Marte e Vênus surpreendidos por Vulcano, de Tintoretto. O que me é caro à sua maneira de se relacionar com a pintura fica claro nesta passagem:

Não pretendo afirmar que os quadros tenham um único sentido, ou que haja apenas uma única interpretação "correta”. Isso é Gombrich que o diz, e tu bem sabes o que penso do assunto. Não, o que realmente me inquieta é essa espécie de cortina (feita de textos, citações e referências exteriores) que em certos momentos pareces querer interpor a todo o custo entre ti e a obra, uma espécie de filtro solar que te 
protege do brilho da obra e te permite preservar os hábitos adquiridos nos quais se funda e se reconhece a nossa comunidade académica.

Era pelo caminho do erro, ou antes, pelo envolvimento direto, um triângulo entre Santa Verônica, Monalisa e meu pequeno delírio que desejaria fundar uma pesquisa diletante. Seu futuro dependeria apenas das possibilidades que cercariam as obras e esta percepção de semelhança entre o véu do Sudário e o retrato pintado por Leonardo.

Até então, desconhecia a grande polêmica em torno da modelo do quadro, vendo sempre a pintura sendo chamada de Monalisa ou Gioconda, o primeiro título em alusão ao seu primeiro nome e o segundo ao seu nome de casamento, vindo de seu marido Francesco Giocondo. Contudo, inúmeras mulheres, ou melhor, pessoas foram reivindicadas como sendo modelo ao longo dos séculos. Cito de passagem os nomes de Isabella de Castella, Bianca Giovanna Sforza, Pacifica Brandini d'Urbin, Isabella Gualandi de Costanza d'Avalos e mesmo seu assistente de ateliê e amigo Salai ou até um autorretrato do próprio Leonardo. Parte dos argumentos que indicam Lisa Gherardini como sendo a Monalisa surgem do texto de Giorgio Vasari, Vite de' più eccellenti pittori, 
scultori e architettori italiani, da Cimabue insino a'tempi nostri, uma série de biografias publicada pela primeira vez em 1550, na qual ao falar sobre Leonardo da Vinci, Vasari atesta ter visto o quadro e relembra que fora feita a encomenda diretamente por parte de Francesco Giocondo, em 1503. Neste texto Vasari confirma que o quadro representava o retrato de Lisa Gherardini. Faz uma breve descrição do retrato que, apesar de conter partes que não se assemelham ao quadro, a alusão ao sorriso deixa poucas dúvidas da referência precisa à senhora Gioconda4.

Contudo, os comentários de Vasari não certificam a ligação entre retrato e modelo. No começo do século dezesseis, Da Vinci recebia diversas encomendas e, por mais que se tenha notícia do pedido de Francesco Giocondo, não há certeza da conexão. Uma outra possível referência ao quadro data de 1517, mais próxima da feitura do quadro do que o texto de Vasari, quando Leonardo

${ }^{4}$ Muito embora Vasari cite em sua passagem as sobrancelhas da pintura, justamente elas ausentes em Monalisa. Guardo a passagem de especial interesse: [...] e enquanto Leonardo a retratava estimulou que tocassem e cantassem para ela, que bufões a mantivessem alegre para retirar aquela melancolia que a pintura faz nos retratos. Esta figura apresenta um sorriso misterioso tão agradável que era mais divina que humana e era considerada estupenda por não estar de fato viva. Tradução Fernanda Marinho, p. 422 Vida de Leonardo da Vinci, de Giorgio Vasari, Le vite di più eccellenti pittori, scultori e architettori. 
já estava na França. Ela vem de Antonio de Beatis:

Depois da refeição, deixamos Tours, onde estávamos desde o começo do mês, para ir a Amboise, a sete léguas de distância [...]. Íamos fazer uma visita, em um dos burgos vizinhos, ao mestre Leonardo da Vinci, fiorentino, já com mais de setenta anos, excelentíssimo pintor da nossa época, e que mostrou três quadros a nossa senhoria, um de uma certa dama fiorentina, feito a partir da modelo, à pedido do finado Magnífico Iuliano de Medici, um outro do São João Batista jovem, e um da Madona com a criança sentada sobre os joelhos de Santa Ana, os três são de uma rara perfeição [ou são perfeitamente

${ }^{5}$ Este trecho aparece no texto A história francesa dos quadros de Leonardo da Vinci, de Laure Fagnart. Nele, a autora tenta entender como, afinal, os quadros passaram ao poder da família real francesa e, depois, para o Louvre. A pesquisa é interessante, passa pela análise do testamento de Leonardo e de Salai. tradução minha. 
É provável que o quadro citado, da senhora fiorentina, seja de fato a Monalisa, contudo se coloca como um pedido de Iuliano de Medici, o que faz pensar que o quadro em questão tenha desaparecido. As informações são esparsas, se esbarram, se contrapõe. $\mathrm{O}$ texto original em fiorentino tem como passagem, citando a possível Monalisa, uno di certa donna firentina, facto di naturale. A expressão facto di naturale trouxe interpretações para um quadro de uma mulher nua, pois a expressão di naturale era usada na época como nudez. Porém era também usada para dizer que uma pintura havia sido feita a partir de um modelo. Esse problema de compreensão me levou ao desenho que hoje é intitulado A Gioconda nua.

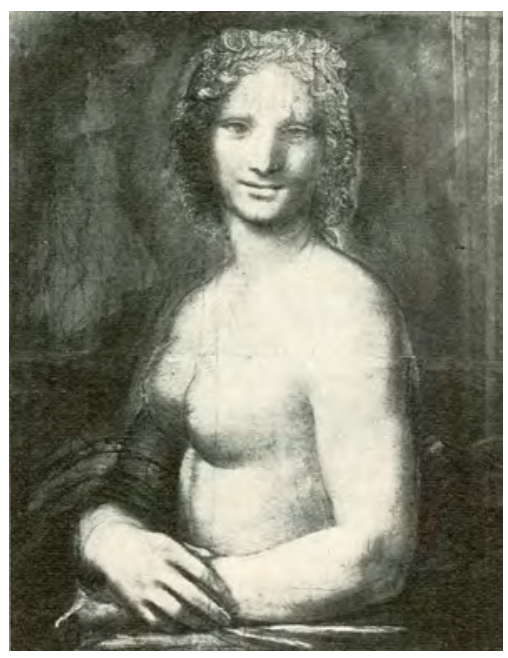




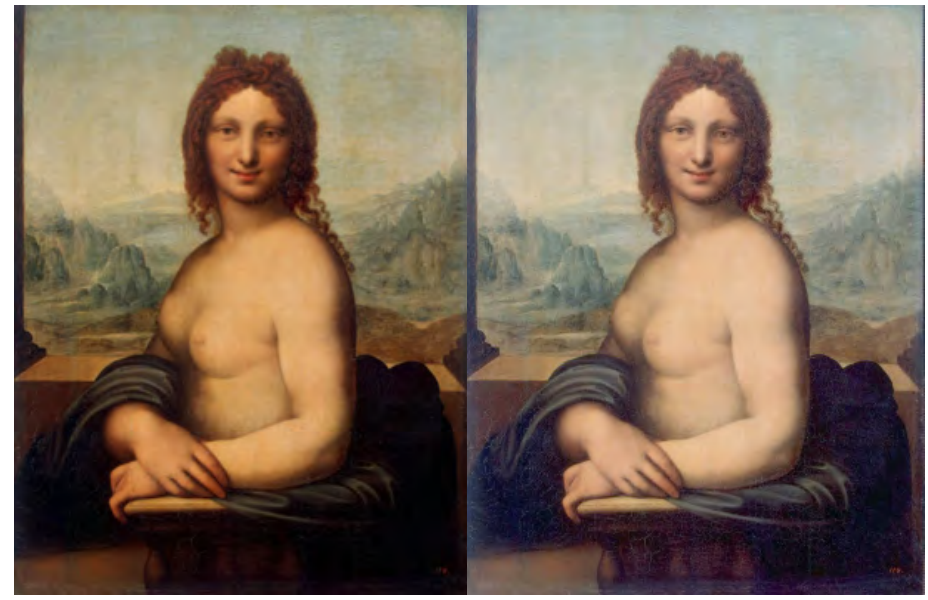


Coloco duas reproduções digitais do mesmo quadro pois elas são muito diferentes, desde a cromática e o contraste, até o enquadramento. Dele tiro dois comentários: o primeiro em relação à Monalisa: a semelhança do fundo nos faz pensar que o quadro foi pintado a partir da obra prima de Leonardo. Notem que além da paisagem azulada do fundo - amarelada na segunda -, a cadeira e as pilastras da esquerda e direita são "as mesmas" da Gioconda. A imagem ao lado do quadro de Da Vinci é uma cópia de ateliê da mesma época, feita possivelmente por Salai e outros aprendizes. O outro apontamento é da semelhança com o rosto de Salai na Gioconda nua. Coloco aqui dois quadros de Da Vinci que tiveram Salai como modelo:

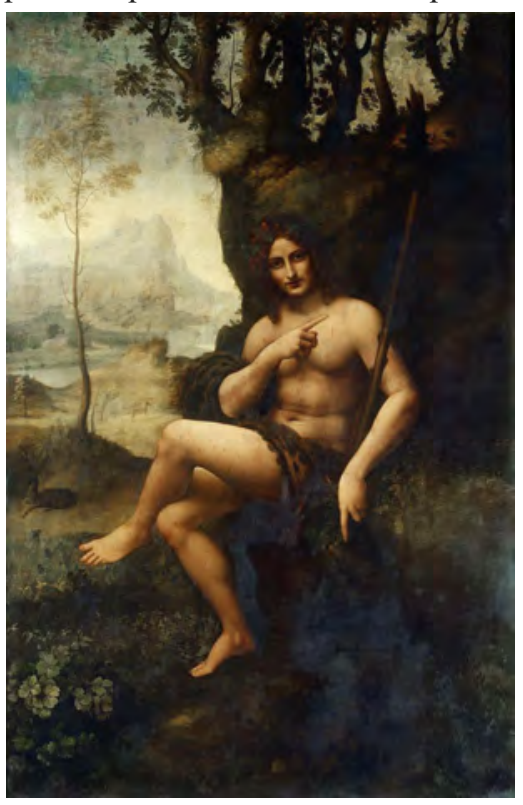




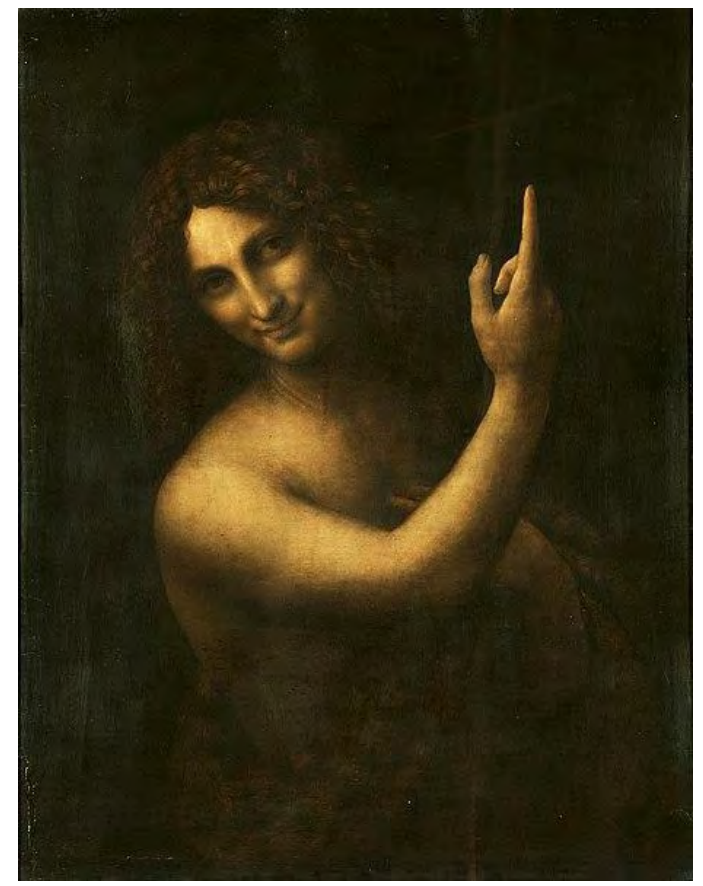

Não há semelhança entre o São João Batista e a Gioconda nua? Os rostos pintados vão se sobrepondo ao infinito. 
A dúvida inicial, partindo do princípio de que os quadros teriam algum contato, era se Lorenzo havia feito o rosto no véu conhecendo o quadro de Da Vinci ou se ambos partiram da mesma modelo. Como o quadro de Da Vinci aparentemente não foi posto à vista durante a vida do pintor, continuei procurando resposta entre as possíveis modelos.

Encontro um elo possível. Uma personagem histórica, protagonista no renascimento italiano. Isabella D'Este. Conhecida por toda a Itália, morava em Mantova, onde era casada com o Duque Francesco I. Isabella era apreciadora da arte, tendo feito encomendas para os principais pintores da época, como Pietro Perugino, além de ter como pintor da corte, Andrea Mantegna e, após a morte deste, em 1506, Lorenzo Costa. Leonardo da Vinci, em 1499, em viagem de Florença a Veneza, passa por Mantova, onde faz um desenho de Isabella D’Este.

Este é o retrato de 1499 de Isabella D'Este desenhado por Leonardo da Vinci. Coloco aqui duas reproduções digitais diversas, uma recortada, com forte contraste e saturação e com a deformação da lente corrigida. $\mathrm{O}$ outro não. $\mathrm{O}$ desenho foi feito em carbono, produzindo duas cópias. 
Uma delas ficou em Mantova, a outra, Da Vinci levou consigo. É este desenho em posse do pintor que Isabella chega a comentar querê-lo pintado, mesmo que sem os detalhes da paisagem. É também neste momento que é encomendada uma pintura de D’Este à Da Vinci, a princípio, nunca realizada.

Lorenzo Costa quando chega a Mantova como pintor da corte, fica responsável por finalizar uma tela, Isabella D'Este no reino da Harmonia, começada por Mantegna e interrompida por sua morte. A pintura deveria figurar no Studiolo de Isabella, um cômodo dentro do palácio reservado aos seus estudos e produções. Isabella era uma exímia musicista.

Outras obras decoravam o Studiolo, como Triunfo da Virtude e Parnasso de Mantegna, Luta entre o amor e a castidade de Perugino e Reino de Como, de Lorenzo Costa. Todas as telas estão expostas no Louvre, assim como o desenho-rascunho apresentado acima.

Voltando ao quadro Isabella D'Este no reino da Harmonia, pensa-se que Isabella foi modelo para o quadro. É ela que está recebendo a coroa de louros de Anteros, o Deus do amor retribuído 

Ela está de vermelho e branco, na altura central da tela à direita ${ }^{6}$.

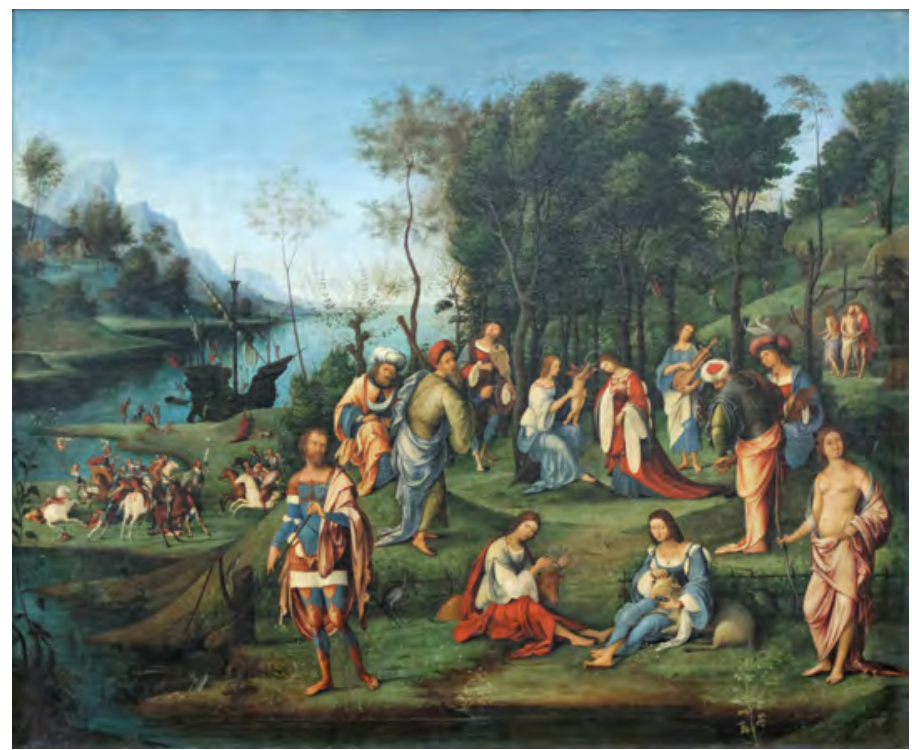

Sabemos da passagem de Da Vinci por Mantova por cartas trocadas entre Isabella e o pintor, geralmente por meio de um intermediário, como Pietro da Novellara ou Malatesta. Ao primeiro, sem saber o exato paradeiro do pintor, Isabella pede que chegue até ele o pedido para fazer uma versão pintada do desenho em carbono (o desenho de perfil), sem a necessidade de detalhar o

${ }^{6}$ Para ver a imagem em grande resolução: https://it.wikipedia.org/wiki/ Isabella_d\%27Este_nel_regno_di_Armonia 
fundo com a paisagem campestre. Da Vinci responde, também por intermediários, dizendo que assim que possível fará a obra. Meses mais tarde, sem mais sinais da realização, Isabella volta a entrar em contato, dessa vez pedindo a pintura de um Jesus jovem. Ela diz querer um quadro de suas mãos para adicionar aos demais do studiolo. Anos depois, sem nenhuma obra, volta a se corresponder, dessa vez por Malatesta, querendo a opinião de Da Vinci a respeito de uma coleção de vasos, os quais pretendia adquirir.

São desencontros que a história deixou registrado ${ }^{7}$. Ela chega a ir a Florença, mas Da Vinci não está lá. Chega a encontrar o tio do pintor, Alessandro Amadori, e reforça seus pedidos por uma tela do sobrinho. Este, como os outros, relembra que Da Vinci está cada vez menos interessado em pintar, e que a geometria tem tomado todo o seu tempo. Anos mais tarde é possível que tenham se encontrado em Milão, quando o pintor já morava na cidade ${ }^{8}$. Lorenzo Costa segue como pintor da corte até sua morte. Lá ele

${ }^{7}$ Site-arquivo sobre Isabella D’Este: http://isabelladeste.web.unc.edu/. Nele estão as cartas transcritas, assim como o fac-simili.

${ }^{8}$ Estas e algumas outras informações a respeito das cartas trocadas através de outros com Da Vinci estão na obra Isabella D'Este Marquise de Mantoue, de Julia Cartwright, de 1912, disponível para download no site da Universidade de Lorraine: http://docnum.univ-lorraine.fr/pulsar/ RCR_543952103_41675.pdf 
desenvolve sua obra, tendo seu trabalho reconhecido por Isabella. Não encontrei comentários da época a respeito de sua tela Sainte Vêronique. A tela é de 1508, o mesmo ano do encontro de Da Vinci com Isabella, em Milão. Até 1506, ano em que Isabella vai a Florença e não consegue encontrar Leonardo, o quadro não teria como ser finalizado.

A hipótese se torna: Lorenzo Costa, pintor da Corte de Mantova, usou Isabella D'este como modelo para o rosto de Jesus no sudário. Ele, que a representara no quadro já apresentado, poderia ter copiado o rosto ou pedido para ela ser modelo in natura para marcar o sutil sombreado da presença de Jesus no sudário de Turim, posto pela igreja como uma das presenças materiais (o pano) da imagem de Cristo. 


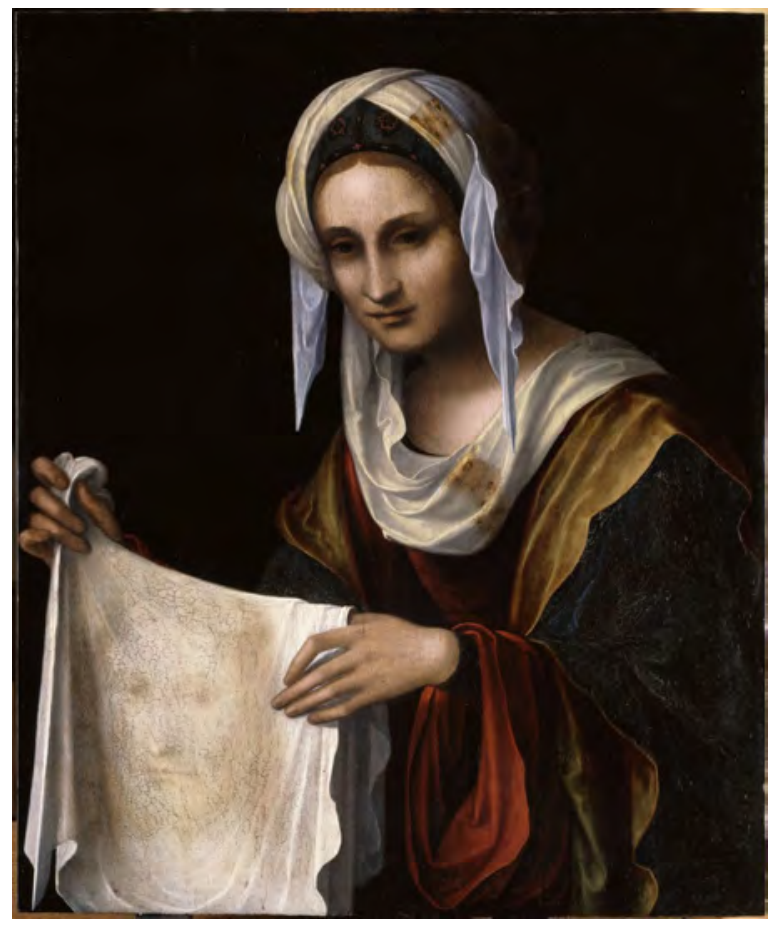


Dentre os interessados pela vida de Leonardo Da Vinci está Freud. Em suas poucas incursões à biografia póstuma, Freud elege Da Vinci se valendo dos quadros e das biografias já feitas para inferir marcas da personalidade do pintor. $\mathrm{O}$ texto tem altos e baixos, no percurso de seus escritos este é lembrado por ser a primeira vez que Freud começa a desenhar o conceito de narcisismo. Mesmo para o autor, o texto passou por transformações. À época da escrita enviou uma carta ao seu amigo e psicanalista inglês Ernest Jones, atenuando grandes esperanças, dizendo que ali não estaria a resposta de nenhum mistério. Mas nove anos mais tarde, escreve à Sándor Ferenczi, psicanalista húngaro e seu colaborador, que lá estavam as únicas coisas belas que havia escrito9 ${ }^{9}$. Vamos ver mais adiante o porquê dos psicanalistas praticamente descartarem este texto da história da teoria psicanalítica.

De saída, Freud repercute a inconstância de Da Vinci em seus trabalhos, deixando muitas pinturas inacabadas e demorando mais do que outros de sua época para finalizar os trabalhos, mesmo os encomendados. Ele relembra o texto de Vassari dizendo que levou quatro anos pintando o retrato de Mona Lisa, a mulher

${ }^{9}$ Didi-Huberman, Une ravissante blancheur in Phasmes. p.78 
do florentino Francesco del Giocondo, sem conseguir dá-lo por terminado ${ }^{10}$, e conclui dizendo que este fato poderia explicar o porquê do quadro nunca ter chegado às mãos da família.

Ele aventa que essa dificuldade de terminar os quadros viria de uma tentativa profunda de precisão, unindo à prática de $\mathrm{Da}$ Vinci a frase que muitas vezes é rememorada quando lembrado o pintor, la pittura è cosa mentale. A materialidade da pintura não daria conta de tudo que se passa no mundo das idéias e, portanto, o inacabado é de uma só vez a causa e a consequência do trabalho de arte.

Freud toma cuidados maiores que outros escritores de fora do mundo da arte, e até de dentro, trazendo questões próprias à práxis da pintura, como quando fala do afresco da Última Ceia, do Convento de Santa Maria delle Grazie, em Milão:

Leonardo não se podia acostumar ao afresco, que exigia trabalho rápido na aplicação das tintas na superfície ainda úmida e, por isso, preferiu usar as tintas

${ }^{10}$ Freud, Leonardo Da Vinci e uma lembrança da sua infância (1910), p. 42. http://conexoesclinicas.com.br/wp-content/uploads/2015/01/ freud-sigmund-obras-completas-imago-vol-11-1910.pdf 
a óleo, de secagem mais lenta, que lhe permitiam protelar o término da obra de acordo com seu humor e lazer. Estas tintas, no entanto, desprendiam-se do muro e o destino posterior do edifício provavelmente determinaram o que parece ser a ruína inevitável do quadro.

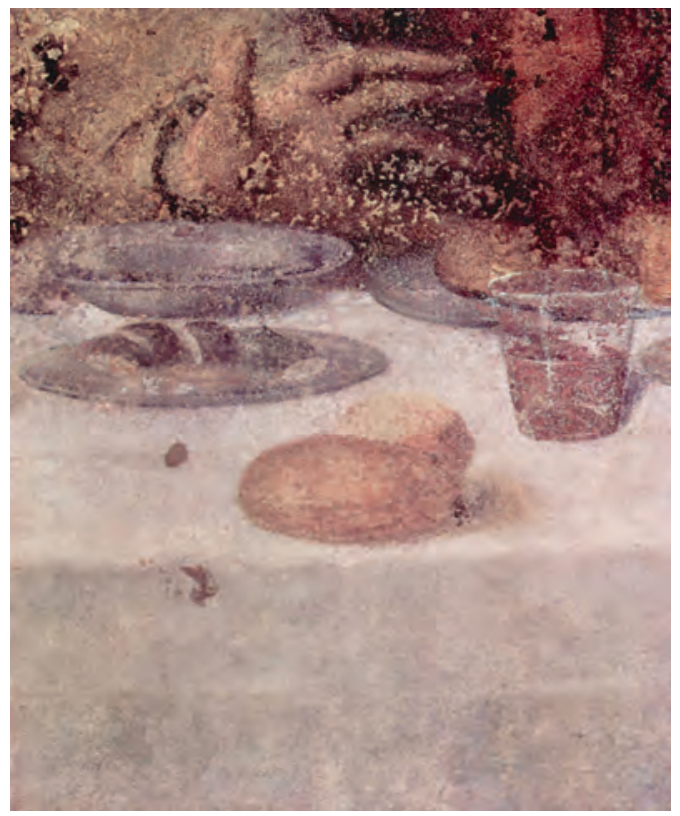

${ }^{11}$ idbem, p. 43 
As contradições da persona de Leonardo são apresentadas quando relembra que o pintor não comia carne e comprava pássaros para libertá-los das gaiolas - o que Freud chama de feminina delicadeza -, mas que acompanhava de perto os últimos passos dos criminosos antes da execução para estudar as feições distorcidas pelo medo ${ }^{12}$.

A dúvida que paira sobre a pessoa-modelo representada no quadro da Monalisa, que aqui se aparece como caminho para desbravar um tempo do mundo e da arte - mas que causa verdadeiros litígios na História da Arte -, evidencia a falta de documentação da parte "extra-arte" dos acontecimentos do Renascimento. No entanto, Freud se dedica a compreender verdadeiramente traços da personalidade de Da Vinci, entender até mesmo sua sexualidade através do que estava escrito em seus cadernos, suas pinturas e dos demais documentos históricos, como cartas e comentários sobre o pintor feitos por outros que conviveram com ele. A psicanálise, que se concentra cada vez mais na maneira como o ser se narra, já presente em Freud como metodologia, o espaço da escuta, não para ouvir a verdade, mas para ouvir como o paciente se entende consigo e com o mundo, perde espaço para um mundo de especulações. Tenho uma nota de caderno de quando li o texto de Freud pela primeira vez: Freud se abre para que o analisemos

${ }^{12}$ Esta é verdadeiramente uma contradição? idbem. p.43 
através do desejo de compreender Da Vinci.

É duvidoso que Leonardo tenha jamais abraçado uma mulher com paixão ${ }^{13}$. Ressalto apenas uma ou outra frase do texto de 1910 que impressiona o leitor de hoje.

Freud se aproxima do seu motivo principal quando começa, na metade do texto, a falar sobre a infância: depois de examinar a possível falta de interesse de Da Vinci nas relações sexuais, nos traz parte de seus conceitos sobre a sexualidade, dizendo que este instinto é dotado da capacidade de sublimação: é passível de ser trocado por objetos desprovidos de caráter sexual e que possam ser mais altamente valorizados ${ }^{14}$. Coloco esta parte para ressaltar os pontos positivos do texto, que são muitos, e não parecer que há desdém com o autor. Considero, como diletante nas pesquisas psicanalíticas, que Freud é um dos autores mais importantes do século XX, em especial pelo caráter literário de sua obra, sempre muito bem escrita e profunda em sinceridade.

Passo aqui para a memória estopim de toda a crítica que recebe este texto e que até pouco tempo foi pouco mencionada ${ }^{15}$ : a recordação de Da Vinci, quando ainda criança de berço, sendo vi${ }^{13}$ Ibdem. p. 45

${ }^{14}$ Ibdem. p. 48

${ }^{15}$ Ibdem. Nota da tradução brasileira, p.38 
sitado por um pássaro. Aqui Freud cita Leonardo: [...] como uma das minhas primeiras recordações que, estando em meu berço, um abutre desceu sobre mim, abriu-me a boca com sua cauda e com ela fustigou-me repetidas vezes os lábios $^{16}$.

Freud duvida de primeira da realidade dessa recordação, tanto pela cena quanto pela idade que Leonardo tinha quando do ocorrido. Ele joga a história para o campo da fantasia. E se estamos falando de uma fantasia rememorada por Da Vinci já adulto, seria difícil discernir esta imagem como verdadeiramente da infância: sendo ela uma produção de Da Vinci do agora colocando a cena no passado. Freud começa sua análise: A cauda do pássaro já vinha sendo usada como um dos símbolos familiares para o órgão sexual masculino, o que transformaria este ato relembrado em uma fellatio17. Na sequência relaciona também a cauda na boca ao ato da lactância, o que Freud remete naturalmente à relação entre Da Vinci e sua mãe, ausente desde cedo em sua vida. Freud se pergunta: De onde veio esse abutre e por qual motivo aparece nesse lugar ${ }^{18}$ Ele resgata o mundo egípcio cujo o hieróglifo da mãe era representado pela imagem de um abutre. Mas ele ${ }^{16} \mathrm{Ibdem}$. p.51. Freud diz que este trecho estava escrito em um dos cadernos científicos de Leonardo.

${ }^{17}$ Uso das palavras empregadas por Freud que, na sequência, pede ao leitor paciência para não cair em questões morais, o que talvez seja um comentário importante para o começo do século XX.

${ }^{18}$ página 54. 
descarta a possibilidade de Leonardo saber disto, visto que foi François Champollion que os desvendou e viveu dois séculos depois do pintor. Mas o mundo egípcio era motivo de estudos muito antes, já desde os gregos e romanos, e que por estas fontes ficamos sabendo que o abutre era considerado um símbolo da maternidade, pois acreditavam que somente havia abutres do sexo feminino ${ }^{19}$. E após conexões entre a publicação de livros antigos e Milão, uma das cidades líderes na arte de imprimir, onde Leonardo passou boa parte de sua vida. E se os abutres, segundo os melhores testemunhos da antiguidade, dependiam do vento para serem fertilizados, por que não teria, alguma vez, acontecido a mesma coisa com uma mulher?20. Segue assim Freud com a certeza de que Da Vinci sabia desta ligação entre os abutres e as mulheres advinda da cultura do Egito Antigo, passada através de algum livro de um padre ou compêndio de história natural. E ele, que teve mãe, mas não teve pai, estaria na rotação do signo do abutre. A análise é encantadora. O texto de Freud impressiona não pelas coincidências, mas pelas diversas fontes que o autor foi buscar para criar uma narrativa, ultrapassando a própria fantasia de Leonardo.

E sentencia: a substituição de sua mãe pelo abutre indica que a criança tinha conhecimento da ausência do pai e se sentia solitá${ }^{19} \mathrm{ibdem}$.

${ }^{20}$ ibdem. p. 55 . 
ria junto à sua mãe. $\mathrm{O}$ nascimento ilegítimo de Leonardo confere com a sua fantasia sobre o abutre; somente debaixo desse aspecto poderia comparar-se a um filhote de abutre ${ }^{21}$. E se as demais biografias aferem que Leonardo foi cuidado por seu pai a partir dos cinco anos de idade, sem termos informações sobre a mãe, Freud consegue nos assegurar que esta sua primeira infância, através da imagem da descida do abutre ao berço, certamente foi ao lado de sua mãe. Ele. A mãe. O abutre.

Não vou me alongar nas explicações freudianas, mas no texto sobre Leonardo ele traz cada vez mais detalhes que comprovariam que esta visita do abutre é símbolo marcante do que viria a se tornar o Leonardo por nós conhecido. Há ainda um último detalhe a ser observado, este não menos impressionante, quando Freud volta à obra do pintor para mostrar traços da fantasia já em sua produção artística . Estes traços estão presentes no quadro A virgem e o menino com a Santa, pintado em Milão, entre 1508 e 1513, e que hoje faz parte da coleção dos pintores do Renascimento italiano no Louvre. Para além das interpretações feitas sobre a possível metáfora dos personagens serem ele mesmo quando criança, sua mãe como virgem, Freud nota o véu azul do quadro sobre as pernas da virgem, sentada no colo da mãe Sant'Ana: Ali está o abutre perseguido!

${ }^{21}$ ibdem. 


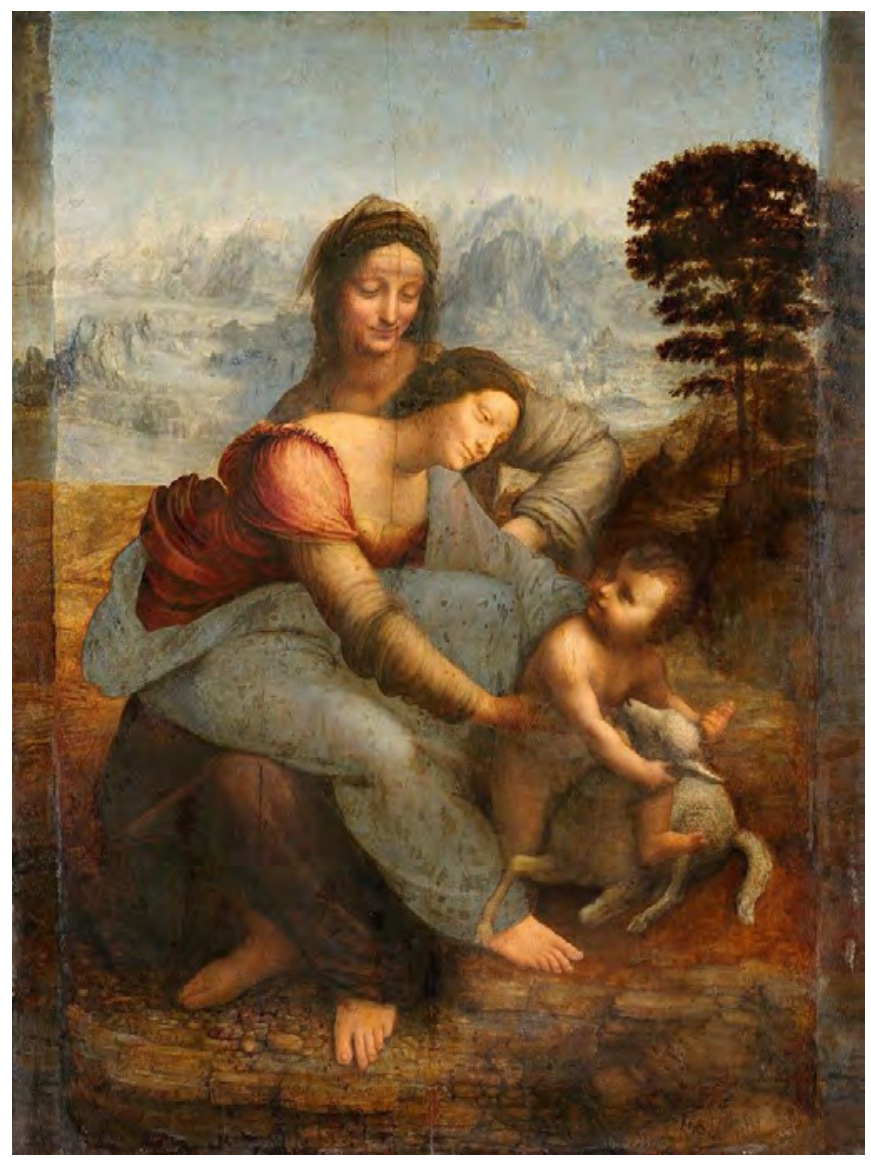




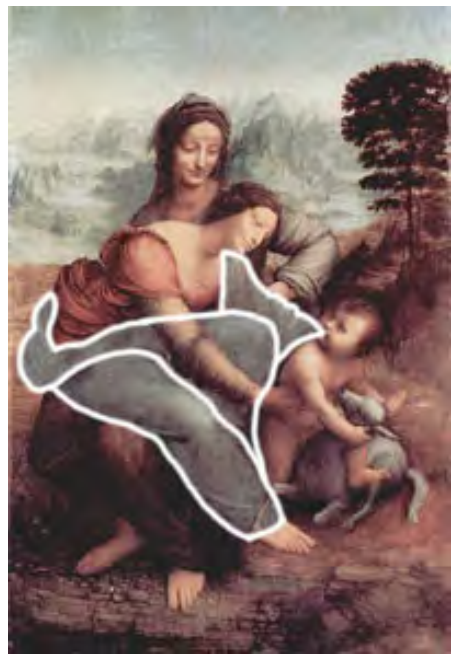


O texto de Freud segue, inclusive é ele que repara neste mesmo ensaio, que depois de Monalisa, Da Vinci e seus alunos passam a pintar as mulheres dos quadros com pequenos sorrisos na boca. Fico por aqui, trazendo o que finalmente mais me interessa no texto: um erro de tradução de Freud quando traduz a palavra em italiano nibbio por abutre. Nibbio seria outro pássaro, o milhafre. Eles não são muito diferentes, mas este erro levou Freud à toda sua pesquisa e investidas em colocar em Da Vinci conexões da fantasia do berço com a cultura do Egito Antigo. Tudo que foi dito se desfaz? 


\section{IV}

Estamos na mesma. Vemos o que estamos propensos a ver, no escopo das nossas capacidades físicas, e com um desejo de assimilação voraz, de trazer para perto, de reconhecer. Como reconhecer algo que é novo? Este novo não será de todo novo porque não temos esta capacidade de colocar de lado nossas impressões, o que está impresso em nós e nos abrirmos para o completamente novo. o novo é uma idéia feita pelo velho que deseja algo mais, que deseja se desgarrar, cruzar a rua, olhar mais detidamente para o conhecido. O abutre do Freud é minha Monalisa no pano pintado por Lorenzo Costa.

Inventaram um nome para isso, é o fenômeno da pareidolia, ato de conseguir ver a imagem de algo já conhecido, um rosto humano nos riscos da parede, um navio por alguns segundos de uma nuvem. É o que fazemos, o que somos capazes de fazer com as imagens: atribuir significados seja do que já conhecemos, seja do que somos capazes de conhecer.

O fenômeno de assimilação vai longe, ultrapassa as formas e vai aos hábitos. Podemos ver árvores mais do que com formas humanas, mas agindo como seres humanos, se abraçando. Temos a capacidade de tudo personificar. Mas não seria melhor ver, 
especialmente nas formas, o princípio atômico de que tudo que aqui está é feito das mesmas moléculas e que há certa tendência de aproximação das formas? Como os troncos que viram braços ou o desejo pela luz por parte dos insetos e nós que a usamos como metáfora da razão, como alguns insetos que também buscam lugares escuros para morrer. E nós que enterramos nossos parentes? Não seriam princípios da natureza? Muitos são os que dizem que, do nosso lugar, da nossa posição, perspectiva, a partir da nossa lógica da língua, não somos aptos a dizer estas coisas. Aliás, depois da linguagem ter alcançado o estatuto de mediador dos desejos e ter se tornado na sequência, por Saussure e Lacan, o nascimento e a morte, o ser humano em si, ganhamos a possibilidade de tudo dizer porque as palavras foram libertas para o infinito e aprisionadas na palavra infinito.

Me lembro de acabar uma amizade por este ato sendo refeito ao infinito por um amigo: tudo o que ele via comparava com algo já visto ou vivido: a escravidão da analogia presente na palavra como, que nos transforma numa miniatura da História. Mas isto pode ser, não de todo, mas revertido pela fórmula: tudo que se diferencia se parece, tudo que se parece se diferencia. Podemos assim, ao olhar, procurar ver as diferenças antes das semelhanças, ou seja, o que há de próprio nos nossos atos, nos distanciando do conforto do sabido e nos jogando ao que não se cansa de variar. 
São as águas do rio de Heráclito.

Me vem a indagação do artista Marco Buti quando debatíamos a respeito das representações das obras de arte. Ele disse: quais de vocês teve acesso, pela primeira vez do olhar, às obras de arte que fazem parte da História da Arte, ou ao menos, da História de vocês da Arte, ao original, à matriz antes das reproduções? Talvez, com sorte, os muito ricos ou os alunos europeus possam ter ido ao Louvre antes de ter visto em uma revista, livro ou internet as reproduções de uma obra-prima. Somos marcados pelas reproduções e não vamos nos deter em refazer frases como: adoro $a$ obra reproduzida em fotografia analógica que vi em uma revista feita em papel jornal da obra do Nicolas De Staël.

Têm obras que fazem parte da grande História da Arte e que mal passam por nós. Algumas descobrimos uma anedota ou motivo para lá estar, mas que estão longe do nosso percurso pessoal, da nossa História da Arte, que hoje é perpassada felizmente por formas e acontecimentos que muitas vezes nem qualificamos como Arte ${ }^{22}$. A Monalisa talvez fosse uma dessas obras, apesar de em 2013 ter estado no Louvre e filmado a cena ritualística de

${ }^{22}$ Como a proporção dos corpos dos jogadores em um jogo de futebol transmitido na $\mathrm{TV}$, miniaturas no campo que assistia com meu pai nas manhãs do domingo e que vejo qualquer aproximação com muitas das minhas fotografias. 
dezenas de pessoas, em frente ao quadro, buscando um lugar entre as cabeças para filmar. Fitar? A selfie ainda era pouco usual, as pessoas tiravam foto diretamente do quadro ou o gravavam para ter uma reprodução em suas pastas de computador. Essa cena me fez começar uma busca por vídeos no Youtube de pessoas filmando e fotografando quadros no Louvre. São imagens interessantes, a maior parte mal enquadram as telas inteiras e mal fixam a imagem o suficiente, ao menos um frame não tremido de vídeo, com o qual um pause traria um fotograma aproveitável da imagem. Estes fenômenos acontecem ao mesmo tempo em que boa parte da História da Arte mais oficial, em especial as obras presentes nestes célebres museus, está reproduzida na internet com grande resolução e aparente fidedignidade. Elas queriam guardar algo daquele dito momento especial, com ditas obras especiais. Se são obras especiais e não se vêem suas diferenças, é melhor capturá-las. Na imaginação ela não vai figurar, é importante ter o arquivo salvo para perdê-lo e assim ter a sensação de contato, poder afirmar que já houve ligação, mas que ela se apagou por desventuras.

Joan Fontcuberta, relembrando Barthes, da idéia do Isso foi, que marcava o fenômeno da imagem como portadora de um instante do objeto frente ao aparelho, diz que a fotografia, com a selfie, começou a ter outro signo imanente do seu ato, seria o eu estive 
aqui. A selfie traria a propriedade da presença ${ }^{23}$. Não acho que este fenômeno já não estivesse presente nas fotografias diretas do quadro: cada um guardando em sua câmera, e depois nas pastas do computador, a imagem que fez . Esta fotografia não é feita para rever o quadro, é mais um signo de contato transformado em matéria, em pixels, números.

Esses vídeos coletados de passeios no museu com a câmera apontada como mediação - o olho sem um aparato entre pessoa e objeto vem se tornando um desafio -, se tornariam parte de um filme que discutiria como o olhar, verbo e sentido usados para atestar a razão, sofre uma fratura, um desgaste quando cansado e superutilizado. O filme, que hoje sei que fará parte daqueles jamais feitos, se colocaria a pensar se há um paradoxo entre o quanto mais se vê, mais se percebe ou o quanto mais se vê, mais se domestica. Voltando à questão da História da Arte ser apreendida através de reproduções, distantes dos originais, também sempre me vem à cabeça como os olhares e formulações são construídos sobre determinados objetos sem, às vezes, termos nenhum contato verdadeiro. Nos cursos de Artes este assunto sempre vêm à tona quando se fala das centenas de trabalhos acadêmicos feitos sobre trabalhos artísticos que descontextualizam a maneira como este foi apresentado, o que significava sua presença no tempo de

${ }^{23}$ Texto que saiu na revista Zum no 11 
sua realização, trazendo anacronismo e distopia para as ideias. $\mathrm{O}$ digital, como mediação central das imagens no contemporâneo, pode ajudar neste se perder de tempo e espaço: fotografias com cem anos de diferença estão na mesma superfície, com a mesma textura que quadros e afrescos, desenhos, gravuras, vídeos e tudo mais o que for possível de se produzir sintaticamente e jogar no Google. Isto não é um ataque às formas contemporâneas de alcance e disseminação das matérias à distância. É um lembrete. 
Anexo:

Monalisa: Foi interessante descobrir, enquanto fazia a pesquisa sobre a possível modelo pintada, que quando roubado o quadro do Louvre em 1911, O inspetor encarregado do caso foi Alphonse Bertillon, o mesmo que havia anos antes inventado o Sistema Bertillon, método antropométrico de tipificação do perfil de pessoas que passavam pela polícia, muito dele ainda usado nas famosas fotos de três por quatro de frente e perfil quando se é fichado atualmente. Neste caso, chegam a prender Guillaume Apollinaire e interrogar Picasso $^{24}$. A racionalidade empregada por Bertillon para os retratos três por quatro criam caminhos, como: um grande pintor da época pode ter roubado um grande quadro. O quadro havia sido roubado pelo vidraceiro, Vincenzo Peruggia, responsável pelos vidros de diversas obras do museu. Sua facilidade de acesso estava na materialidade do que era visto quando se via a obra, mas em transparência. Além disso, o século XIX foi o tempo da consolidação dos Estados-Nações através do nacionalismo. Desenha-se bandeira, cria-se hino. E o vidraceiro era italiano, dizem, queria o quadro no seu devido país. Nos jornais italianos foi saudado pela tentativa - mesmo

${ }^{24} \mathrm{O}$ primeiro por ser suspeito de ter roubado estatuetas do museu anteriormente, o segundo por ter comprado uma das estatuetas e ser um grande pintor da época. As conexões da lógica. 
que não haja certeza de que fora o nacionalismo que o movera ${ }^{25}$-, e o quadro encontrado na Itália foi exposto em Florença e em Roma, antes de voltar ao Louvre.

Também encontrei esta pintura e esta fotografia da época ...

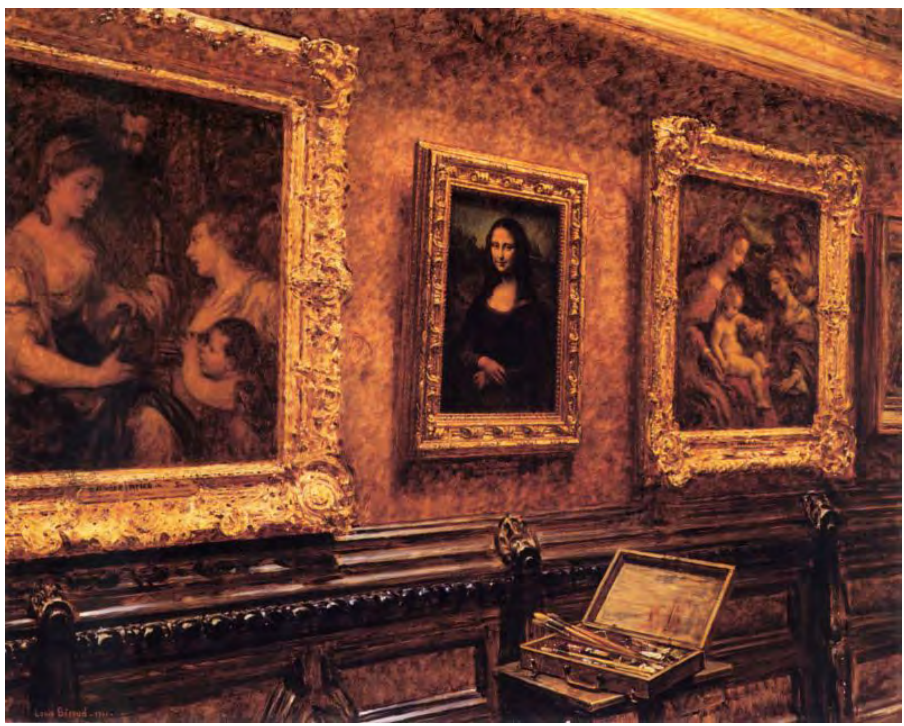

${ }^{25}$ Muitos se valem do nacionalismo para outros fins, a bandeira cobre o focinho e as orelhas. 


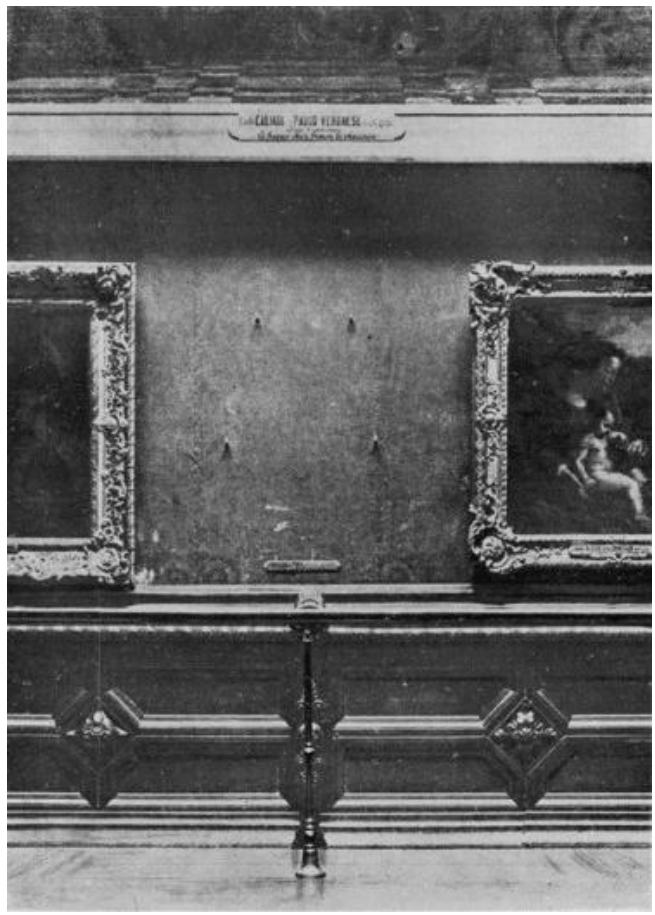


...mostrando o destaque dado para a pintura até então. Estava entre as outras, diferente da visão que temos do quadro hoje, centralizado em uma das grandes salas do museu, dizendo ao público venham me rodear.

Sem tirar a força da obra de Da Vinci, vemos os movimentos do museu, em consonância aos acontecimentos, como o roubo do quadro, concretizando a formulação de um mito e de um rito. O quadro chegou a viajar pelo mundo algumas vezes, sendo apresentado nos Estados Unidos, em 1963 e no Japão, em 1974. Nesta última saída do território francês, um visitante do museu atacou o quadro com um spray de tinta vermelha, alegando que o ato era uma reivindicação pela falta de acesso no museu para pessoas deficientes. Em 2009, o quadro foi novamente atacado por uma russa, que arremessou uma caneca no vidro, depois de perder o controle. Foi noticiado que o ataque aconteceu após ter seu pedido de cidadania francesa rejeitado. O quadro já havia sido alvo de uma pedra jogada por um boliviano em 1956, mas em nenhum dos casos houve dano à Monalisa ${ }^{26}$. Aliás, poderíamos pensar o contrário. $\mathrm{O}$ mito se erige através dos roubos e investidas. Vira alvo como forma de ataque à cultura ocidental, a falta de atenção às minorias ou a rejeição da participação da comunidade europeia.

${ }^{26}$ www.leparisien.fr/espace-premium/culture-loisirs/attaques-au-marteau-a-l-acide-a-la-tasse-de-the-09-02-2013-2552819.php 


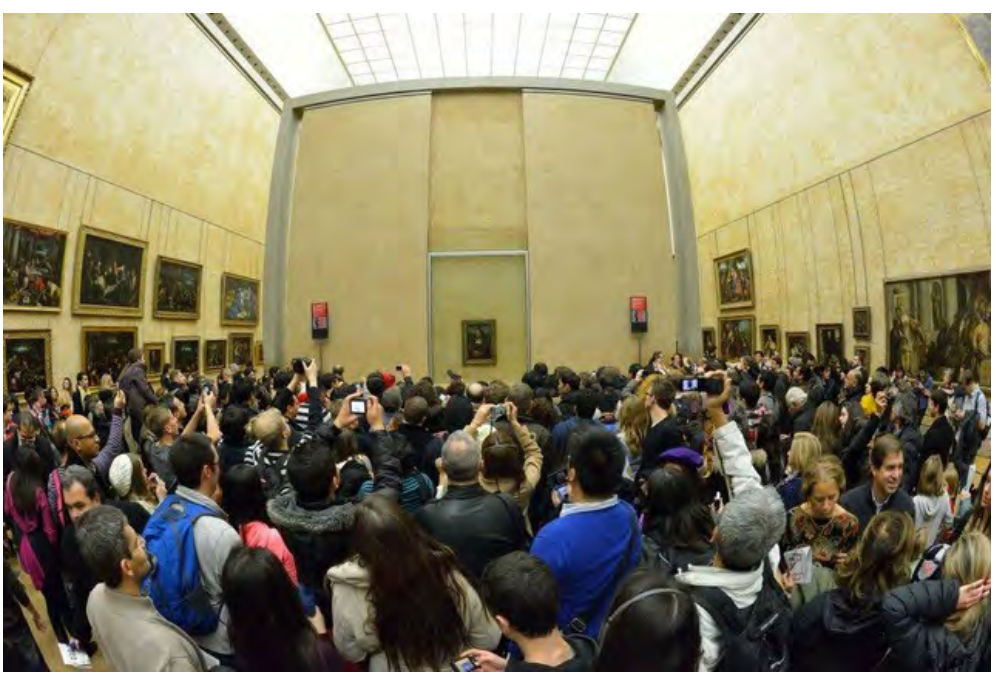




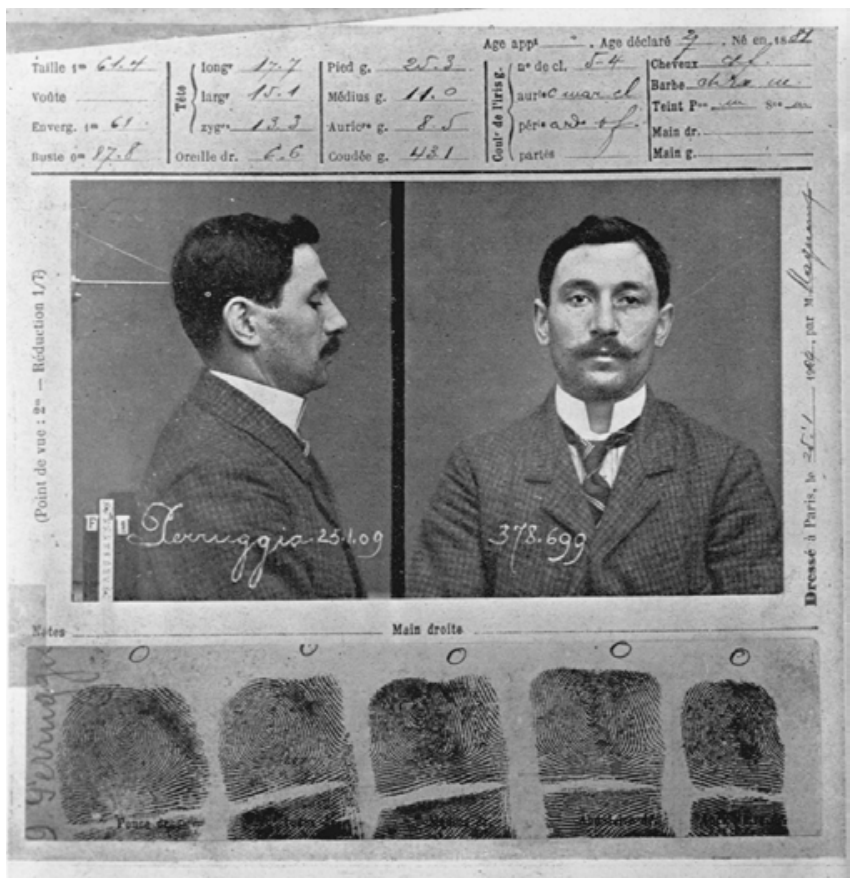




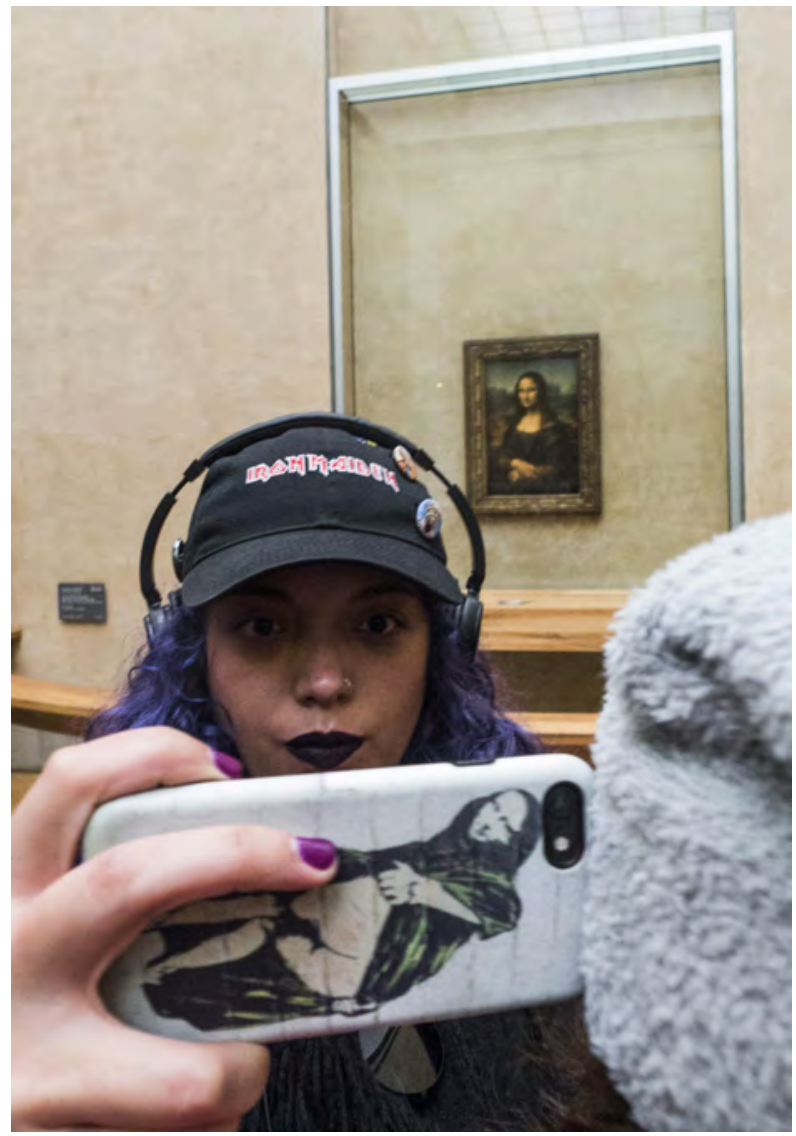


branco de sol

diário revisitado 


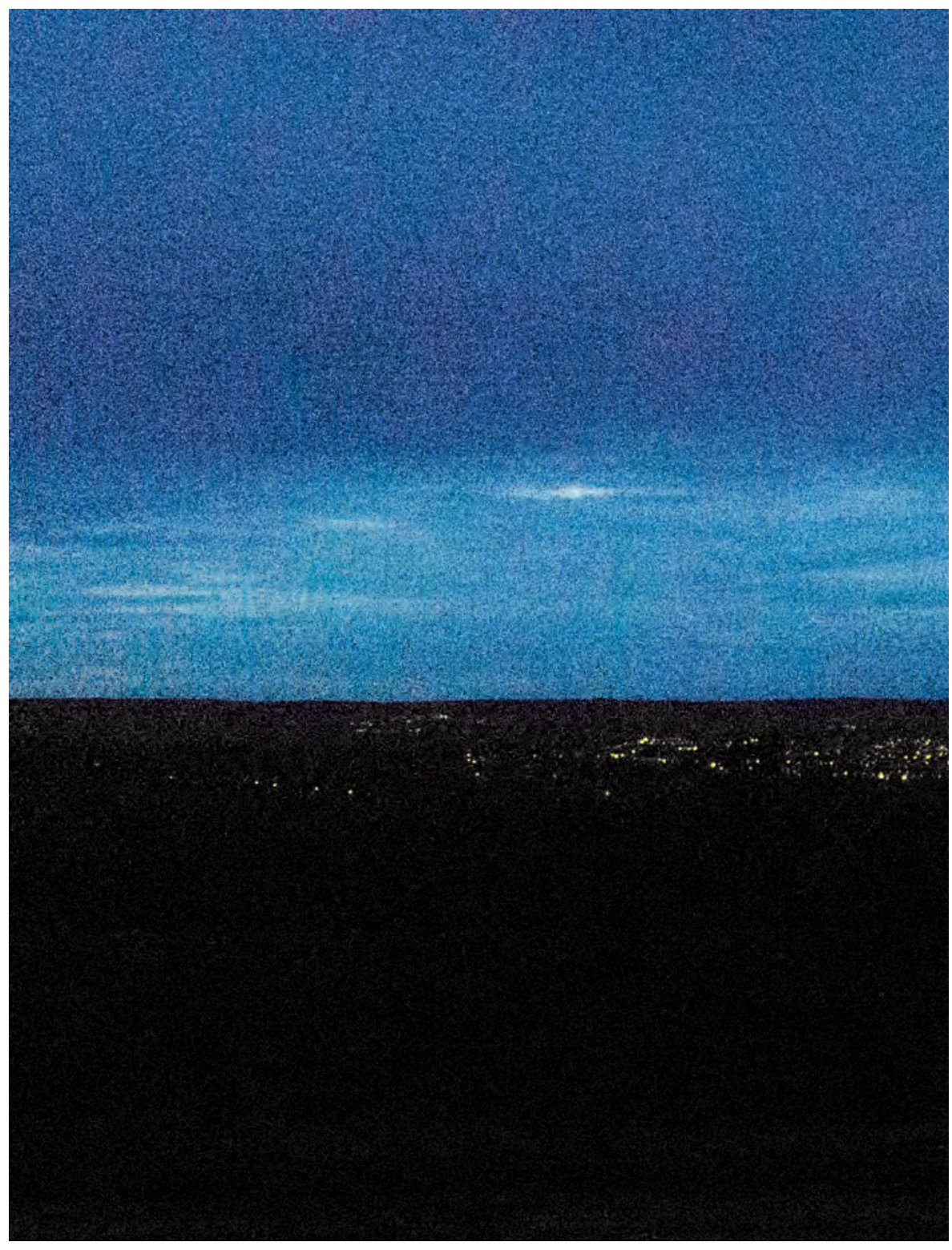




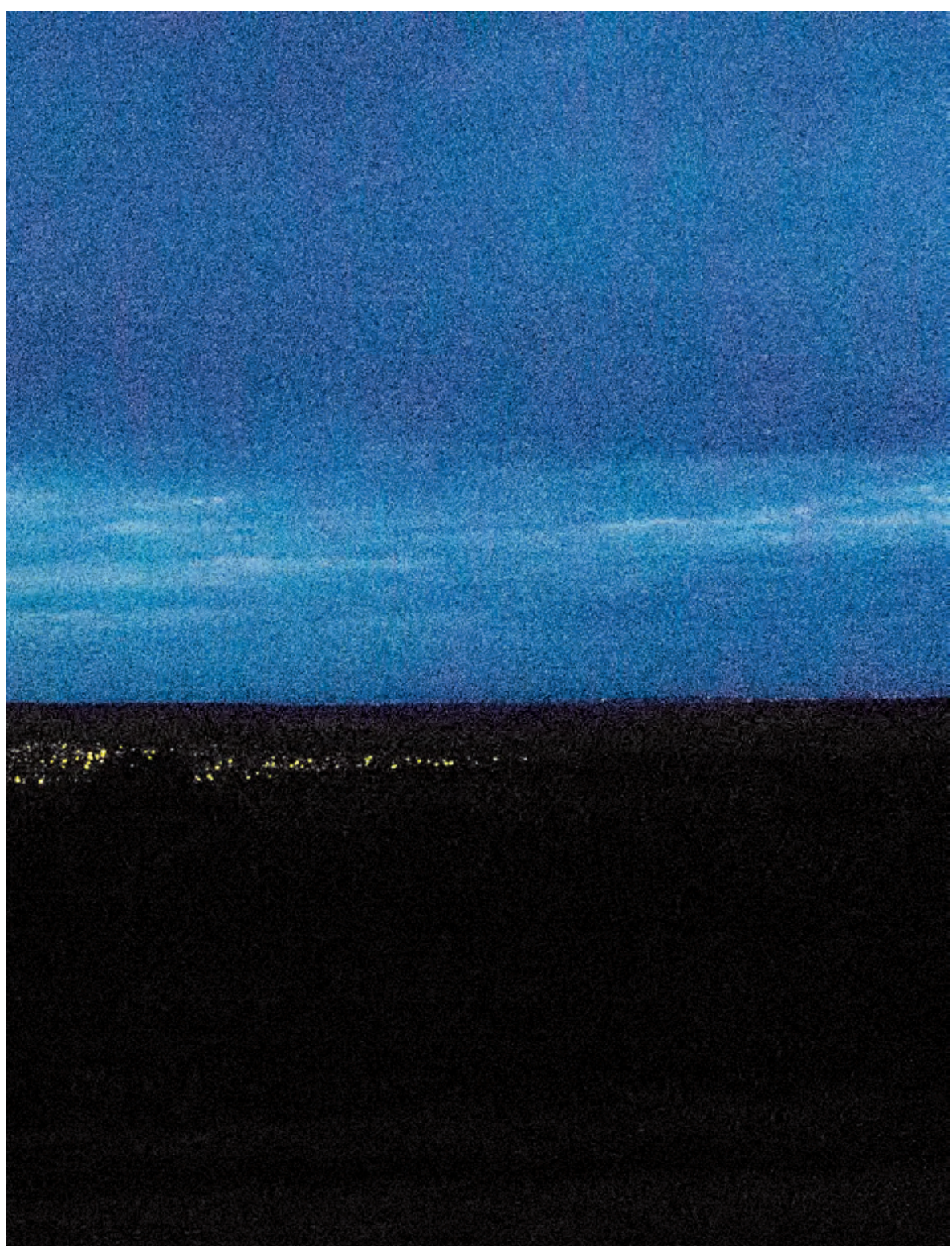


De tarde, arrumando as malas para Goiânia, a dúvida de quais câmeras pôr na mala. A máquina digital pequena, amadora, era a única certeza além do celular. A Canon analógica com uma lente normal e outra tele-objetiva já fazia parte das minhas viagens há anos. Precisava enrolar em bobinas os negativos de cinema.

Em 2013 recebi uma doação de aproximadamente uma dúzia de latas de negativo de cinema, todos vencidos ou prestes a vencer. Se bem acondicionados, suas ASAs pouco iam mudar. Tenho utilizado esses rolos desde então nesse processo de me trancar no quarto, à noite, luzes apagadas, cheio de pequenas bobinas fotográficas e durex ao meu redor e, debaixo dos cobertores, abrir as latas e transpor o negativo delas para as bobinas. No cinema, cada uma dessas latas, com 120 metros de negativo $35 \mathrm{~mm}$, fazem em média quatro minutos e meio de filmagem. Passando para a fotografia, estas latas podem alimentar dezenas de bobinas, me possibilitando fotografar em película no momento em que ela vem ficando cada vez mais rara e luxuosa. Quando comecei a fotografar com os negativos de cinema, conhecia apenas um laboratório no Rio de Janeiro, na Rua do Russel, que fazia este processo sem objeções. Isso porque era um laboratório profissional que revelava manualmente cada película. Esses negativos de cinema trazem uma camada antihalo, é uma superfície escura que suja o banho de revelação. 


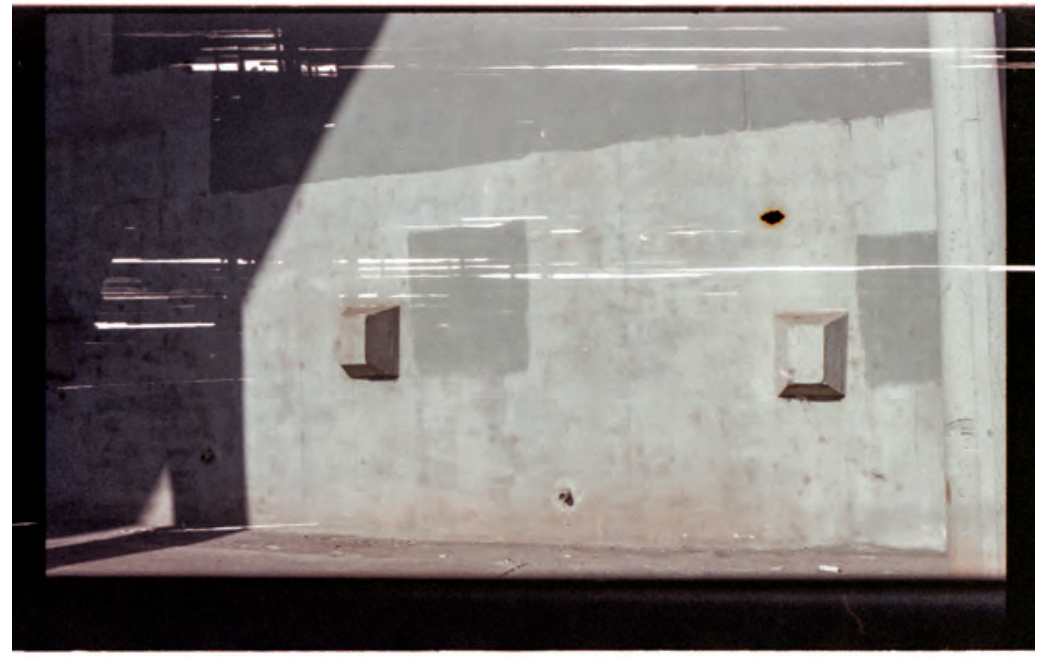


Quando o laboratório não consegue tirá-lo por inteiro, ficam seus rastros brancos na imagem positiva, sujando o banho dos próximos rolos.

Hoje conheço apenas um laboratorista aqui de São Paulo que faz este processo. Caso ele ache que não é lucrativo ou simplesmente se desinteresse em fazer essa revelação específica, provavelmente terei que parar de fotografar com as películas ou então revelá-las no processo preto e branco, apesar de serem coloridas.

Em casa não tinha mais nenhuma bobina, era preciso pegar em algum laboratório aberto no dia 26 de dezembro. Caminhamos pelo centro de São Paulo, eu e a Nina, cansados da viagem de volta do Rio de Janeiro na madrugada. Pela Xavier de Toledo, Crispiniano, 7 de Abril, Barão de Itapetininga. Nada. Antes do natal descartamos todas, disseram no Foto Ferrara. No final da procura a Nina ligou para um amigo, ele tinha dez bobinas sobrando, combinamos de buscar depois do almoço. Voltamos para casa com bateria para o fotômetro da câmera, há meses parada, e caímos num sono antes de manejar a mala do Rio para Goiânia e Chapada dos Veadeiros. Tinha especial vontade de levar a câmera porque boa parte das viagens que faço são para visitar minha família no Rio de Janeiro de ônibus e, mesmo de dia, a combinação das janelas do ônibus cheias de insulfilm com as baixas ASAs dos negativos de cinema, acaba impossibilitando as imagens que me interessam ser criadas. 


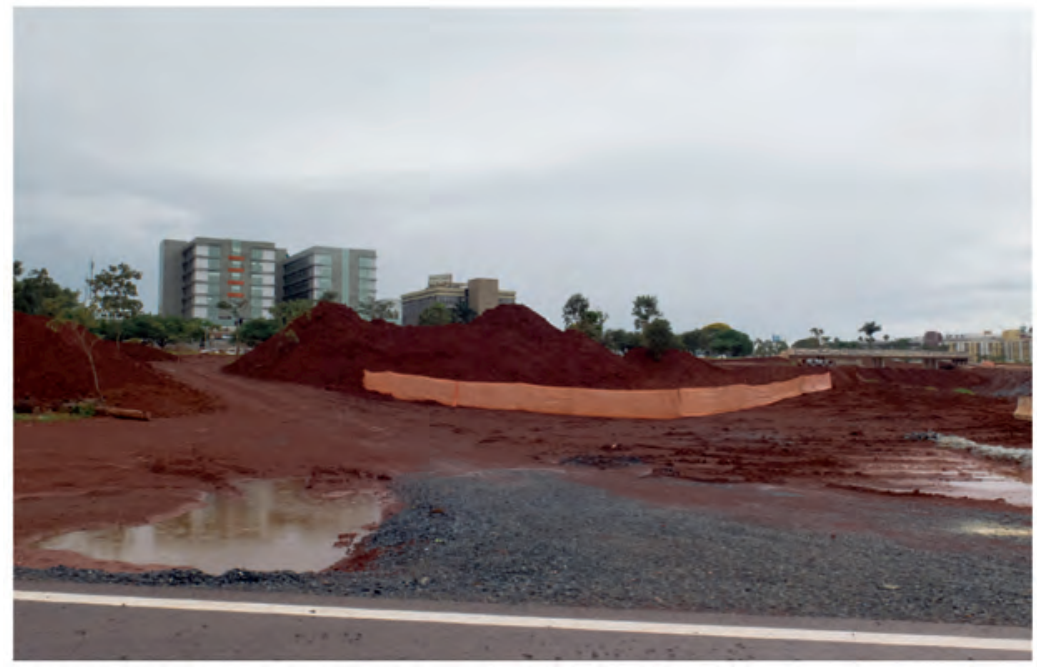




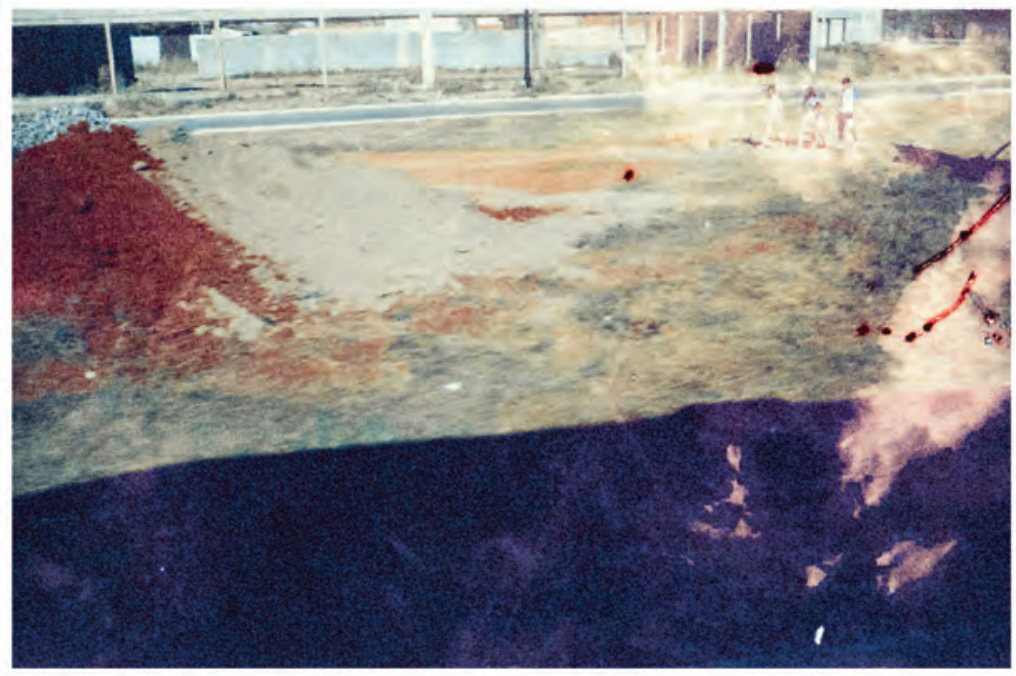




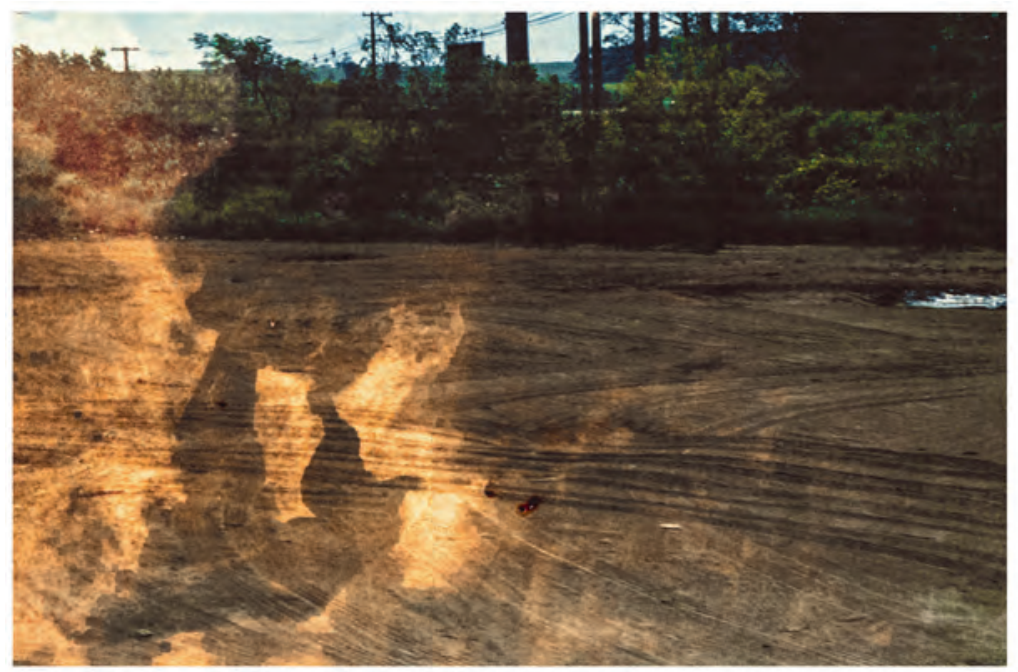




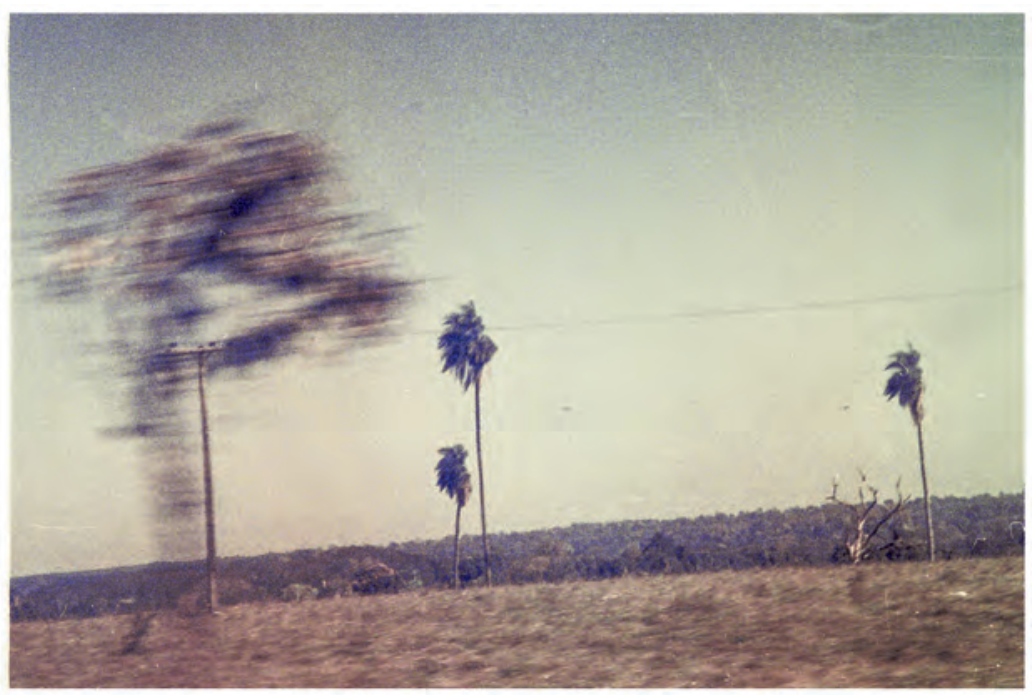




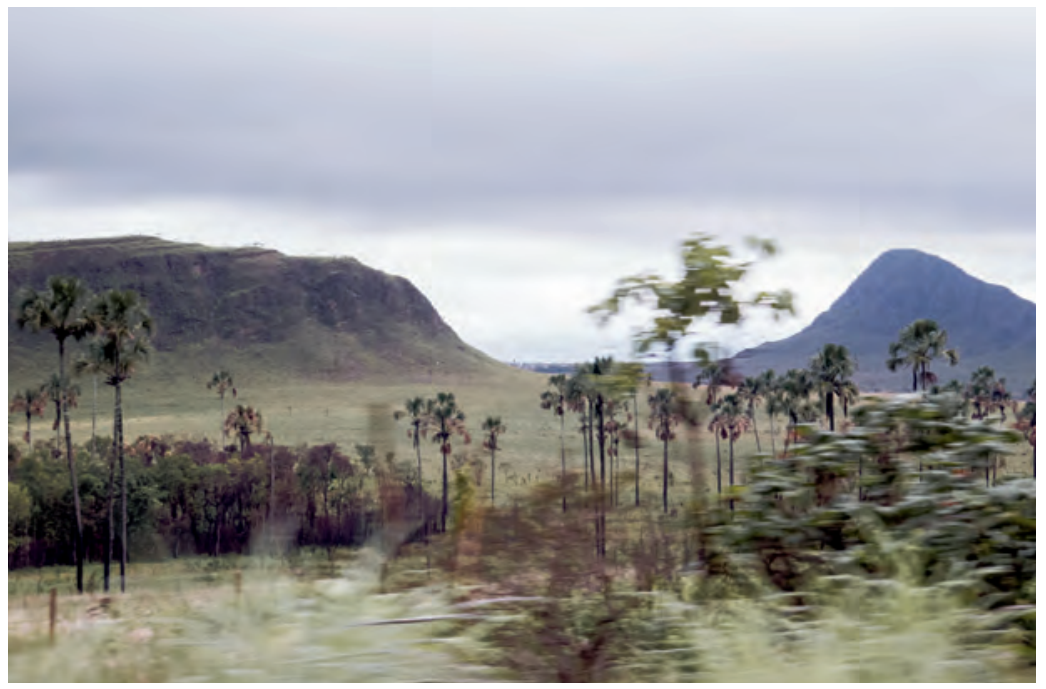




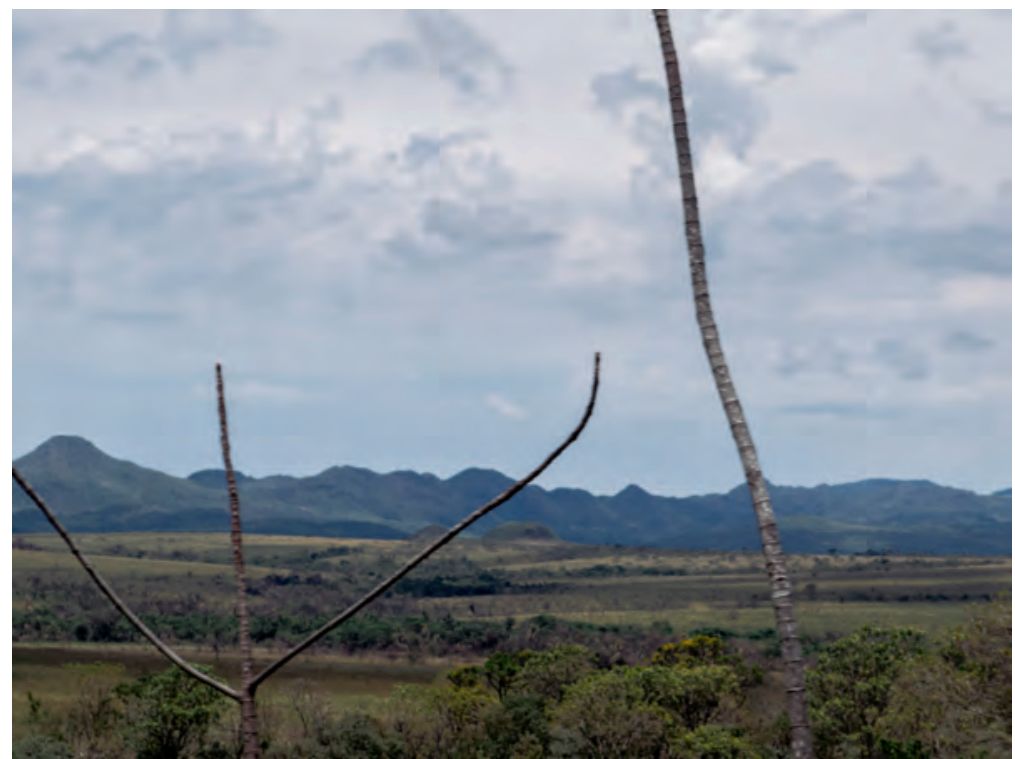


A viagem em agosto de 2015 para Brasília é um exemplo disso. Fomos e voltamos de ônibus, trinta e duas horas no total, e quase todas as fotos tiradas da estrada ficaram tremidas ou subexpostas pelo filtro-janela que obriga a baixar a velocidade da câmera. Agora, de carro, não haveria este problema.

Outro porquê da vontade de levar o equipamento analógico era uma fotografia da Nina de 2014 no Cerrado com essa mesma câmera e negativo. Levá-lo de volta para o centro do Brasil seria como criar fotos irmãs daquela.

Menos pela preguiça do que por um movimento de descrença na feitura de algumas imagens, a câmera, a Canon AE-1, a lente $50 \mathrm{~mm}$ e a $70-200 \mathrm{~mm}$ ficaram em São Paulo. A mala ficaria mais leve, não gastaria o dinheiro da revelação nem os dias escaneando as películas. O Cerrado seria digital, em baixa qualidade, bruto como o encontro da luz com os olhos desacostumados.

Minha única viagem apenas com câmeras digitais tinha sido para Portugal, no ano passado. Daquela vez não tive opção, iria passar duas semanas por lá só com uma mochila e dormindo ao relento. Toda a discussão, mantida ainda hoje, entre produção de imagem fotográfica analógica ou digital tem um caráter conservador ou econômico. Pouco se discute o interesse na produção de cada 
imagem em sua especificidade, na qual o produtor compreende o que deseja criar, incorporando as contingências.

A câmera que frequentava minhas viagens se recolhe como descrença em um tipo de imagem, aquela que pesa e carrega seu peso, o cuidado da quantidade, que quase, contradizendo o antes dito, precisa de um porquê para ser feita. Estas reflexões acerca da materialidade dos processos fotográficos rondam minha produção. Não chego a conclusões, não me parece necessário atingi-las.

Existe alguma coisa de procurar, na composição de um objeto bidimensional, de superfície, um ângulo, à distância mais ou menos sentida, um cenário. Não um cenário para a ficção, mas para a imaginação. Uma inversão entre fotografar o que se tem desejo de fotografar, como Hervé Guibert reclama como pulsão do ato fotográfico em A imagem fantasma, e uma fotografia que propõe a constituição de paisagens, cenas, momentos, esquinas, quartos, amigos, para ali a imaginação viver os desejos ainda não ditos ou formulados. Como se fosse possível o sentido das imagens antes dos desejos. Penso no trabalho do casal Straub-Huillet, que transformam através do tempo de duração, a fotografia em cinema. O princípio do cinema, a imagem em movimento, a reprodução de vinte e quatro fotografias por segundo para causar o efeito de 
continuidade, ganha no trabalho deles uma outra visualidade: a duração dos planos inibe a lógica do instante, o que importa é a vivência dos seres e paisagens eleitas, ou antes, filmadas sem todo o controle pretendido por alguns caminhos da estética cinematográfica do corte, das múltiplas tomadas. $\mathrm{O}$ filme que dá a oportunidade do mundo, pessoas, arquitetura e natureza ressaltarem.

Tenho enorme interesse no trabalho do casal. Esta fotografia que tirei em 2016 se encontra com este fotograma do filme Trop tôp, trop tard, que vi no ano seguinte da foto. Algo da aparição das paisagens, do tempo, das esquinas, dos muros, livros, surge como referência, mas de maneira quase inversa. Eles, com a preocupação de não destacar as imagens de seus referentes, criam o caminho para fazer filmes com posicionamentos políticos. Do meu lado, caminho para pensar imagens que, sem serem regidas pelo discurso, não contenham em si uma representação de uma ausência, mas carreguem ou apontem para sua própria presença. Preciso refletir mais sobre isso. Tem essa frase do Godard, contundente e postulador, dividindo duas maneiras de pensar o encontro entre arte e política: "não é uma questão de se fazer filmes políticos, mas de se fazer filmes politicamente". Talvez aqui haja um encontro, ou eu gostaria que houvesse, para além das formas, no que tenho como referência do trabalho do casal. 


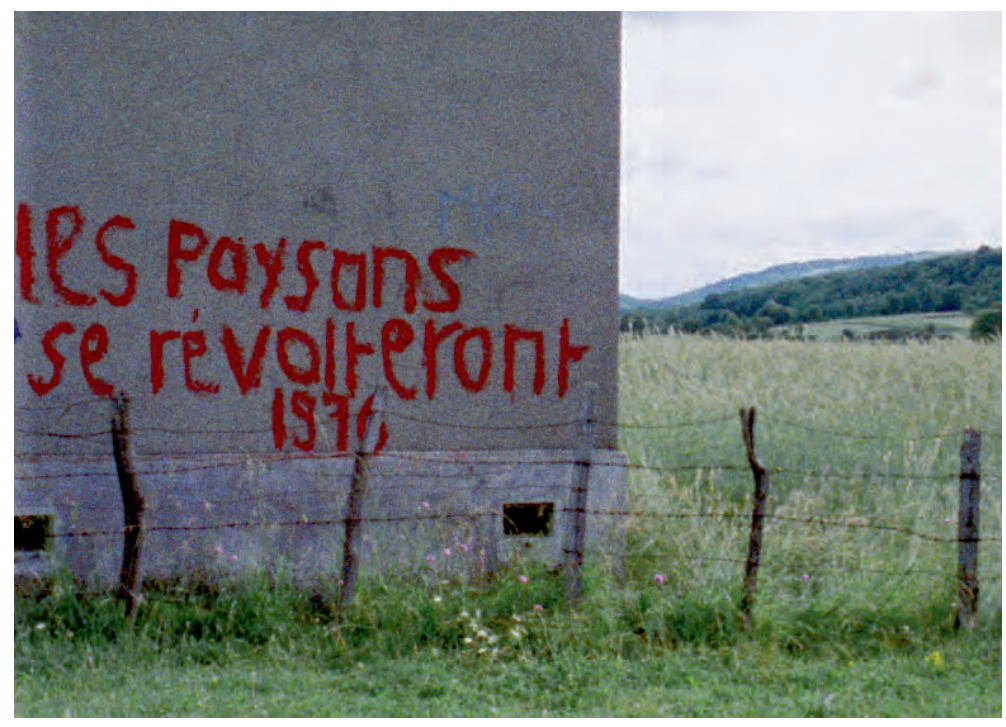




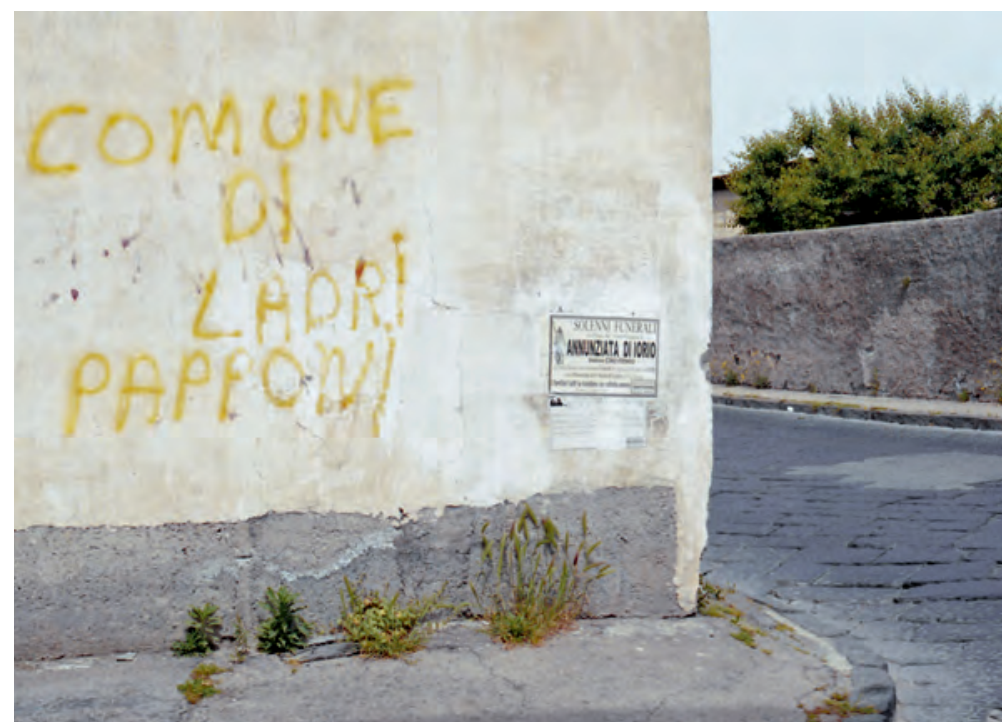


Soa nas imagens o envolvimento com a produção, e mais, soam os modos de produção das imagens, não temos uma equipe de trinta pessoas atrás da câmera no trabalho alienante que até o cinema de arte é capaz de realizar quando segue os modelos da indústria.

Ainda outro comentário anotado no verso do caderno sobre o trabalho dos Straub-Huillet: ...nascem como uma possibilidade de mundo, construir paisagens a serem vividas: não à toa a escolha de cidades pequenas e o campo para o cenário de diversos filmes. Uma construção de mundo paralelo, no caso deles trazendo encontros temporais de personagens contemporâneos e da antiguidade, textos literários na íntegra, o repertório intelectual encontrando a classe trabalhadora das fábricas e camponeses. A união de mundos numa imagem com potência de vida. Filmes propositivos de mudança.

Vejo o ensaio fotográfico do Eric Baudelaire, Imagined States, sem a identificação dos lugares e pessoas fotografadas porque estes se tornavam um novo no mundo. A noção de ficção é latente no trabalho de Baudelaire, é possível aventar , mas só aventar, uma pré encenação, um arranjo dos corpos e cenários. Vendo as imagens do trabalho, disponíveis no site do artista, caminhamos para o campo das especulações quando procuramos compreender como estas imagens foram produzidas: talvez o mundo tenha se 
apresentado assim e o trabalho fotográfico, o posicionamento da câmera e a espera pela iluminação desejada tenham construído este Estado Imaginado. Assim, classificá-lo como ficção é diminuir a experiência e olhar fotográfico do que produz imagens. A divisão ficção versus documento me parece tender ao fim. Se resgatadas entrevistas ou procurado o artista para desvendar a questão, o trabalho perderia parte de sua força, não somente porque a dúvida preserva o trabalho, mas porque haveria uma parte discursiva, do texto, da fala, que seria somada à produção primeira. Penso se a crítica ou o comentário de produções deva ser visto como uma nova perspectiva sobre o objeto, um novo curso para a experiência, ou uma nova conformação do objeto em si.

Me veio à cabeça o dia em que conheci o trabalho do fotógrafo italiano Luigi Ghirri, e tive certeza de que tudo aquilo presente nas imagens era orquestrado pela fala, combinado entre o fotógrafo e seus personagens. Hoje entendo que não, a orquestra foi feita pelo olhar e pelo tempo.

a fotografia da espera

Queria ter mais tempo nessas pequenas cidades em que passamos. Olhando para o tempo, não me parece à toa ter virado fotógrafo. Desde meus cinco anos, venho fazendo a viagem Rio-São Paulo, 


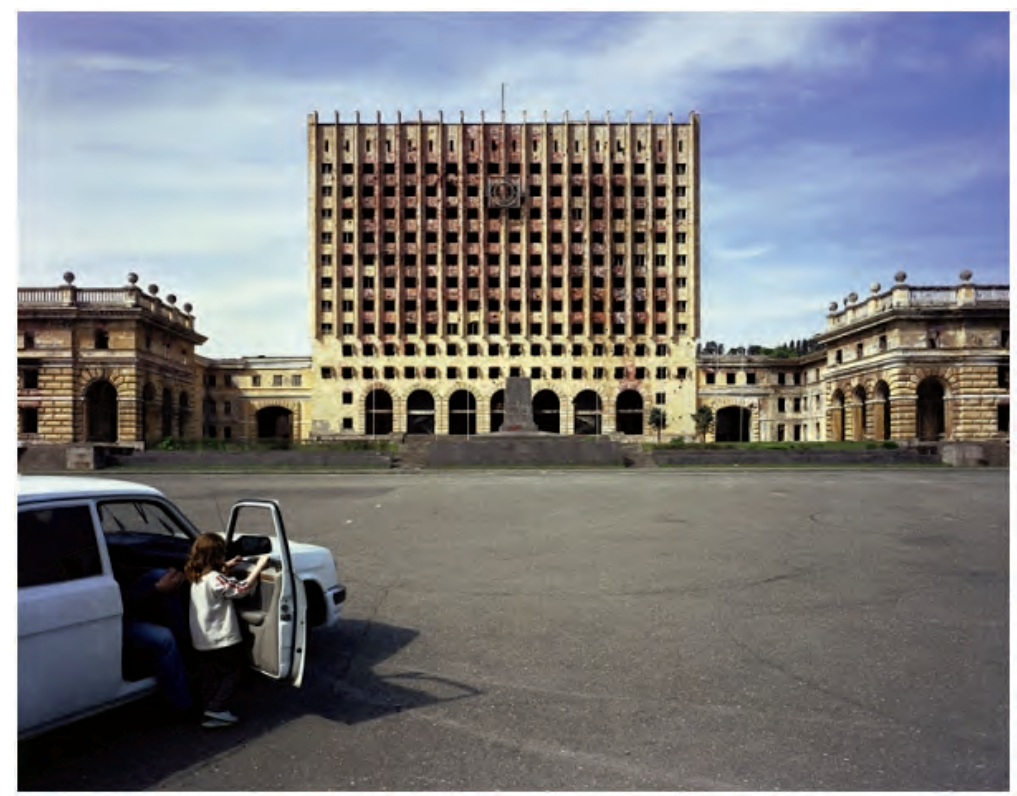


antes no banco de trás do carro dos meus pais, deitado enquanto acompanhava os fios elétricos dançando. Começava a olhar a paisagem e dizia pra minha mãe no banco da frente estou com dor de cabeça. Ela me respondia olha para os morros e não para as coisas que passam na beira da estrada. Desde essa época, tinha o hábito de piscar os olhos quando um objeto estava inteiro no enquadramento da janela. Um comércio, um carro, um grupo de pessoas. Hoje me prometo, a cada vez que pego a Dutra, rodovia que liga São Paulo e Rio, que um dia vou fazer essa viagem, que sem pausas é feita em cinco horas, por um, dois, três meses, parando em cada uma das cidades das quais apenas reconheço a borda.

Mal saio para fotografar em São Paulo. Às vezes, pra descansar, dou uma volta pelo bairro, Luz-Bom Retiro, com a câmera no bolso. Volto com meia dúzia de fotos, mal gosto delas. Entendi que andar e fotografar tinha se tornado uma prática estranha, inversa ao ritmo da minha vida. É como se eu estivesse procurando algo inexistente. A prática formadora da fotografia moderna, espécie de amor à cidade, é a constituição de uma imagem a ser propagada, um laço entre arte, urbanismo e vida comum. E assim, diversos fotógrafos construíram seus trabalhos, com beleza inigualável. Mas é a beleza que procuro? Fazer existir uma imagem no mundo, e não um texto, deve ter qualquer coisa 
de incompreensível, ou se compreendido, difícil de traduzir, de trazer para o campo das palavras.

Desde então, coloquei para mim que minha admiração ao trabalho de alguns fotógrafos, como o Luigi Ghirri já citado, está no tempo sentido em suas fotos. O corpo para. Ao invés do fotógrafo ser aquele que ronda, ele consolida seu lugar e, parado, os outros entram em seu campo de visão. Tem alguma semelhança com a rotação dos planetas onde um entra no raio eclipse do outro a depender da perspectiva que se tem, com o sol, que também continua participando dessa pequena foto: mas o que interessa talvez são aqueles corpos que não entram em órbita. Parado se sente, se pensa. O pensamento não precisa de palavras. Contra as fotografias que já fiz, em especial as de viagem, desejo a lentidão, ideia inversa ao consumo contemporâneo das imagens.

Também a fotografia pode promover encontros entre cometas, planetas e asteróides que sua aparente debilidade, a bidimensionalidade e fixidez, passam de causa à consequência no e se...: a formulação mais potente que temos transformada em materialidade de um instante que só existiu na foto.

E não falo da lentidão dos equipamentos, o uso de câmeras de 


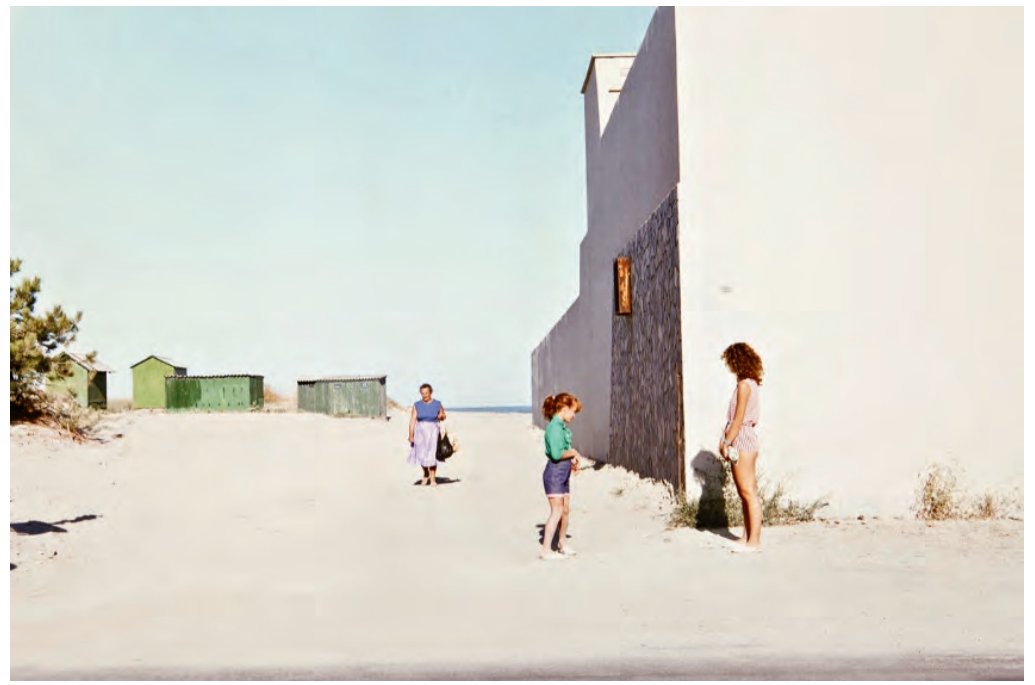


grande e médio formato, o tripé parrudo, a mala de lentes. A parafernalha fotográfica também constitui ritmo. A lentidão a que me refiro é do passo encurtado, da espera, ver os sinais abrirem e fecharem. Parar e olhar, ao invés de perseguir imagens. Compor espaços. Transformar o ato ativo do consumo em passivo, entrópico: se deixar consumir pela massa do corpo.

Esses dias anteriores à viagem, no Rio, minha mãe me vendo fotografar, novamente essa fotografia em movimento, parente do cinema, pergunta o que você está fotografando? Primeiro respondo nada em especial. Passados alguns minutos, mesmo me propondo a não ter temas estabelecidos, uma fotografia como prática de imaginação e vivência das formas, percebo algumas recorrências. Ali, no caminho entre as casas das minha avós, Copacabana-Jacarepaguá, cruzando o Rio da Zona Sul para a Oeste passando pela Norte, eram fotos em especial, olhava a maneira banal que convivemos com as estéticas do que não tem valor estético quando produzido.

O pretenso neutro, o mal acabado, feito de qualquer forma, à espera da reforma, o aparente descontexto com seu lugar de execução, sem meios para ser de outra maneira, colagem 
consciente ou inconsciente, quando adentram o mundo da imagem fotográfica, ou melhor, quando a fotografia é feita deste, construindo ou complementando colagens, acaba por coincidir com o funcionamento do ready-made. Faz-se olhar-pensar os espaços vividos em processo de trazer para discussão estética o que vivia no âmbito do sem valor ou desvalorizado. Expande-se a discussão estética desconsiderando a ideia de limite, convenção.

Na casa de um amigo, de janela virada para prédios, no centro de São Paulo, ele se lamenta pela vista. As costas da 9 de Julho, o céu perdia espaço. Digo a ele que a lateral descascada, branca, cinza, preta e mostarda, um paredão sólido de quase trinta andares, parecia uma pintura abstrata feita pelo tempo e pelos defeitos de infiltração do edifício.

A reclamação ou apontamento de Delacroix sobre a fotografia frente à pintura era sua dimensão de recorte contra a inteireza, $o$ sentido da manufatura. $\mathrm{O}$ recorte do mecânico versus a essência do manual. Mecânico e manual, palavras antes opostas e agora misturadas frente ao automático e digital.

A fotografia pensada por Delacroix não carrega inteireza, não só pela noção do enquadramento da lente e janela do negativo, mas por seu caráter de captura de uma existência material, algo que 
se fragmenta e se consolida, firma um tempo passado em imagem de fácil referencialidade.

Mas essa imagem formada não é um presente no mundo? Um antes invisível, ou melhor, inexistente, e agora uma construção tão só da fotografia? As críticas formadoras da disciplina Fotografia direcionaram reflexões para o medium e não aos seus utilizadores. É difícil e desnecessário compreender os limites e sentidos imanentes à fotografia. Devemos caminhar na observação de seus usos e dos desejos dos corpos atrás das câmeras, dos computadores (parte irredutível da fotografia contemporânea) e dos que a observam.

Desde a primeira vez que li o texto Platão e o simulacro, no livro Lógica do sentido, me deparei com uma provocação fundadora em consonância de sentido com imagens fotográficas que me interessava produzir. Neste pequeno ensaio, vemos a noção de simulacro: o que é falso e não carrega a ideia, a essência do que está representando, em oposição à cópia, imitação ou mimesis, sendo revertida e positivada. Contra a arte que caberia na República, Deleuze demanda a participação dos simulacros, que estes se insiram no caos contemporâneo e sejam uma visão anárquica que não se produza com sentido de verdade e sim como potência do falso. 
Só o que se parece difere, só o que diferente se parece, introduz Deleuze. A analogia entre o simulacro e a fotografia é clara e especular. Ele continua: “o simulacro não é uma cópia degradada, ele encerra uma potência positiva que nega tanto o original como a cópia, tanto o modelo como a reprodução". Tirar o peso de representação, de cópia da fotografia é o caminho possível de compreendê-la como um novo no mundo, dar seu estatuto de vivência, ao invés de uma materialidade que existe apenas como representação de uma ausência, uma presença em diálogo com as demais presenças, inclusa aquela, às vezes, de fácil referencialidade.

A presença contemporânea das imagens. O tempo transforma as dicotomias. Como fazer a oposição real versus virtual, hoje, quando andando pela rua se vê anúncios de aplicativos recém lançados, conversas no ponto de ônibus sobre conversas online, pessoas e espaços que regem o país e somente vistos via tela?

No caminho de volta da Chapada dos Veadeiros para Goiânia, peço aos amigos para passarmos, nem que seja para um café e uma volta de carro, por Brasília. O desvio era pequeno, a rodovia passava pelo limite entre a capital e suas cidades satélites. Eles toparam. Chegamos à tarde, com uma chuva rala, céu coberto. No carro, algumas conversas entrecortadas pelas paisagens e músicas pop do rádio. 
Há qualquer emoção perturbada em passar por Brasília, ver um dos maiores, se não o maior projeto urbanístico e arquitetônico do modernismo, a construção de uma capital. A construção de uma ideia. E uma ideia que consegue carregar em suas formas, disposições e materiais, a palavra ideia. E tudo fica com cara de passado. Como nos filmes futuristas onde podemos datar o desejo de futuro de cada época. Em Hollywood, 2001 uma odisseia no espaço, o futuro dos anos 60, O dorminhoco, o futuro dos anos 70, Blade Runner, dos anos 80, Matrix dos anos 90, Minority Report dos anos 2000, Black Mirror nos anos 2010. Brasília era uma espécie de chute de futuro pensando seu presente. Sua construção, prédios modernistas, espaçosos, com áreas livres incomensuráveis na ausência de portões, e seus construtores, os candangos, vivendo em casas feitas com o saco do cimento utilizado no sonho moderno.

Lorenzo Mammì, no ensaio A construção da sombra, relembra uma fotografia feita por Gautherot à época da edificação de Brasília. Em sensível analogia, Mammì aponta para as sombras das fotografias, às vezes sombra do próprio fotógrafo. $\mathrm{O}$ chão de Brasília é uma sombra enorme, tão preta que parece não haver nada ali. E assim se funda a cidade que, na falta de comparativos, nasce do vazio. 


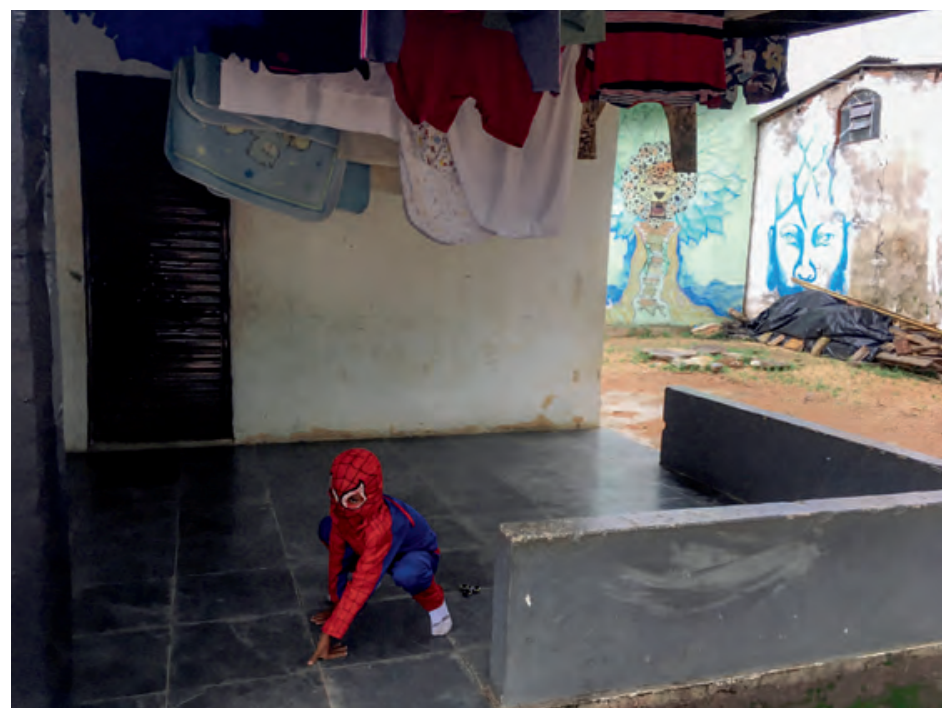


A televisão repete insistentemente, sem grandes variações de ângulo, a entrada do Palácio do Planalto feita de vidro não transparente.

Os problemas da representação aqui se encontram tanto em imagem quanto no regime democrático, a distância entre original e cópia permite o desencontro forjado em encenação. $\mathrm{O}$ teatro da política torna-se mais especular conforme as câmeras são ligadas. Como numa sala de espelhos ouvindo centenas de rostos, determinados apenas pelo jogo das luzes coloridas, repetindo os mesmos discursos. Alguém já viu o presidente do país ao vivo?

O QUE SE TORNAM FOTOS DE VIAGEM?

A idéia de reconhecimento é posta na experiência do viajante sob óticas diversas: Na cartografia, de guerra ou exploração, usa-se reconhecimento de terra, pressupondo no re, o parentesco desta com as já conhecidas. Assim, conhecer um novo território é amestrá-lo em égides de segurança, busca de semelhança, identificação com o já conhecido para obter estratégias de circunscrição deste novo-velho espaço. Reconhecer é então pressupor o desconhecimento de um novo, ou melhor, é restringir a ideia de novo nos territórios do já conhecido, das palavras já detidas. 


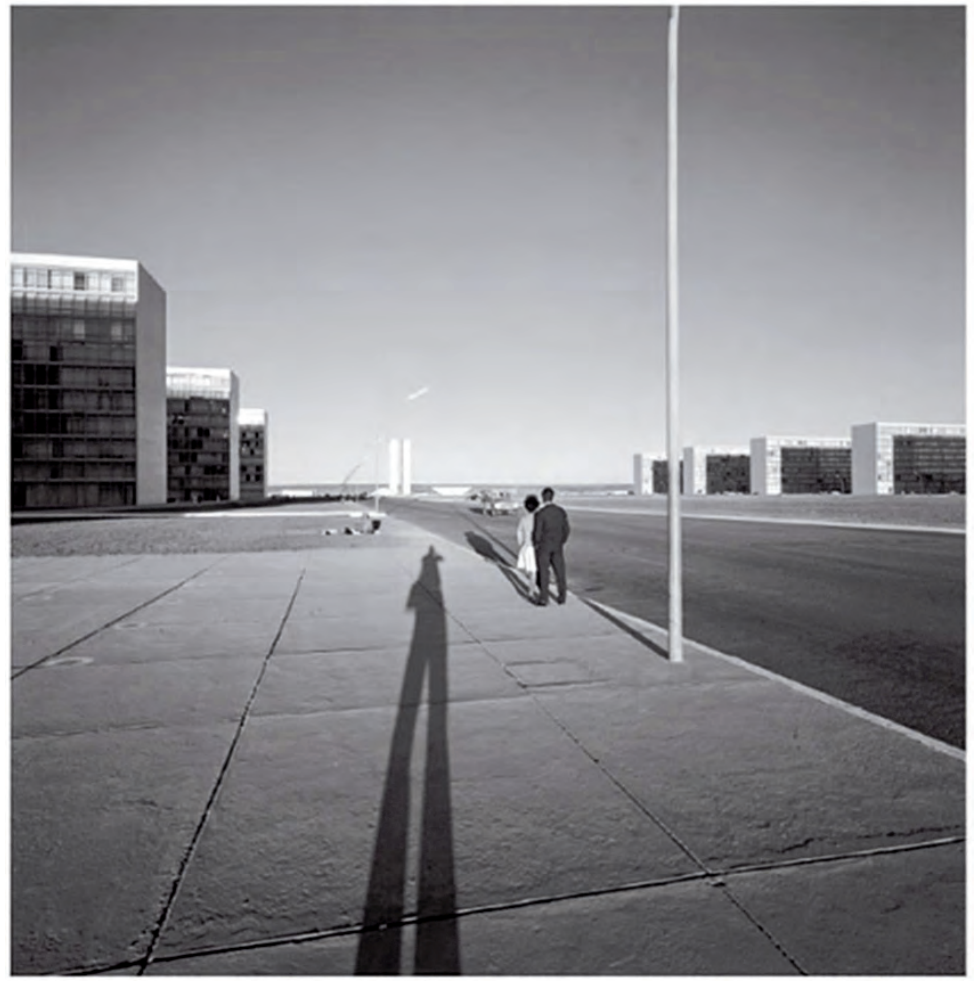


Este reconhecimento do viajante torna-se um movimento interior dito exterior. Diz sobre os novos locais experienciados como se fossem correlatos aos antes vividos. O reconhecimento assim é o conhecimento por comparação. Existe conhecimento sem comparação?

Para outro tipo de viajante, o reconhecimento é dar-se conta do seu mundo, do seu ser, olhando outras terras, outros hábitos e pessoas. Reconhece então sua existência.

Este rio é enorme

A chuva é torrencial

O calor daqui...

Você viu que estranho...

A fotografia torna-se o meio antropológico por sua transparência, corta as barreiras entre as palavras que criam graus de qualidade entre o novo espaço a ser conhecido e o viajante cheio de experiências já concebidas.

Escrita da luz, escrita do sol, a imagem fotográfica não mente, vêm dizendo muitos homens ao longo dos últimos cento e oitenta anos, a união entre os produtores de imagem e seus chefes, entre o aparelho e o programador, os meios de comunicação. 


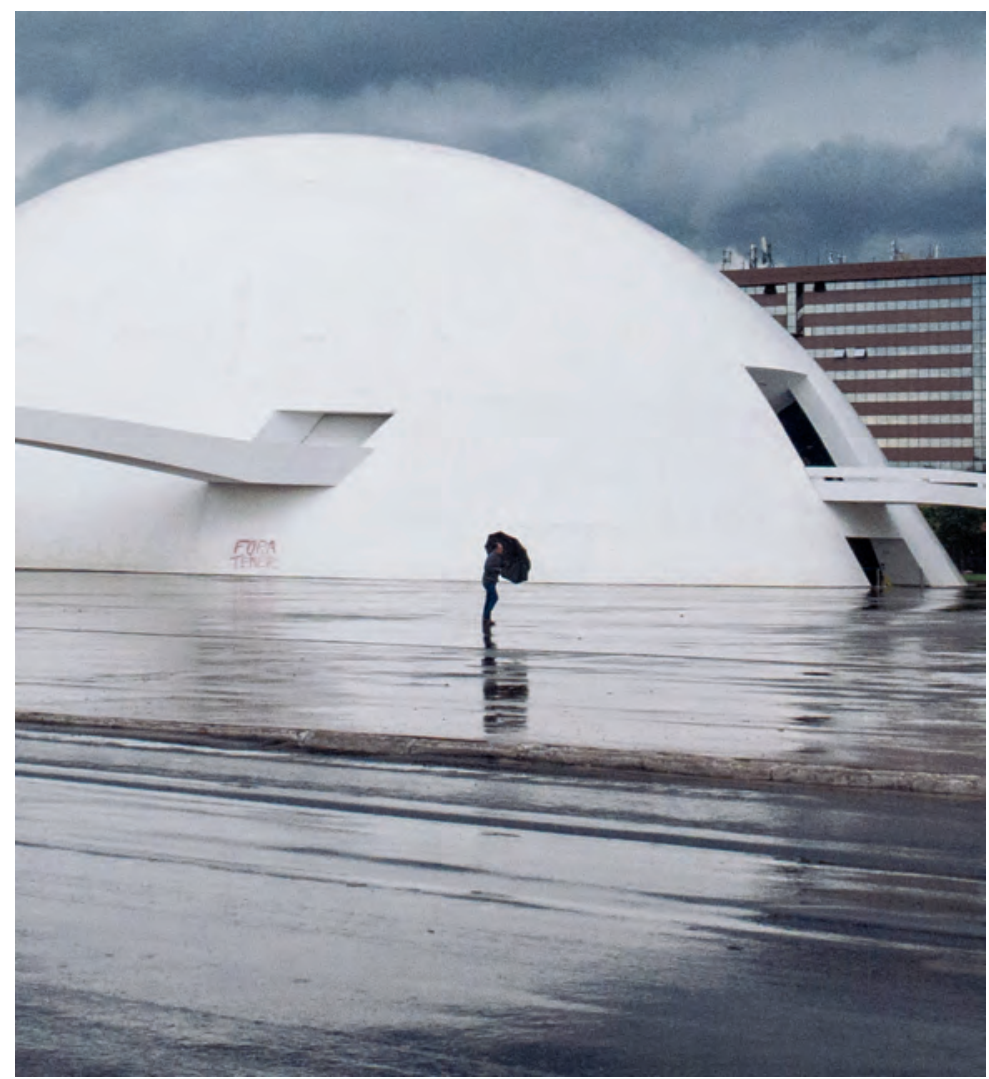

O homem preso e envolto na imagem que reflete e constrói também a terra. 
...uma foto do Yann Gross, fotógrafo suíço que subiu do Mato Grosso até o Peru, cruzando a Amazônia tentando se desvincular da fotografia do exótico, aquela, como ele mesmo coloca, que exalta pela distância e é incapaz de perceber o que realmente acontece no lugar. Seu trabalho se apresenta como livro, The Jungle Book: Contemporary stories of the Amazon and its fringe. A foto em questão não tem magnitude, é feita sob um leve azulado e enquadra um índio olhando para a lente, centralizado, corpo inteiro. Antes de chegar ao Brasil, Gross já havia realizado um trabalho fotográfico extenso em seu próprio país mas fugindo das principais cidades e, sobretudo, da ideia de um país rico e plácido no seio da cultura europeia. Dessa viagem interior entre Alpes com uma pequena motocicleta, podemos ter acesso à uma Suíça menos imaginada. Horizonville, uma das cidades visitadas e cujo nome se tornou título do livro de fotografias, se aproxima de muitos outras cidades do planeta por sua absorção desenfreada da cultura americana. A transmissão desta é, conforme sua expansão no século XX, um telefone sem fio. Se nos Estados Unidos ela tiver sentido, a milhares de quilômetros de lá, misturada pela maneira que a cultura se difunde e se cria...

E essa Suíça menos conhecida despertou em Gross o ímpeto de vivenciar sociedades que costumam ser pouco compreendidas, quando não subestimadas: os povos ameríndios e aqueles que já 


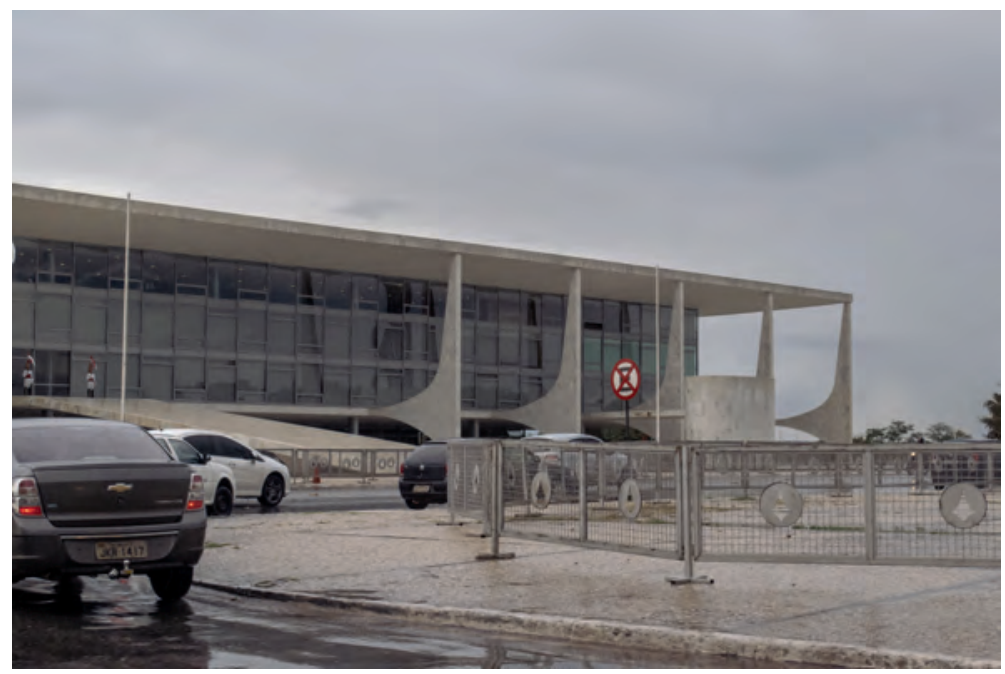


vivem o entre cosmologias. O que ligava suas duas experiências, além de criar trabalhos fotográficos, era perceber as influências da globalização nos mais recônditos cantos mundo. Pensando agora, seu trabalho era também uma espécie de reflexão fotográfica dos meios de comunicações. No livro, eu via a História da Fotografia ressaltar, o gênero Retrato sendo fotografado e a antropologia vertida ao fotógrafo e não mais ao fotografado.

Gross ali desejava conhecer outras culturas, mas a fotografia o alimentava a reconhecer pelas práticas do olhar que enquadrada, captura, fixa lugares e pessoas, e a construir imagens que se assemelhavam à sua observação da cultura que homogeniza e contradiz processos orgânicos.

Fugindo de certo exotismo, fazendo belas fotografias pela Amazônia, Gross atingiu outro ponto de sua crítica, a materialidade em si das fotografias exibia os gêneros consagrados desse medium que ignora as diferenças de cultura e representa díspares como pares.

Assim, sua fotografia carrega, como a materialidade das fotografias costuma carregar, a verdade de seu produtor. Neste caso, Yann Gross se colocou em viagem e não propôs assimilar sentidos próprios de cada lugar em seu trabalho. Como viajante, suas 
imagens são de uma só vez, a relação produzida por estes encontros. As cores frias e delicadas de suas fotos na Amazônia são a estética proposta, transformando o vermelho saturado das penas do cocar em um pálido composto cromático entre céu e terra. Como se em sua paleta cromática e enquadramento, Gross assumisse a distância entre ele e o índio fotografado, entre a fotografia e a pretensa representação do mundo.

Fotógrafos caçam, disse Flusser. Fotógrafos caçam, disse Bresson e Doisneau. Gross fotografa índios caçados pelo Estado brasileiro, fotografa diversos índios com o corte de cabelo do Neymar, camisa dez da seleção que os caça. A fotografia é e fotografa o telefone sem fio, é e fotografa a cobra mordendo seu rabo.

Tirar o re das palavras.

A analogia e a comparação costumam carregar cercas consigo. Comparar é um hábito e, vez por outra, procurar a diferença entre similares é expansivo. Proponho pensar fotografias como presentações, forma de distinguir, especialmente na contemporaneidade, onde o domínio das imagens faz-se necessário parar controlar e designar os dois movimentos de realidade: a imagem como um real, em pé de igualdade com o pretenso representado, 


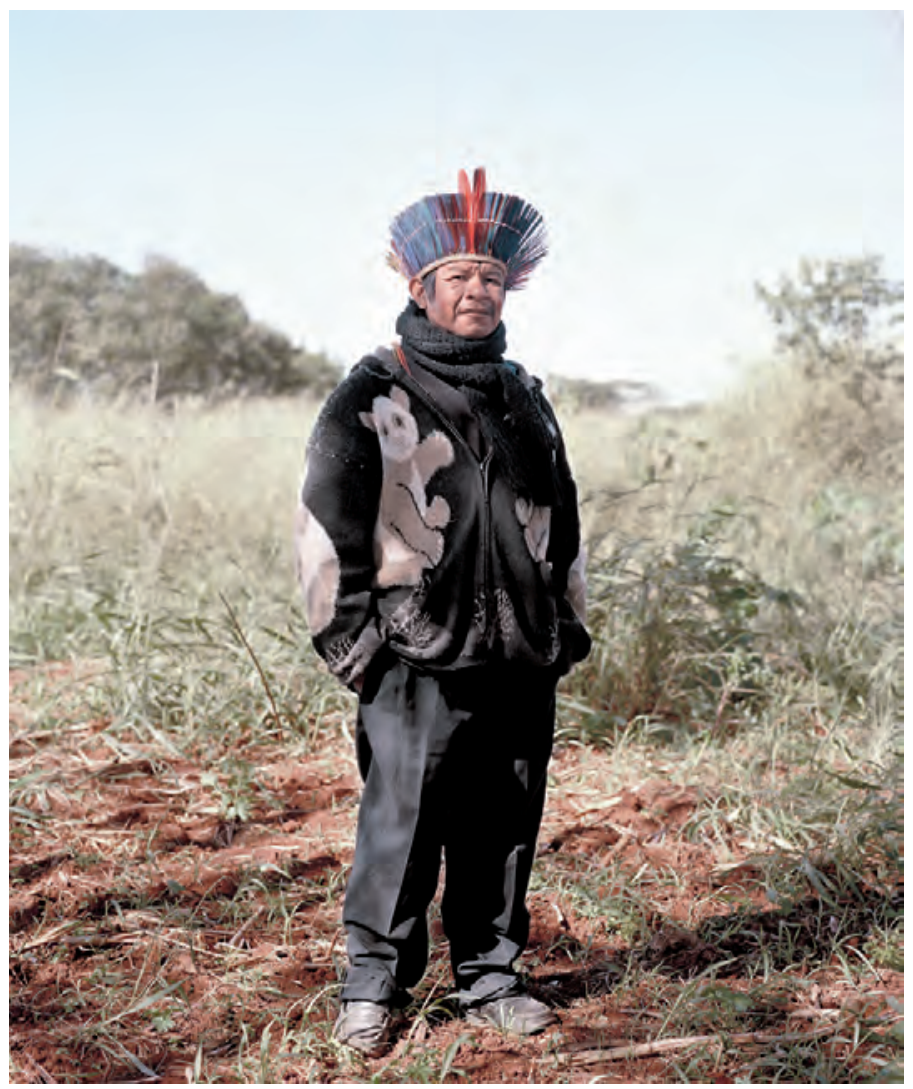




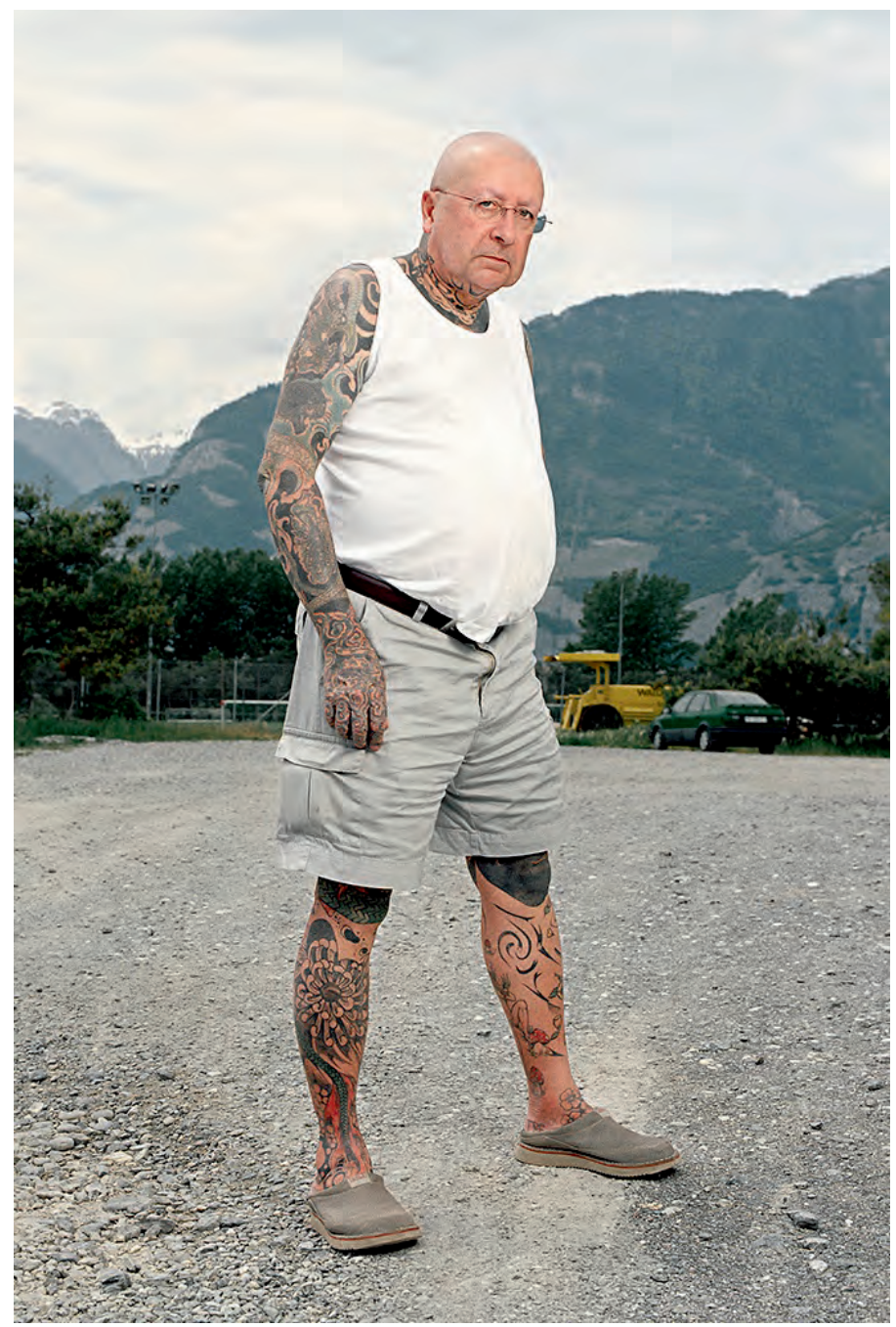


agora buscando as comparações e processos de construção das imagens, antes de uma visualidade transparente.

David Levi Strauss, em seu artigo Sob Controle, relembra célebres manipulações em fotografias na História da Política do século XX e além. Hitler, Stalin, Kim Jong-Un. Todos estes se valeram de montagens e apagamentos para governar os sentidos das imagens. O que torna o artigo especial, é a virada que Strauss faz para o controle da imagem do governo Barack Obama, no qual o acesso de fotógrafos tornou-se cada vez mais seleto, tendo sua imagem construída e veiculada por uma equipe oficial, interna. Strauss indaga a diferença entre as montagens dos ditadores e a imagem super produzida de Obama e tantos outros líderes, empresas, e demais participantes do mundão.

\section{A MATERIALIDADE DA IMAGEM FOTOGRÁFICA:}

E o enquadramento, como a palavra decreta, é a cela, é o fotógrafo enquadrado. A fotografia assim, o viajante, produz imagens enquadrando a si, o que lhe interessa e como se fez a relação deste com o desconhecido, o diferente. À frente dos objetos das fotografias está a fotografia em si, ela como uma carta de baralho equilibrada, que a depender do vento, cai para o lado do objeto ou para o do operador da câmera. 


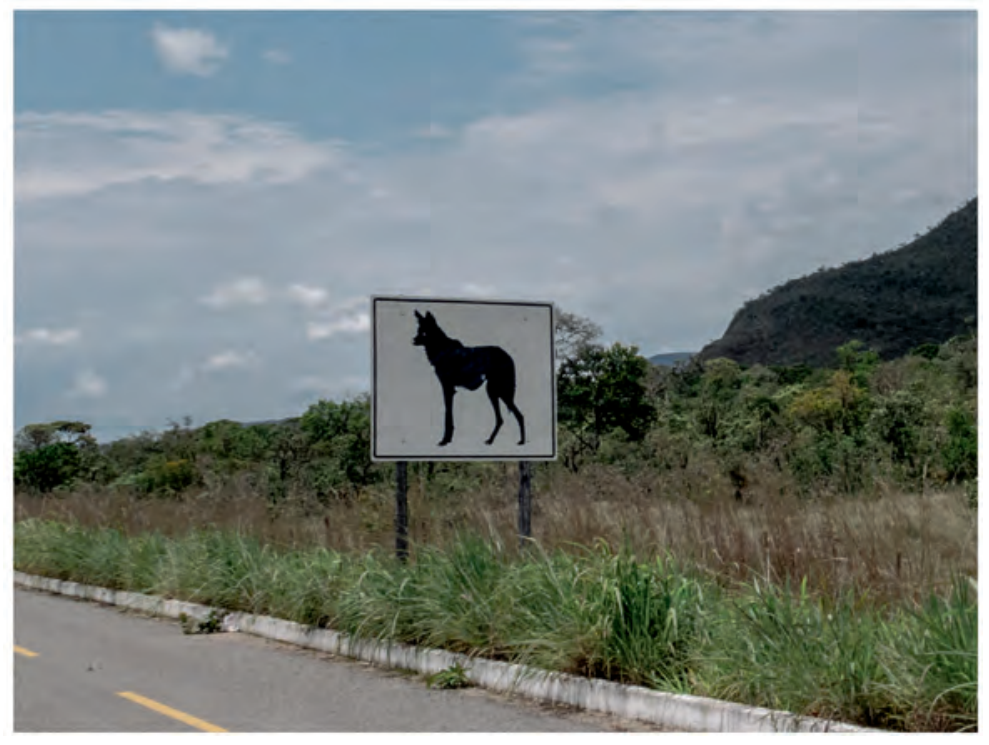


Banalizar a imagem técnica como meio, trazê-la como mero suporte e não construção e distância foi o desejo e sucesso da televisão na segunda metade do século XX. O principal conceito do Cinema Clássico é a imersão. A sala escura, o silêncio, a luz potente do projetor abrem caminho para uma narrativa sem menções de estrutura. O filme, uma janela para outra dimensão, bidimensional, com seus travellings sutis, atuação e iluminação pretensamente naturalista, criou a sintaxe da transparência, amorteceu e conectou os olhares.

Então se imagina a foto sem a presença de seu viajante e seu aparelho.

Traz a câmera aos olhos e entre você e o outro há um conjunto de lentes, um aparelho escuro protege seu rosto. $\mathrm{O}$ ato fotográfico é a antropologia do ativo, preocupado e desejoso de uma imagem. Fontcuberta, artista e teórico espanhol, calcula a quantidade de fotos colocadas na internet diariamente. Sua tentativa é mostrar como fotografias hoje são feitas pelo ato de se fazer, e não mais para serem vistas. As fotografias de viagem, guardadas ou esquecidas nas pastas do computador, criam a segurança, em seu instante de produção, de que aquilo é real. A prova fotográfica.

Por que vocês fotografam e filmam tanto? Ouvi de uma senhora, 
dentro da casa dela, acompanhando uma equipe de filmagem em um conjunto habitacional na periferia de São Paulo. Ela prosseguiu, e sua voz ecoou nos corredores do prédio, vocês vêm, filmam e a gente nunca mais vê esses filmes. Passam o dia aqui e depois nada acontece.

...e parte da ética da produção de imagens de um outro é dar acesso ao material, fazer ver sua circulação. O que aquela senhora esperava, por que a frustração em sua fala, como aquelas imagem poderiam fazer algo acontecer? Talvez haja paralelo com os programas dominicais da televisão aberta. Talvez seja uma relação que todos temos entre registrar e transformar. Talvez tenha faltado, como costuma faltar, uma relação que transforme a expectativa do que esse material poderia mudar no futuro em uma mudança no presente, trocar a ideia de que a transparência está no material registrado, para a transparência entre os que participam da imagem. A pensar.

No carro, a ausência substitui o tédio. Sentado no banco do carona, a paisagem. Com uma câmera constrói-se uma paisagem, pensa-se o tempo, seu comprimento. A fotografia no ato de deslocamento nada pode dizer sobre o que se passa. Talvez diga de uma montagem de imagem, mais em conexão com a colagem do que com os espaços percorridos. 
Nessa viagem estávamos em dois carros partindo dia 29 de dezembro de Goiânia para Chapada dos Veadeiros, Alto Paraíso e São Jorge. Apenas dois de nós dirigíamos, eu e o Rafael, um carro para cada. Sendo assim, eu não poderia tirar fotos durante o trajeto, pensar e construir essas paisagens para depois olhar e sentir as impressões fotográficas. Fiz então um pacto com a Nina, sentada no carona: iria dizendo a fotometragem e enquadramento, dizendo o que fotografar e ela, por já conhecer meu trabalho, iria mimetizar meu olhar, fotografar o que eu fotografaria. As fotos dessa viagem foram feitas no modo condicional, fotos parecidas com fotos. Talvez o interesse delas seja a relação entre mim e a Nina.

Imagens de tradução. Assim as traduções tornam-se originais pela perda inexorável das fotos que só se construíram em latência.

Me prometi não fazer mais viagens de carro dirigindo pela agonia de não fotografar. Em geral estas fotos são banais. Não são, dentro da maneira de se criar relações entre eu, a câmera, os espaços e as pessoas fotografadas, o que me move. Mas há qualquer coisa de jogo, de aprendizado. Essas imagens talvez sejam sempre imagens de fotografias jamais tiradas porque jamais se vive além daqueles segundos, em alta velocidade, não 
se coloca os pés no chão dos espaços construídos.

Na entrada do Parque Nacional da Chapada dos Veadeiros há uma placa de boas maneiras. Nela aparece: Retire apenas fotografias.

Tirar uma fotografia, fazer uma fotografia.

Os verbos dizem de duas correntes da fotografia, presentes desde os tempos de sua invenção. Apresentada em sincronia nas Academias de Belas Artes e Ciências, o registro e a criação iam designando os caminhos desta que, na arte contemporânea, ganha lugar de destaque condensando os dois sentidos (ver o livro de André Rouillé sobre o percurso da fotografia desde sua invenção até suas diversas utilizações na atualidade), condensando os dois sentidos.

Entrando num riacho, o Rio da Lua, pé ante pé, a água fria. Olho as pedras no chão procurando alguma que brilhe para dar de presente. Uma senhora passa ao meu lado. Seguro seu braço e digo: cuidado. Apontando para o fundo do rio, tento localizar a cabeça da cobra. É uma cobra ali, não é? Ela não vê. Começo a descrever as pedras para tentar lhe mostrar qual é a cabeça da cobra em meio a todas aquelas pedras. Ela me agradece por ter avisado, mas logo sai nadando, me tomando por louco. Fico pa- 
rado, olhando a pedra. Agora já sabia uma pedra, mas a imagem continua sendo a de uma cobra. Olhava para a pedra e via uma perfeita cabeça de cobra, mesmo que soubesse, pela senhora e outros que apareceram, ser uma pedra. 


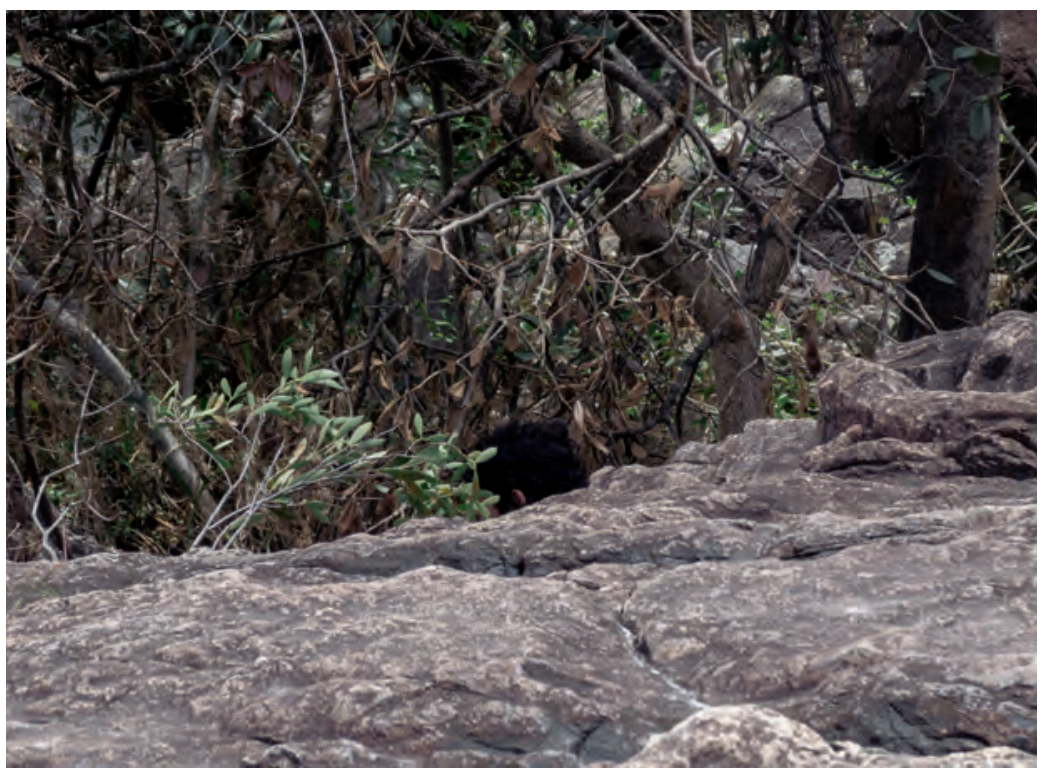




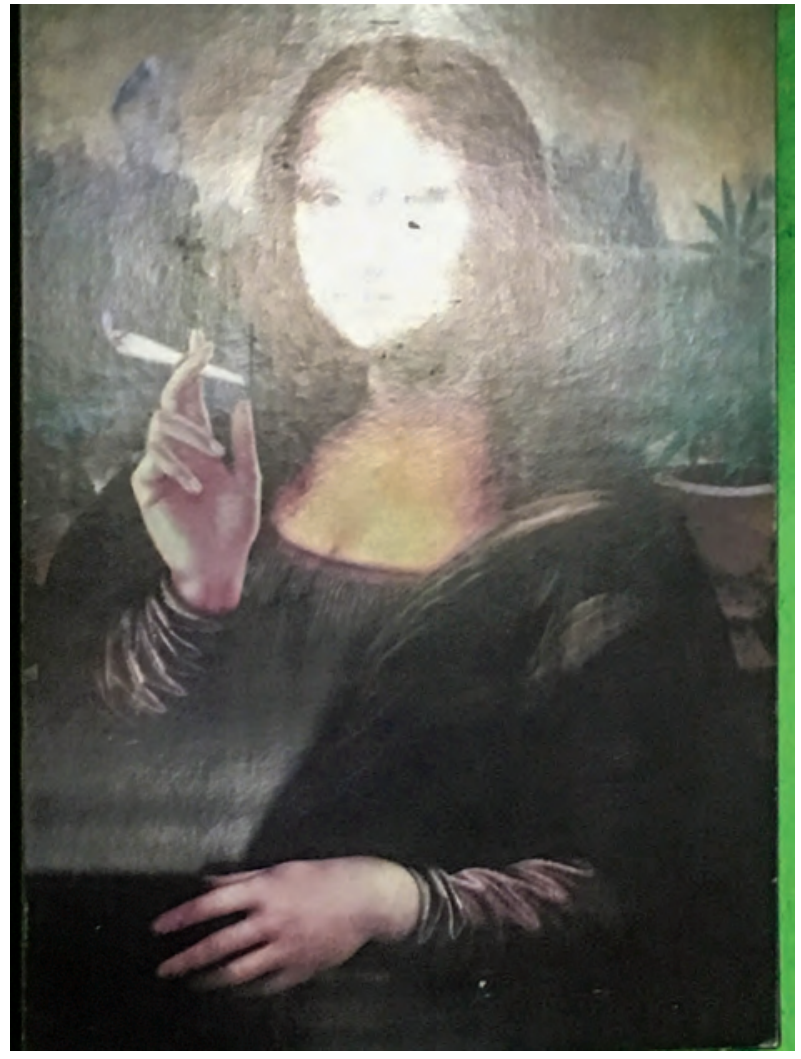




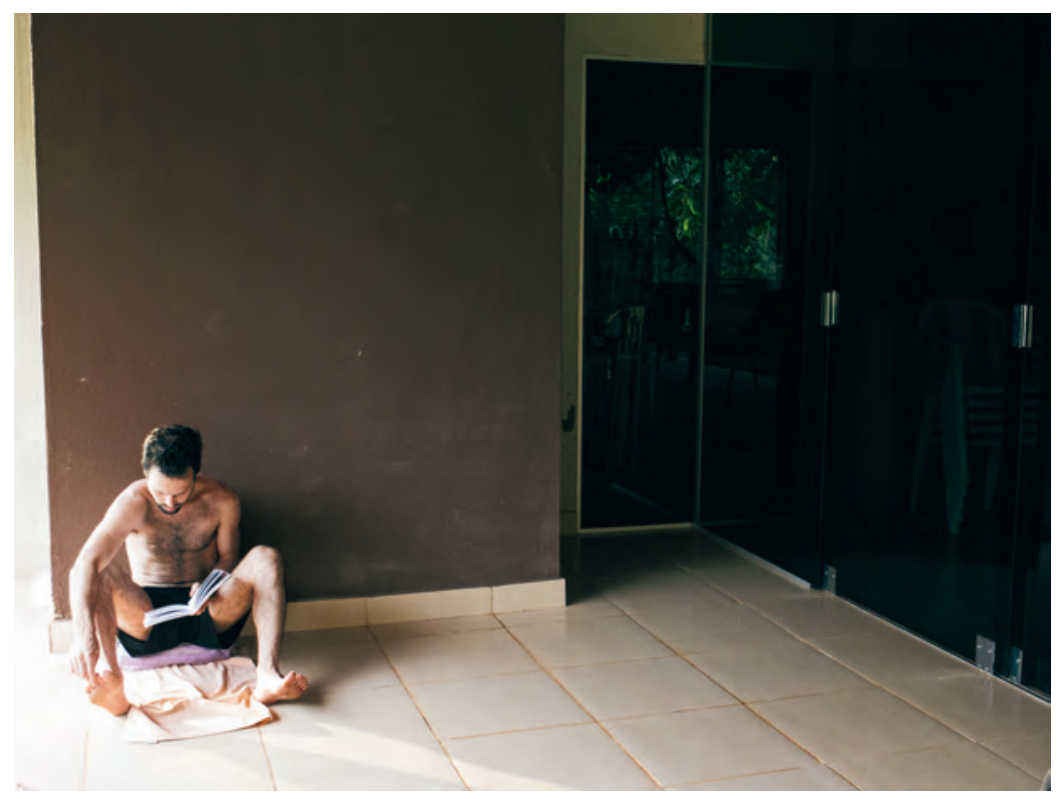




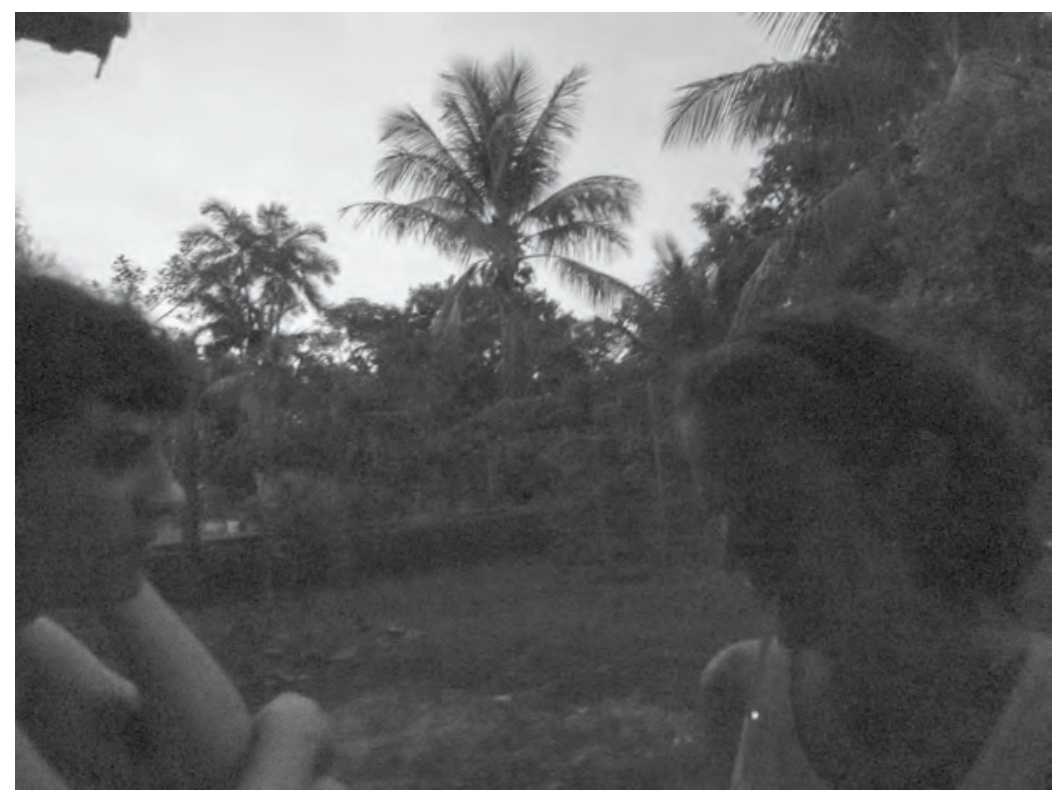




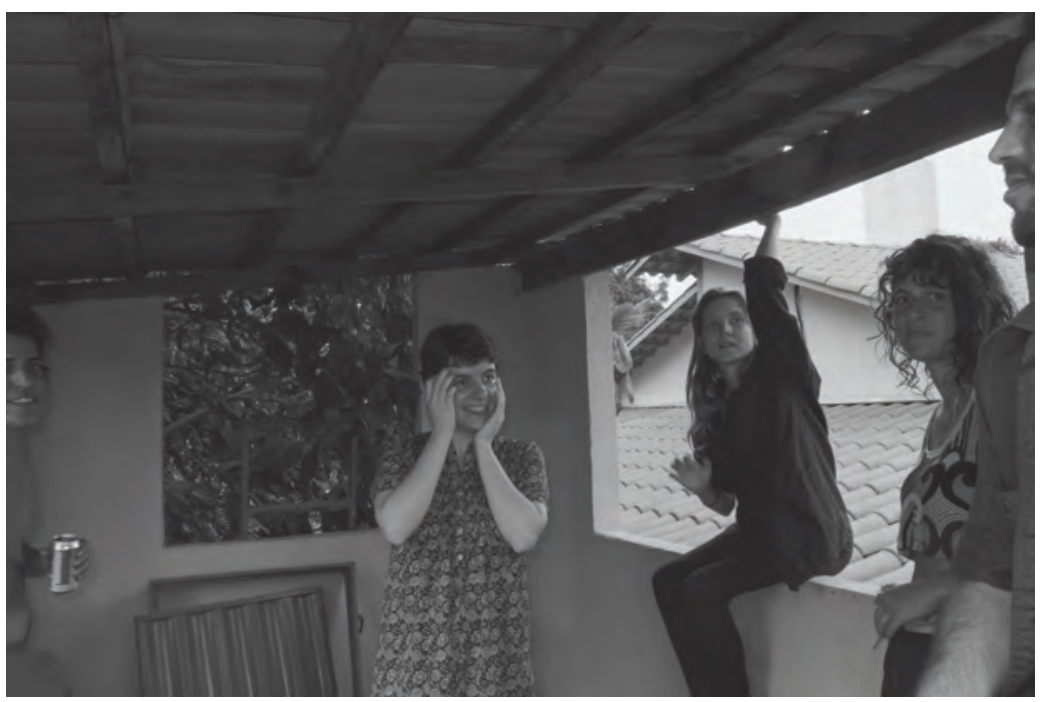




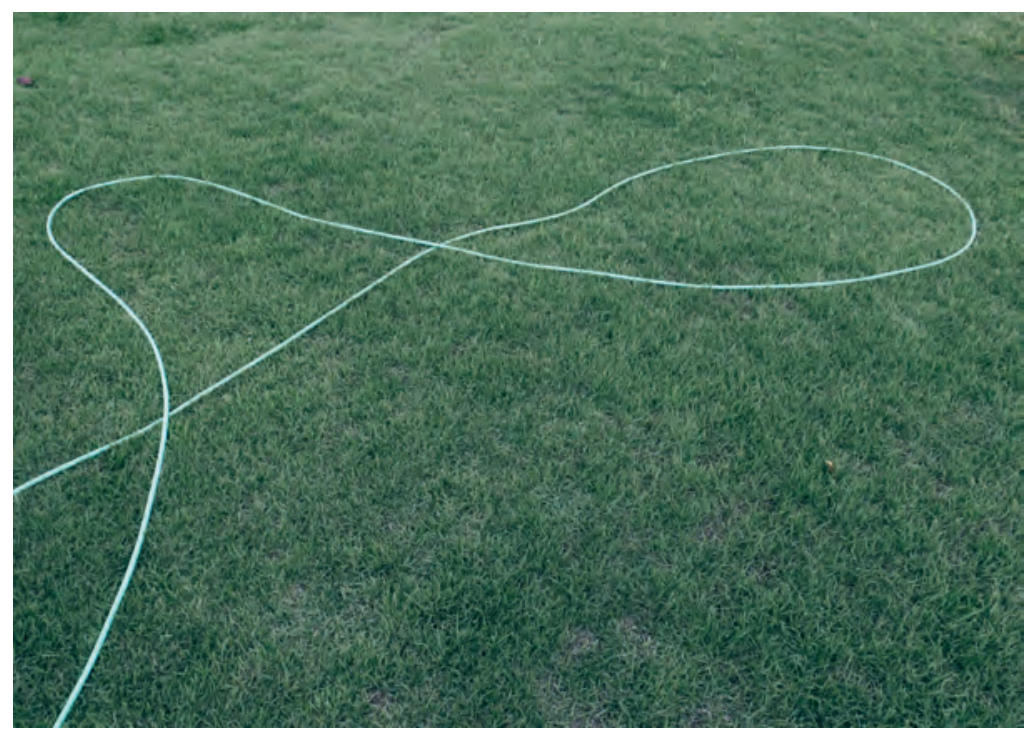




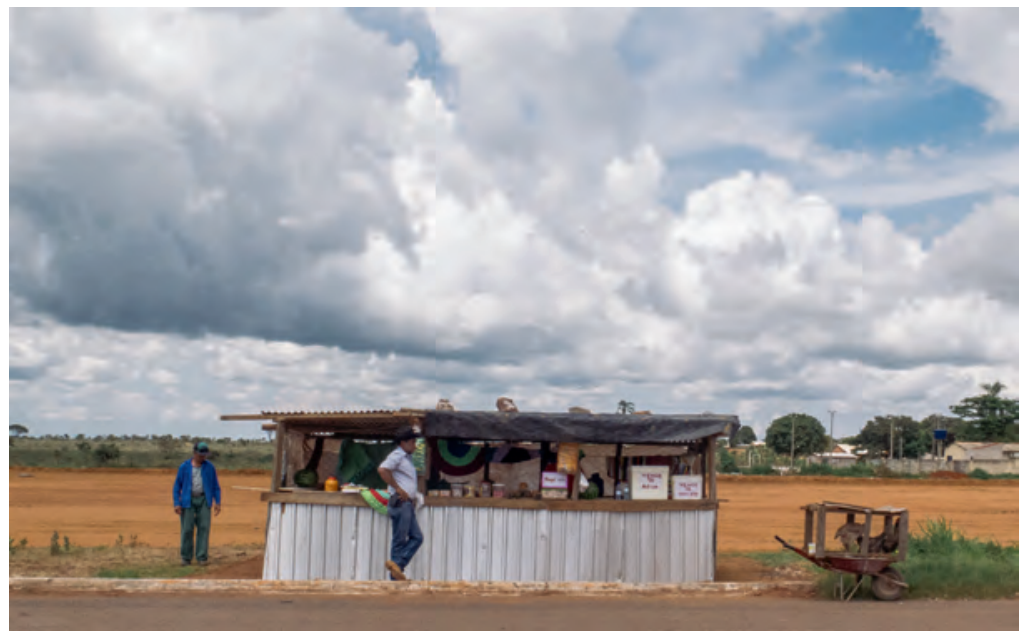




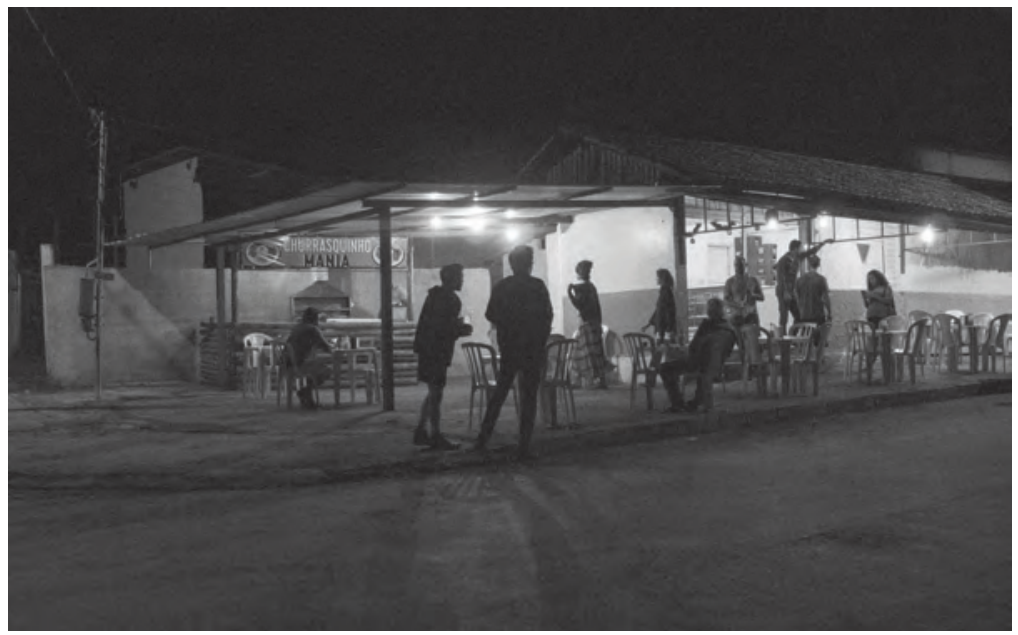




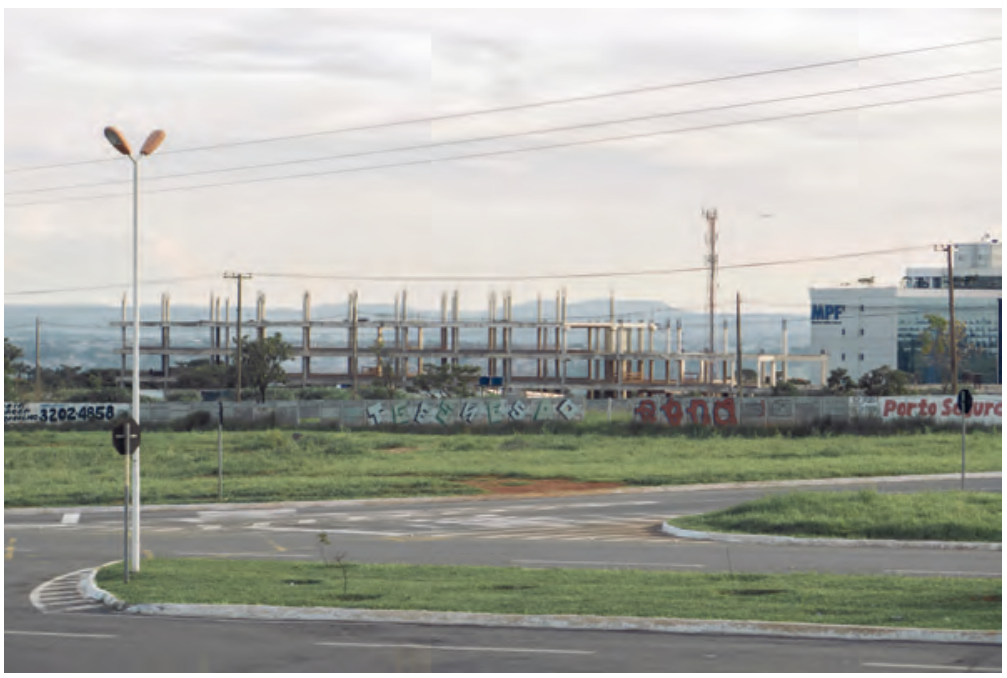




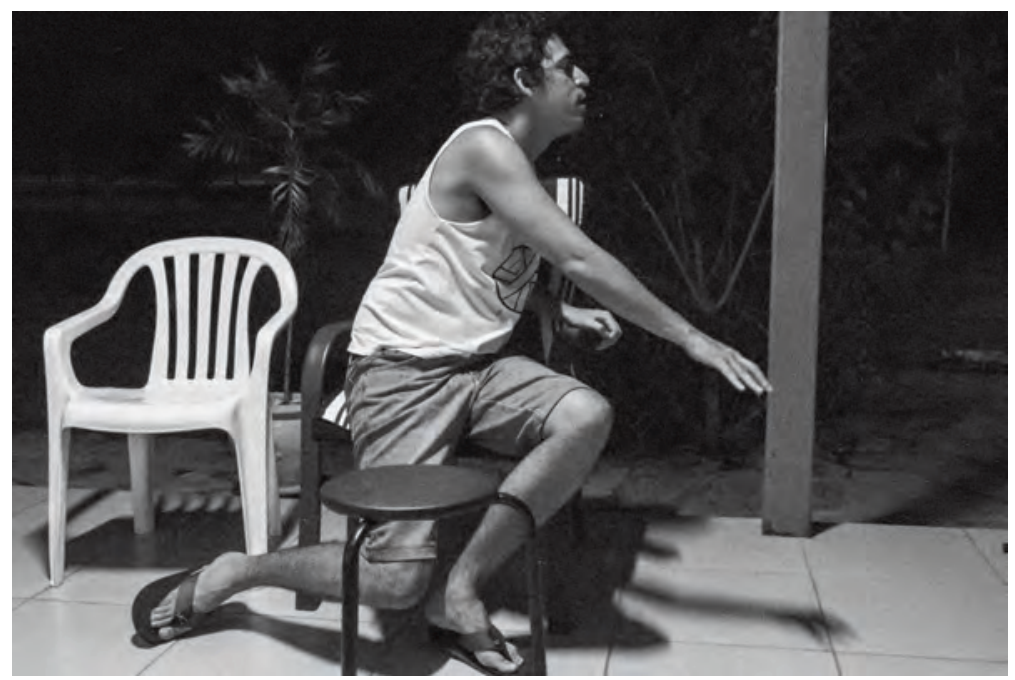




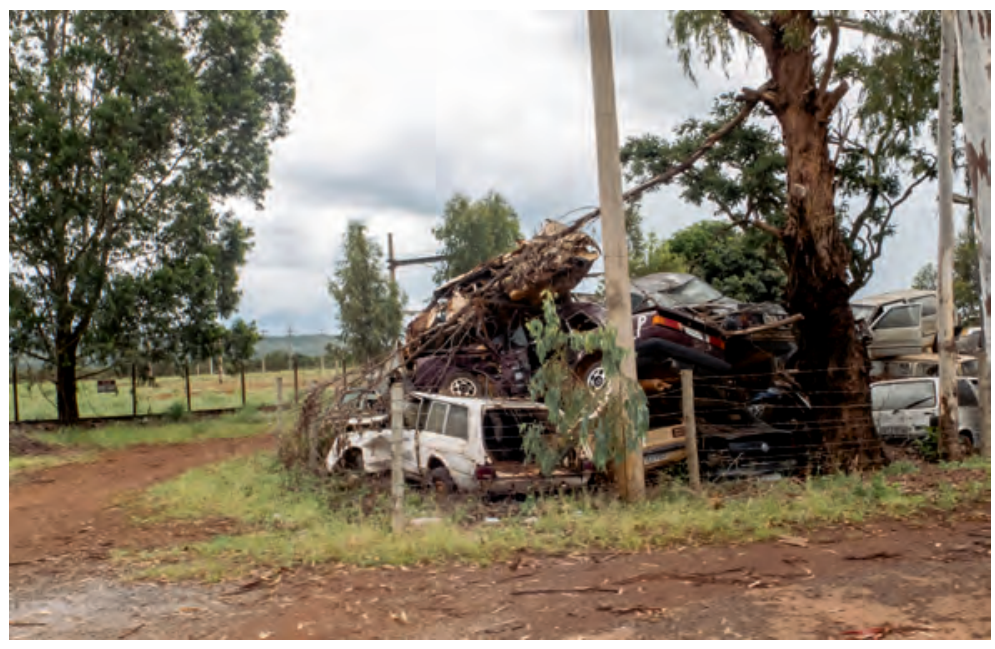




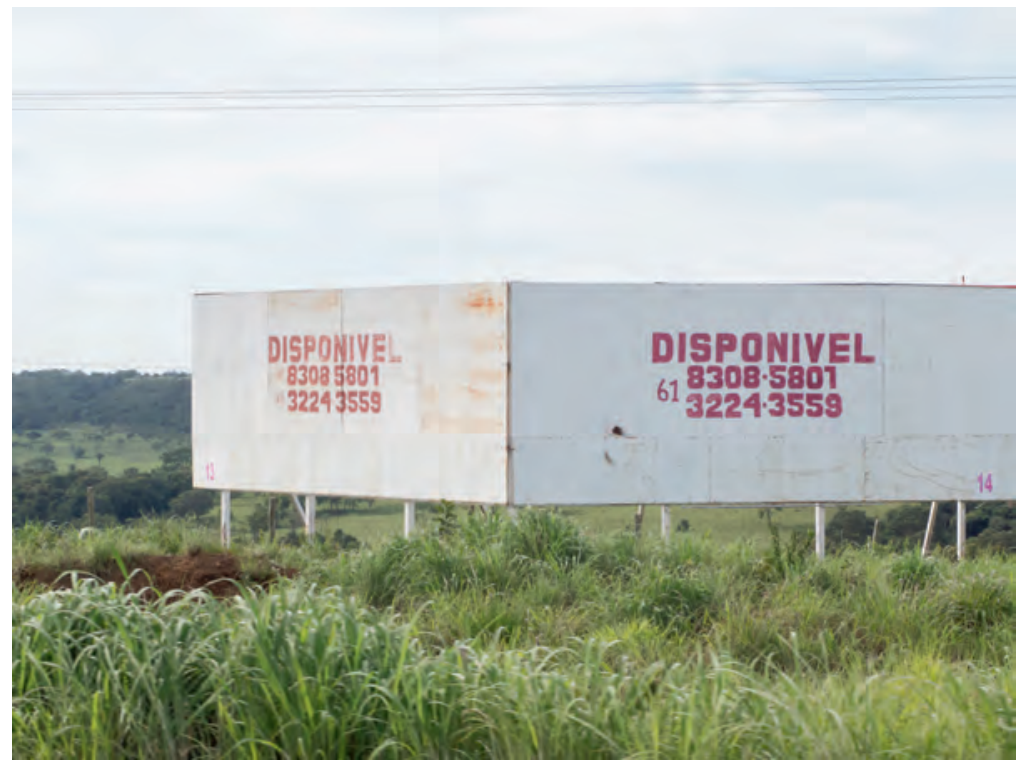




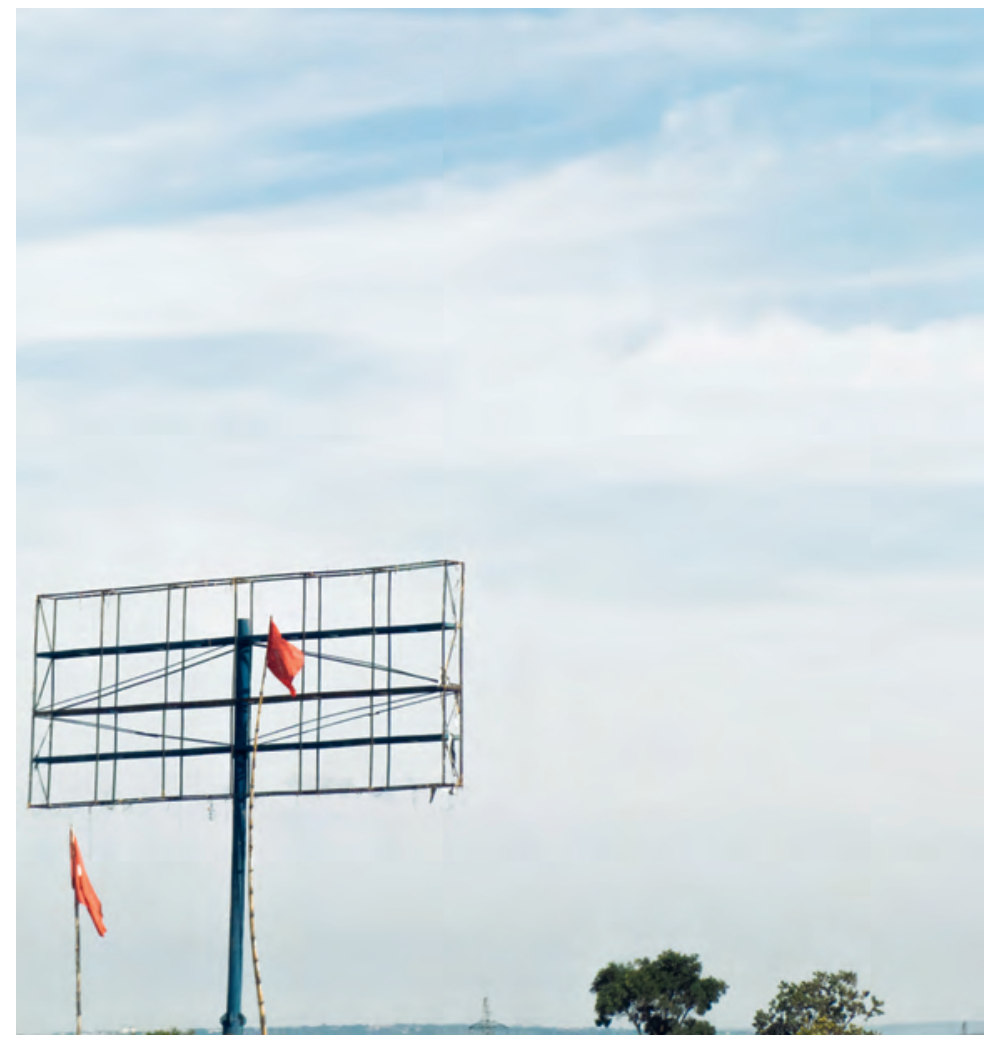




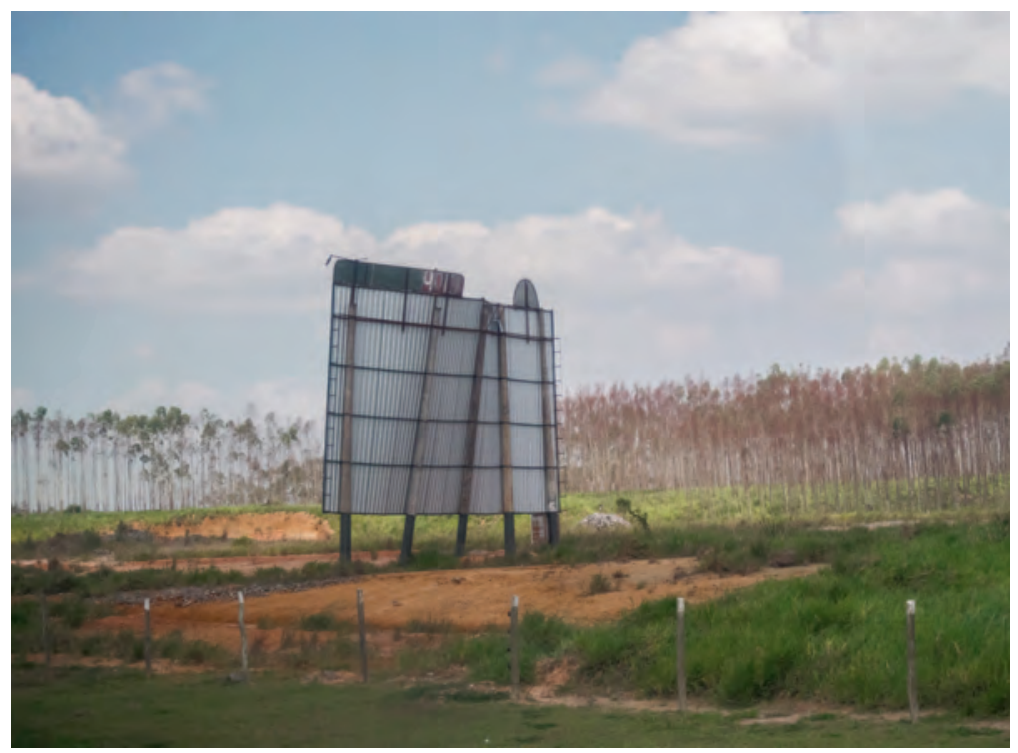




\section{Agradecimentos:}

Nina Guedes, Elcio Basilio, Lucas Campacci, Rafael Moura, Renata Passos, Flávia Ocananza, ao Grupo de pesquisa e impressão fotográfica, aos professores e demais funcionários do departamento e das matérias cursadas ao longo do mestrado, Fernanda Morse, Filipe Massumi, Giovanna Langone, Carol Sinhorelli, Andrea Nunes, Caue Teles, Jacques Eskinazi, Yan Eskinazi, Esther Eskinazi, Hamilton Vieira, Beto Guedes, Catherine Halévy, Julio Ribeiro, Marcelo Hein, Pedro Andrada, Andrey Lupion e Luiz Renato Vieira. 
Dissertação de mestrado apresentada como conclusão de mestrado no programa de pós-graduação em Poéticas visuais, Escola de comunicações e artes, Universidade de São Paulo.

Orientação:

Prof. Dr. João Luiz Musa

Revisão de texto:

Joana Fontana e Márcia Cristina Soares Augusto Vieira Eskinazi Impressão:

Ipsis

Encadernação:

Rosana Chat

Observação:

No ensaio Branco de Sol há diversas fotografias de Nina Guedes.

O presente trabalho foi realizado com apoio da Coordenação de Aperfeiçoamento de Pessoal de Nível Superior - Brasil (CAPES).

Lucas Eskinazi

2019 


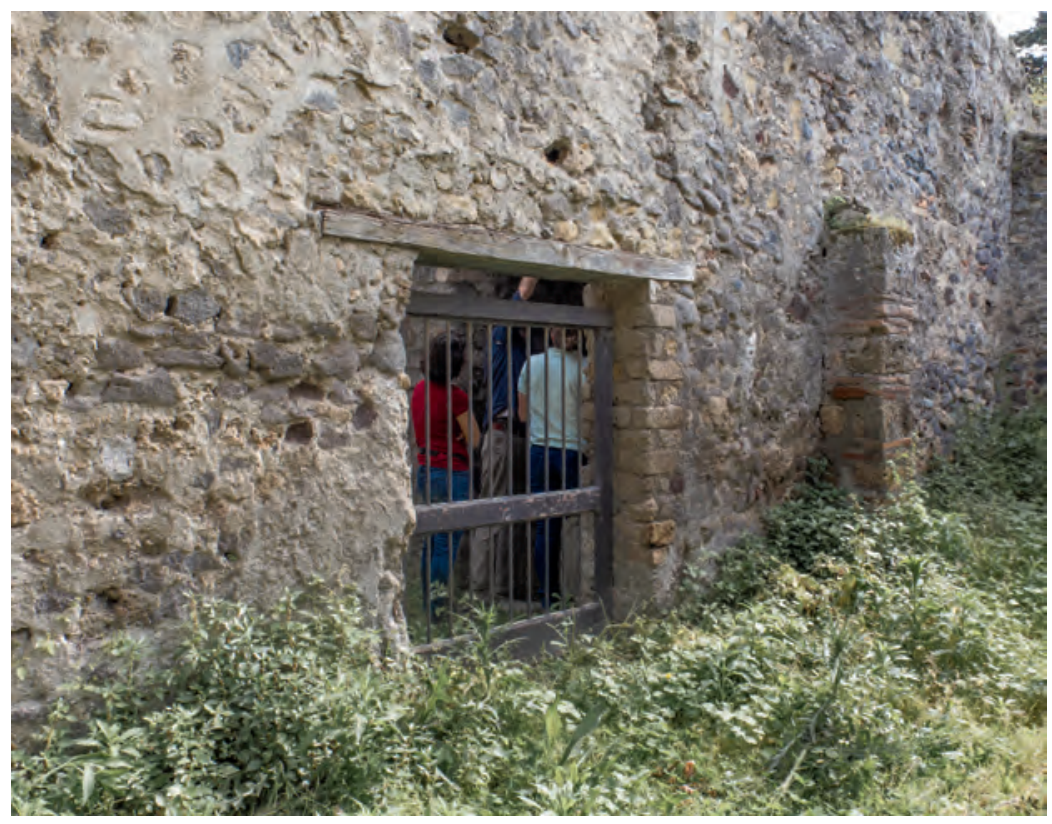

